\title{
How are subaqueous sediment density flows triggered, what is their internal structure and how does it evolve? Direct observations from monitoring of active flows
}

\author{
Peter. J. Talling ${ }^{\text {a,* }}$, Charles K. Paull ${ }^{\mathrm{b}}$, David J.W. Piper ${ }^{\mathrm{c}}$ \\ a National Oceanography Centre, European Way, Southampton SO14 3ZH, UK \\ ${ }^{\mathrm{b}}$ Monterey Bay Aquarium Research Institute, 7700 Sandholt Road, Moss Landing, CA 95039-9644, USA

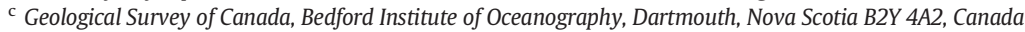

\section{A R T I C L E I N F O}

\section{Article history:}

Received 23 May 2011

Accepted 12 July 2013

Available online 21 July 2013

\section{Keywords:}

Turbidity current

Turbidite

Flow velocity

Sediment concentration

Submarine fan

Sediment density flow

\begin{abstract}
A B S T R A C T
Subaqueous sediment density flows are one of the volumetrically most important processes for moving sediment across our planet, and form the largest sediment accumulations on Earth (submarine fans). They are also arguably the most sparely monitored major sediment transport processes on our planet. Significant advances have been made in documenting their timing and triggers, especially within submarine canyons and delta-fronts, and freshwater lakes and reservoirs, but the sediment concentration of flows that run out beyond the continental slope has never been measured directly. This limited amount of monitoring data contrasts sharply with other major types of sediment flow, such as river systems, and ensure that understanding submarine sediment density flows remains a major challenge for Earth science. The available monitoring data define a series of flow types whose character and deposits differ significantly. Large $\left(>100 \mathrm{~km}^{3}\right)$ failures on the continental slope can generate fast-moving (up to $19 \mathrm{~m} / \mathrm{s}$ ) flows that reach the deep ocean, and deposit thick layers of sand across submarine fans. Even small volume $\left(0.008 \mathrm{~km}^{3}\right)$ canyon head failures can sometimes generate channelised flows that travel at $>5 \mathrm{~m} / \mathrm{s}$ for several hundred kilometres. A single event off SE Taiwan shows that river floods can generate powerful flows that reach the deep ocean, in this case triggered by failure of recently deposited sediment in the canyon head. Direct monitoring evidence of powerful oceanic flows produced by plunging hyperpycnal flood water is lacking, although this process has produced shorter and weaker oceanic flows. Numerous flows can occur each year on river-fed delta fronts, where they can generate up-slope migrating crescentic bedforms. These flows tend to occur during the flood season, but are not necessarily associated with individual flood discharge peaks, suggesting that they are often triggered by delta-front slope failures. Powerful flows occur several times each year in canyons fed by sand from the shelf, associated with strong wave action. These flows can also generate up-slope migrating crescentic bedforms that most likely originate due to retrogressive breaching associated with a dense near-bed layer of sediment. Expanded dilute flows that are supercritical and fully turbulent are also triggered by wave action in canyons. Sediment density flows in lakes and reservoirs generated by plunging river flood water have been monitored in much greater detail. They are typically very dilute $(<0.01 \mathrm{vol} . \%$ sediment $)$ and travel at $<50 \mathrm{~cm} / \mathrm{s}$, and are prone to generating interflows within the density stratified freshwater. A key objective for future work is to develop measurement techniques for seeing through overlying dilute clouds of sediment, to determine whether dense near-bed layers are present. There is also a need to combine monitoring of flows with detailed analyses of flow deposits, in order to understand how flows are recorded in the rock record. Finally, a source-to-sink approach is needed because the character of submarine flows can change significantly along their flow path.
\end{abstract}

(c) 2013 Elsevier B.V. All rights reserved.

\section{Contents}

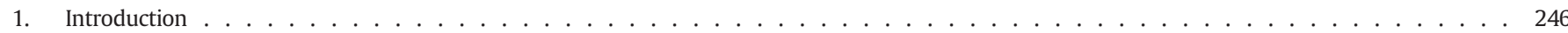

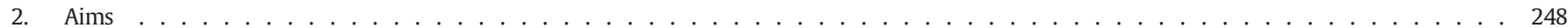

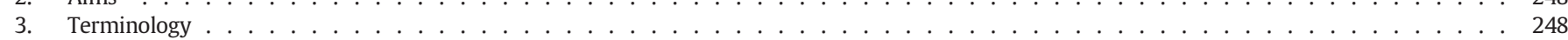

4. Monitoring data from the oceans . . . . . . . . . . . . . . . . . . . . . . . . . . . . . . . . . . 248

\footnotetext{
* Corresponding author. Tel.: +443581666 .

E-mail address: Peter.Talling@noc.soton.ac.uk (P.J. Talling).
} 
4.1. Flows triggered by slope-failure associated with earthquakes ． . . . . . . . . . . . . . . . . . . . . . . . . 248

4.1.1. Grand Banks, offshore Newfoundland, $1929 \ldots \ldots \ldots$. . . . . . . . . . . . . . . . . . . . . . . . . . . . . . 248

4.1.2. Offshore Taiwan, Pingtung earthquakes, $2006 \ldots \ldots \ldots \ldots$

4.1.3. Algerian margin, western Mediterranean, 1954, 1980, 2003 . . . . . . . . . . . . . . . . . . . . . . . . . . . 253

4.1.4. Tokachi-oki earthquake, offshore Japan, $2003 \ldots \ldots \ldots$

4.1.5. Offshore Sagami Bay, Japan, 1997, 1998, and $2006 \ldots \ldots \ldots$

4.1.6. Cariaco Basin, $1997 \ldots \ldots \ldots \ldots \ldots$

4.2. Flows triggered by canyon-head slope-failures unrelated to earthquakes ． . . . . . . . . . . . . . . . . . . . . . . . . . 255

4.2.1. Var Canyon, Mediterranean, 1979 "Nice Airport" event . . . . . . . . . . . . . . . . . . . . . . . . . . . . . . . . . . . . . . . 255

4.2.2. Gioia Canyon, offshore Calabria, Italy, 1977 . . . . . . . . . . . . . . . . . . . . . . . . . . . . . . . . . . . 257

4.3. Flows associated mainly with strong wave action . . . . . . . . . . . . . . . . . . . . . . . . . . . 257

4.3.1. Monterey Canyon, offshore California . . . . . . . . . . . . . . . . . . . . . . . . . 257

4.3.2. Scripps and La Jolla Canyons, offshore California $\ldots \ldots \ldots \ldots$

4.3.3. Hueneme and Mugu Canyons, offshore California . . . . . . . . . . . . . . . . . . . . . . . . . 262

4.3.4. Eel Canyon, offshore California . . . . . . . . . . . . . . . . . . . . . . . . . . . . 262

4.3.5. Nazaré Canyon, offshore Portugal _. . . . . . . . . . . . . . . . . . . . . . . . . . . . . . 262

4.3.6. Hurricane Iwa, offshore Oahu, Hawaii, $1982 \ldots \ldots \ldots$

4.4. Flows in systems associated with rivers . . . . . . . . . . . . . . . . . . . . . . . . . . . 262

4.4.1. Zaire Canyon-channel system, West Africa, 2001, 2004 \& 2009-10 ～. . . . . . . . . . . . . . . . . . . . . . . . . . 262

4.4.2. Typhoon Morakot, Taiwan, $2009 \ldots \ldots \ldots \ldots$

4.4.3. Typhoon Kalmaegi, Taiwan, 2008 . . . . . . . . . . . . . . . . . . . . . . . . . . . . . . . . . . . 264

4.4.4. Cable breaks off rivers that discharge directly into a canyon . . . . . . . . . . . . . . . . . . . . . . . . . . . . . . . . . . . . . . . . . . . . . . .

4.4.5. Var Canyon, Mediterranean, 2005-2010 _ . . . . . . . . . . . . . . . . . . . . . . . . . . . . 264

4.4.6. Bute Inlet, British Columbia, Canada, 1985-86, 1988-89, and 2008-10 . . . . . . . . . . . . . . . . . . . . . . . . . . 265

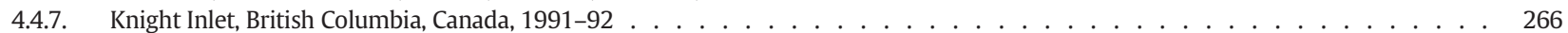

4.4.8. Squamish River delta, Canada, 2004-12 . . . . . . . . . . . . . . . . . . . . . . . . . . . . . 266

4.4.9. Fraser River delta, Canada, $1994-2012 \ldots \ldots \ldots$

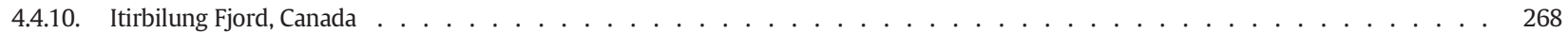

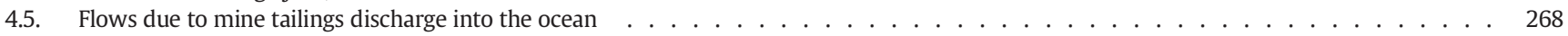

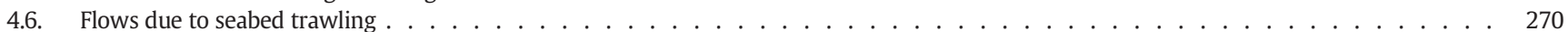

5. Monitoring data from lakes and reservoirs . . . . . . . . . . . . . . . . . . . . . . . . . . . . . . . . 271

5.1. Density flows generated directly by river flood discharge . . . . . . . . . . . . . . . . . . . . . . . . . . 271

5.1.1. Flood input conditions . . . . . . . . . . . . . . . . . . . . . . . . . . . . . . . . . . . . . . . . . . . 271

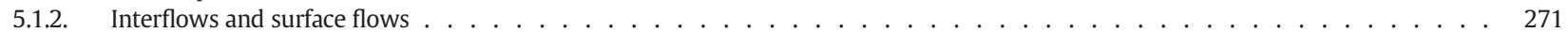

5.1.3. Sediment concentration in basin-floor density flows . . . . . . . . . . . . . . . . . . . . . . . . . . . . . . . . 271

5.1.4. Density flow velocities . . . . . . . . . . . . . . . . . . . . . . . . . . . 271

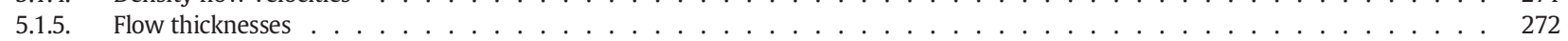

5.1.6. Run out length . . . . . . . . . . . . . . . . . . . . . . . . . . . . . . . . 272

5.1.7. Flow duration and frequency . . . . . . . . . . . . . . . . . . . . . . . . . . . . 272

5.1.8. Size of suspended sediment . . . . . . . . . . . . . . . . . . . . . . . . . . . . . . . . . . . . 272

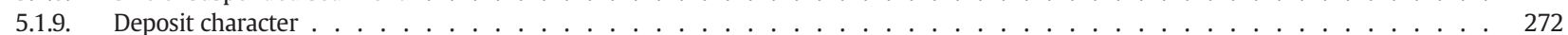

5.2. Fast flows in lakes - not generated directly by flood discharge . . . . . . . . . . . . . . . . . . . . . 275

5.3. Density flows generated by mine tailings discharge in lakes . . . . . . . . . . . . . . . . . . . . . . . . 275

6. Non-particulate density currents . . . . . . . . . . . . . . . . . . . . . . . . . . . . . . . 275

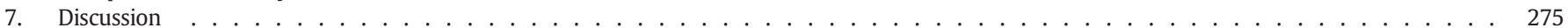

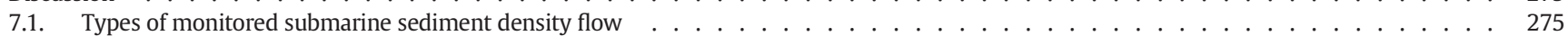

7.1.1. Long run-out, powerful flows that reach submarine fans . . . . . . . . . . . . . . . . . . . . . . 275

7.1.2. Canyon-confined flows mainly associated with strong wave action $\ldots \ldots \ldots$

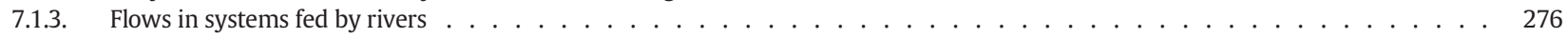

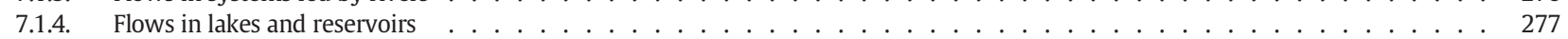

7.2. Quantitative analysis of measured parameters . . . . . . . . . . . . . . . . . . . . . . . . . 277

7.2.1. Dilute flows in lakes and reservoirs . . . . . . . . . . . . . . . . . . . . . . . . . . . . . . . 277

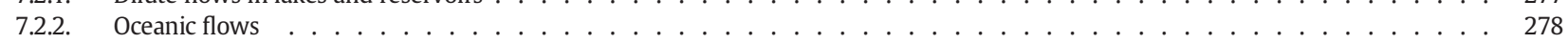

7.3. Turbidity currents: the most poorly monitored major transport process on Earth． . . . . . . . . . . . . . . . . . . . . . . . 281

7.3.1. Turbidity currents in lakes and reservoirs . . . . . . . . . . . . . . . . . . . . . . . . . . . . . . . . . 281

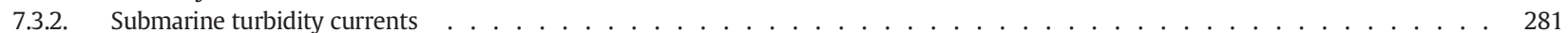

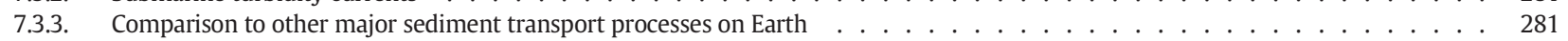

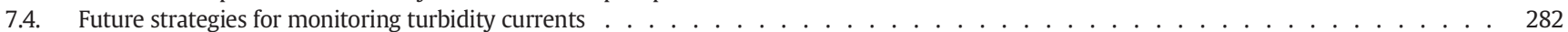

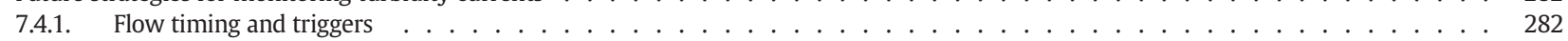

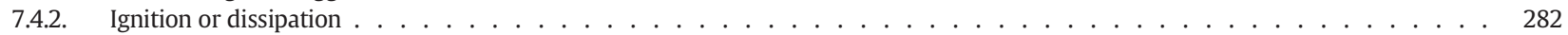

7.4.3. Flow character . . . . . . . . . . . . . . . . . . . . . . . . . . . . . . . 282

7.4.4. Complex spatial evolution of flow character . . . . . . . . . . . . . . . . . . . . . . . . . 282

7.4.5. Diversity of flow types and choice of monitoring locations $\ldots \ldots \ldots$

7.4.6. Limitation of monitoring data from very dilute flows in lakes and reservoirs . . . . . . . . . . . . . . . . . . . . . . . 283

7.4.7. The need for coupling of flow monitoring data to studies of the flow deposit . . . . . . . . . . . . . . . . . . . . . . .

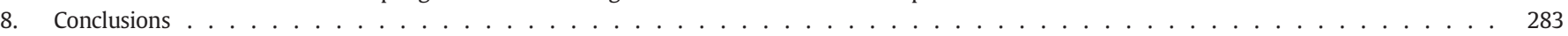

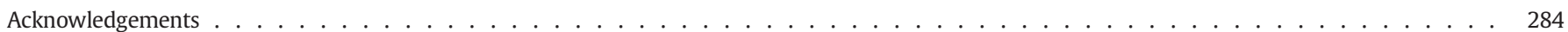

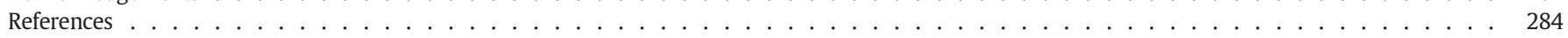




\section{Introduction}

Underwater flows of sediment, driven by the excess density provided by their sediment load, are one of the most important process for moving sediment across our planet. They dominate sediment transport in many parts of the deep oceans, freshwater lakes, and reservoirs. We need to understand these flows, if we are to understand how sediment is being redistributed on Earth.

Submarine flows produce the most extensive sediment accumulations on our planet, called submarine fans. The Bengal submarine fan, for instance, extends for $2000 \mathrm{~km}$ from the mouth of the Ganges and Brahmaputra Rivers to beyond the southern tip of the Indian subcontinent. The scale of individual submarine flows can also be exceptionally large. A single flow can transport over $100 \mathrm{~km}^{3}$ of sediment, or more than ten times the combined annual sediment load from all of the world's rivers (Talling et al., 2007a). They include the longest run-out sediment density flows yet documented on Earth, and sometimes travel for several thousand kilometres (Talling et al., 2007a). Such long run out can be achieved whilst travelling across extremely low sea floor gradients of less than $0.1^{\circ}$, and sometimes $<0.05^{\circ}$. Flow speeds can exceed $19 \mathrm{~m} / \mathrm{s}$, and be sustained at 3 to $10 \mathrm{~m} / \mathrm{s}$ on gradients of just $0.2^{\circ}$ to $0.3^{\circ}$ (Piper et al., 1988). Submarine sediment density flows often build extensive channels (Weber et al., 1997), but in some cases prodigious run out distances are achieved without channel-confinement, by flows that were 200 to 300 km wide (Fig. 1; Piper et al., 1988; Talling et al., 2007a). For comparison, the Amazon River is $\sim 10 \mathrm{~km}$ wide as it reaches the sea.

The deposits of ancient submarine flows form thick sequences in the rock record (Talling et al., 2012a), which now hold many of our largest subsurface oil and gas reserves (Nielsen et al., 2007). Predicting the location, shape and extent of these deposits is important for effectively recovering these reserves. Active flows are a hazard to sea floor infrastructure and communication cables (Barley, 1999; Hsu et al., 2008). This includes infrastructure used to recover the offshore oil and gas reserves, which can cost several tens to hundreds of millions of dollars. Fast moving flows can damage sea floor telecommunication cables that carry more than $95 \%$ of transoceanic information, including the internet and financial markets (Carter et al., 2009). These flows therefore have significant economic and strategic importance.

Submarine density flow deposits may contain large volumes of terrestrial and marine organic carbon, and play a role in modulating rates of organic carbon burial in the deep ocean and therefore potentially $p \mathrm{CO}_{2}$ levels in the atmosphere (Galy et al., 2007). Flows generated by large underwater landslides record the frequency and emplacement dynamics of these landslides, which are key parameters for predicting the magnitude of risk from associated tsunamis. Flow deposits may provide a detailed record of major earthquakes, which extends further back in time than most records on land (Goldfinger et al., 2007; Atwater and Griggs, 2012), of the way in which submarine landslides are emplaced which has important implications for tsunami-genesis (Wynn and Masson, 2003; Hunt et al., 2011), and of mega-floods associated with glacial melting that are inferred to have caused abrupt global climatic change (Piper and Normark, 2009). Obtaining a clearer understanding of submarine flow processes is of both scientific interest and societal relevance.

Turbidity currents were first documented in lakes by FrançoisAlphonse Forel, who studied the Rhone Delta in Lake Geneva (Forel, $1885,1895)$. He proposed that a prominent channel on the lake floor was formed by sediment deposition from underwater flows generated by sinking river water (Forel, 1895; and see Girardclos et al., 2012). The relative importance of hyperpycnal river discharge, or other processes such as delta-front slope failure, for triggering turbidity currents remains a key question for this contribution. Sediment density flows play an important role in the dispersal of sediment within freshwater lakes (Lambert and Hsu, 1979; Gilbert et al., 2006; Crookshanks and Gilbert, 2008), and lacustrine turbidites can form hydrocarbon reservoirs (Feng et al., 2010). These flows can also play an important part in the delivery of organic matter and nutrients within lakes (De Cesare et al., 2006). Lakes are often strongly thermally stratified, so that dilute sediment density flows form interflows within the lake, as well as along the lake floor and lake surface (Pharo and Carmack, 1979; Fernandez and Imberger, 2008; Marti et al., 2011). These flows may contribute to mixing within the lake, or larger scale circulation (De Cesare et al., 2006). Turbidity currents within lakes can provide a record of changes in flood frequency and magnitude, and hence climatic change (Lambert and Hsu, 1979; Gilbert et al., 2006). They can also provide a record of major landslides that can potentially generate hazardous tsunami, especially in lakes whose shores are densely populated (Girardclos et al., 2007; Kremer et al., 2012). Lacustrine turbidites can also potentially provide a valuable record of major earthquakes (Monecke et al., 2004; Strasser et al., 2011).

Turbidity currents can play an important role in the management and initial design of reservoirs (Chikita, 1989, 1990; Fan and Morris, 1992; Umeda et al., 2000, 2006; De Cesare et al., 2001). Sediment deposition by turbidity currents affects their storage capacity, which can have significant strategic importance in locations affected by rapid siltation, such as the large reservoirs along the Yellow River in China (Hu et al., 2012; Wei et al., 2013). Turbidity current deposition can also impair navigation and block intake structures, whilst flushing of sediment can impact locations further downstream (Fan and Morris, 1992; De Cesare et al., 2001).

Monitoring of turbidity currents is often easier and less expensive to undertake in lakes and reservoirs than in most oceanic settings. This is due to the shallower water depths in lakes and reservoirs (necessitating smaller vessels), and the relatively short run-out distances of flows. Slow moving (typically $<0.5 \mathrm{~m} / \mathrm{s}$ ) and dilute $(<0.01$ vol.\%) sediment flows associated with river floods have therefore been monitored in considerable detail in lakes and reservoirs. However, a key question that is addressed here is the extent to which these dilute and slow flows in freshwater can serve as analogues for oceanic turbidity currents, especially longer run- or faster moving oceanic turbidity currents.

Submarine sediment density flows can be very difficult to monitor directly, for several reasons. First, the flows occur in a relatively inaccessible location on the sea floor. Submarine flows are therefore expensive to monitor, especially if they occur in deep water (such that large research vessels are needed), cover large areas of the sea floor, or multiple deployments of remotely operated vehicles (ROVs) are needed to place and recover monitoring equipment. Second, flows are relatively infrequent in most locations worldwide, and so it is difficult to predict when a flow might occur. However, as described by this contribution, there are locations where flows occur frequently over time-scales of several months to several years. Such frequent flows tend to have short runout distances, although there are exceptions (Khripounoff et al., 2003; Hsu et al., 2008; Vangriesheim et al., 2009; Carter et al., 2012; Cooper et al., 2013). Third, and perhaps most importantly, submarine flows have a record of damaging or destroying the instruments or moorings placed in their path. Finally, it is especially difficult to image within flows (or layers within flows) that have high sediment concentrations, although novel sensors are being developed. This ensures that there is more information from weaker and lower concentration flows.

It is important to compare the amount and quality of direct monitoring observations from different types of submarine and freshwater sediment density flows, with that from the other major sediment transport processes on Earth. This allows us to address the fundamental question; how well do we understand subaqueous sediment density flows in comparison to other transport process? Significant advances have been made in monitoring currents in submarine canyons, over timescales of several years. This monitoring includes weak flows that infill the canyons, as well as tidal currents and nepheloid layers (Puig et al., 2003; de Stiger et al., 2007; Martin et al., 2011). Detailed repeated mapping and monitoring of submarine delta-front systems in Canada has produced important contributions (Prior et al., 1987; Bornhold et al., 1994; Hill, 2012; Hughes Clarke et al., 2012, in press). Co-ordinated large-scale field experiments have advanced our understanding of cross-shelf dispersal of 


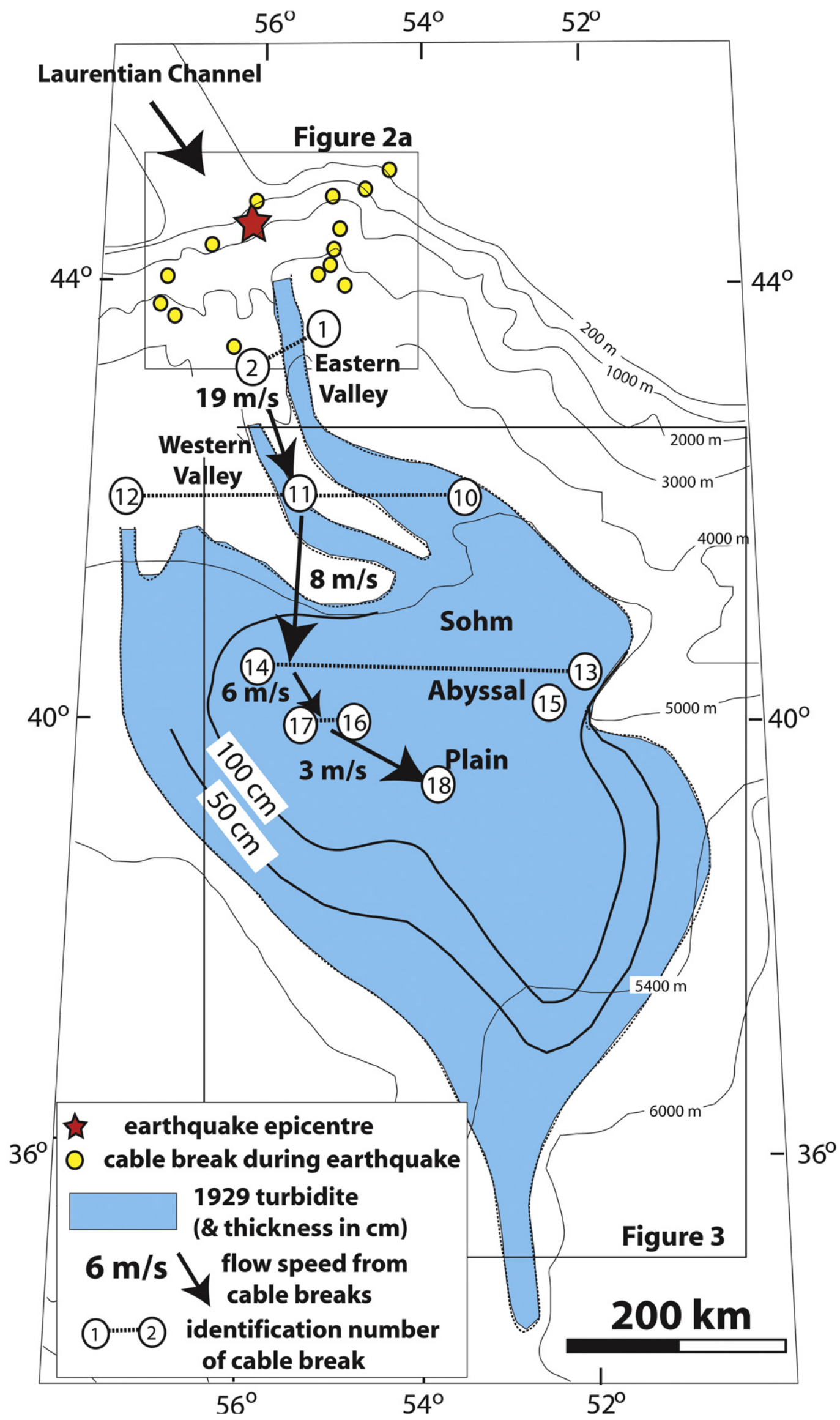

Fig. 1. Map summarising the 1929 Grand Banks event that shows the location of numbered cable breaks, flow speeds calculated from cable breaks, epicentre of the $\mathrm{M}_{\mathrm{W}} 7.2$ earthquake, and isopachs of the resulting turbidite from Piper and Aksu (1987) based on the small number of available cores (Fig. 3A). 
sediment by gravity flows in which sediment is mainly resuspended by wave or tidal action (Sternberg et al., 1996; Ogston et al., 2000; Traykovski et al., 2000, 2007; Wright et al., 2001; Wright and Friedrichs, 2006; Palanques et al., 2009) or transported off the shelf by dense water cascades (Canals et al., 2006). However, monitoring observations are yet to capture the powerful sediment flows that cut and flush sediment beyond submarine canyons in any detail. Remarkably, the sediment concentration of submarine turbidity currents that reach beyond the continental slope has never been measured directly. These are the largest volume turbidity currents, which form most of the rock record and subsurface hydrocarbon reservoirs.

Observations from monitoring are of two types; information on the timing (and hence by inference triggers) of the flow, and information on their internal character (such as velocity, sediment concentration and thickness) and how it evolves along the flow path. It is generally easier to document the timing and triggers of flows, than it is to document their internal character. This difference in the quality of information on flow triggers and flow character is apparent throughout this review. It is the reason that flows are subdivided primarily according to their triggers.

Our understanding of turbidity currents is based heavily on the analysis of their deposits, together with results from small-scale laboratory experiments or numerical models. It is often very difficult (or impossible) to infer unambiguously the character of a sediment flow from its deposit alone, as different processes can form similar deposits (Talling et al., 2012a). Processes that occur in laboratory flows may differ significantly from those in full-scale turbidity currents, due to scaling issues and input conditions. There is a need to understand the basic character of sediment density flows (such as whether they are dilute or dense) before a numerical model can be formulated that accurately captures their behaviour. The monitoring data summarised here is therefore particularly valuable, as the observations come directly from the full-scale flows in action. Further direct monitoring of active flows is arguably the most obvious way of achieving step changes in our understanding of turbidity currents. It is hoped that this contribution will encourage a wide range of direct monitoring studies in the future.

\section{Aims}

The initial aim is to summarise direct monitoring observations from key field studies for submarine sediment density flows (Section 4; Table 1) and flows in freshwater lakes and reservoirs (Section 5; Table 2). This synthesis of direct monitoring observations is timely because it is over 35 years since the last review (Inman et al., 1976).

The second aim is to use these field data to define a series of generalised and simplified models for different types of sediment density flow. This classification subdivides flows initially according to how they are triggered, and then according to their setting (freshwater or marine; canyon or open slope) and relative power or run-out distance. This classification aims to capture and convey the considerable variability seen in subaqueous sediment density flow character.

The third aim is to use parameters that have been measured, firstly within lakes and reservoirs and then within submarine flows, to quantitatively analyse flow character and behaviour. This section starts with a review of the types of measurements that are available, as this determines which types of quantitative analyses are possible. The section concludes by assessing whether sediment density flows either tend to erode and accelerate (ignite), or deposit and decelerate (dissipate; Parker, 1982).

The fourth aim is to compare briefly the amount and quality of information available for different types of sediment density flow, and other major sediment transport processes on earth. This section assesses whether long run-out submarine sediment density flows are the most sparsely monitored major sediment transport process on our planet.

The final aim is to outline effective future strategies for monitoring sediment density flows, and highlight the key technological or scientific issues that still need to be addressed.

\section{Terminology}

Here we follow the terminology of Talling et al. (2012a). The term sediment density flow is used to denote an overall flow event driven by the excess density of the sediment that it contains. A single sediment density flow can comprise several different flow types, including turbidity current and debris flow. Transformation may occur between these different flow types as the sediment density flow evolves. Turbidity currents are fully turbulent and sediment is supported primarily by fluid turbulence, although turbulence may be damped within nearbed layers that characterise high density turbidity currents. Turbidity currents form deposits (turbidites) in an incremental layer-by-layer fashion, with segregation of larger and smaller grains. Debris flows are typically laminar or weakly turbulent, and sediment support is mainly through mechanisms other than turbulence (such as cohesive matrix strength or grain-to-grain interactions). Deposition (of debrites) occurs primarily through en-masse consolidation, during which there is little or no size segregation.

This contribution is concerned with density flows driven primarily by excess sediment density, rather than by differences in water density due to temperature or salinity. Only a short section is included on recent advances in understanding of thermohaline density flows, in which differences in water density (rather the excess density of the sediment load) drive the flow. Density flows in which sediment suspension is primarily due to wave or tidal resuspension are also not considered in detail, although there have been major advances in understanding of such wave- or tide-modified flows in recent years (Sternberg et al., 1996; Ogston et al., 2000; Traykovski et al., 2000, 2007; Wright et al., 2001; Wright and Friedrichs, 2006). Sediment transport by tidal flows within canyons (e.g. Xu and Noble, 2009; Xu, 2011), or nepheloid layers (e.g. de Stiger et al., 2007; Liu et al., 2010) are also excluded from this review. There are very few, if any, direct monitoring observations of large-scale subaqueous slumps and slides in action, although this contribution describes repeated bathymetric surveys that document small delta-front failures. Repeat bathymetric surveys have provided recent insights into subaqueous sediment density flows generated by volcanic eruptions (e.g. Trofimovs et al., 2006, 2008; Le Friant et al., 2009, 2010). However, this review only considers direct monitoring of underwater density flows triggered by non-volcanic processes.

\section{Monitoring data from the oceans}

Submarine flows triggered by slope failure are described initially, starting with failures associated with major earthquakes, followed by failures unrelated to earthquakes. Canyon confined flows associated with periods of strong wave action are then described, which are not associated with river flood events. A final section outlines monitoring data from systems fed by rivers, which comprise delta-fronts or canyons linked directly to river mouths. These flows can be triggered by delta front slope failure or by plunging of river flood water.

\subsection{Flows triggered by slope-failure associated with earthquakes}

These flows resulted from slope failure, apparently triggered by earthquakes, and the flows were typically relatively fast moving. The first three events are long run-out events that reached beyond the continental slope.

\subsubsection{Grand Banks, offshore Newfoundland, 1929}

An event that broke a series of sea floor cables in 1929 offshore from the Grand Banks has played a seminal role in our understanding of submarine sediment density flows (Fig. 1). This powerful and long run out flow was triggered by a relatively large $\mathrm{M}_{\mathrm{W}} 7.2$ earthquake that caused partial or almost complete failure across an $250 \mathrm{~km}$ long extent of continental slope (Fig. 2; Piper et al., 1985, 1988, 1999; Mosher and Piper, 2007). The slope failures were relatively shallow (5 
Table 1

Monitoring data from oceanic sediment density flows.

\begin{tabular}{|c|c|c|c|c|c|c|c|c|c|c|c|c|}
\hline 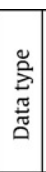 & $\begin{array}{l}\text { Location \& } \\
\text { reference(s) }\end{array}$ & $\begin{array}{l}\text { Triggering } \\
\text { process }\end{array}$ & $\begin{array}{c}\text { Velocity } \\
(\mathrm{m} / \mathrm{s}) \\
\text { (flow front } \\
\text { speeds unless } \\
\text { stated) }\end{array}$ & \begin{tabular}{c|} 
Sediment \\
concen- \\
tration \\
(\% volume) \\
assumes \\
$2600 \mathrm{kgm}^{-3}$ \\
\end{tabular} & $\begin{array}{c}\text { Grain size } \\
\text { suspended } \\
\text { within flow }\end{array}$ & $\begin{array}{c}\text { Flow } \\
\text { thickness } \\
\text { (m) and width } \\
(\mathrm{km})\end{array}$ & $\begin{array}{c}\text { Duration and } \\
\text { run-out time } \\
\text { to final } \\
\text { measurement } \\
\text { Station. }\end{array}$ & $\begin{array}{l}\text { Run out } \\
\text { length }\end{array}$ & $\begin{array}{c}\text { Slope } \\
\left({ }^{\circ}\right)\end{array}$ & $\begin{array}{l}\text { Water } \\
\text { depth } \\
(\mathrm{m})\end{array}$ & $\begin{array}{c}\text { Deposit } \\
\text { character }\end{array}$ & $\begin{array}{c}\text { Other } \\
\text { comments }\end{array}$ \\
\hline \multicolumn{13}{|c|}{ Powerful long run-out flows due to slope failure triggered by major $(M>6.7)$ earthquake } \\
\hline \multirow{4}{*}{ 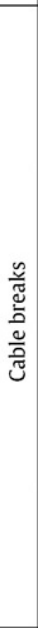 } & $\begin{array}{c}\text { Grand Banks } 1929 \\
\text { Heezen \& Ewing, } \\
\text { 1952; Hughes } \\
\text { Clarke, 1988; Piper } \\
\text { et al. 1988, } 1999\end{array}$ & \begin{tabular}{|c|} 
Major (M 7.2) \\
earthquake \\
triggered slope \\
failures across \\
water depths of \\
$0.5-3.5 \mathrm{~km}$.
\end{tabular} & $\begin{array}{l}19.1 \mathrm{~m} / \mathrm{s} \text { to } 3 \\
\mathrm{~m} / \mathrm{s}: 11 \text { cable } \\
\text { breaks. }\end{array}$ & $\mathrm{x}$ & $\mathrm{x}$ & $\begin{array}{c}160-270 \mathrm{~m} \\
\text { thick in fan } \\
\text { valleys; Up to } \\
300 \mathrm{~km} \text { wide. }\end{array}$ & $\begin{array}{l}\text { Took } 13 \\
\text { hours to } \\
\text { reach last } \\
\text { cable. } \\
\text { Duration } \\
\text { unknown. }\end{array}$ & $>800 \mathrm{~km}$ & $\begin{array}{l}0.3^{\circ} \text { to } \\
0.05^{\circ}\end{array}$ & $\begin{array}{c}\text { Up to } \\
5,500 \mathrm{~m}\end{array}$ & $\begin{array}{c}\text { Clean sand } \\
\text { layer up to } \\
1 \mathrm{~m} \text { thick } \\
\text { across } 600 \mathrm{x} \\
250 \mathrm{~km} .\end{array}$ & $\begin{array}{l}\sim 175 \mathrm{~km}^{3} \\
\text { volume. } \\
\text { Generated } \\
\text { localised } \\
\text { tsunami. }\end{array}$ \\
\hline & $\begin{array}{c}\text { Nice Airport, } 1979 \\
\text { Piper \& Savoye, } \\
\text { 1993; Mulder et al., } \\
1997\end{array}$ & $\begin{array}{l}\text { Small volume } \\
\left(0.008 \mathrm{~km}^{3}\right) \\
\text { slope failure } \\
\text { due to } \\
\text { extension of } \\
\text { airport. }\end{array}$ & $\begin{array}{l}7 \mathrm{~m} / \mathrm{s} \text { to } 1.8 \\
\mathrm{~m} / \mathrm{s} ; 3 \text { cable } \\
\text { breaks }\end{array}$ & $\mathrm{x}$ & $\mathrm{x}$ & $\begin{array}{l}\text { Initially flow } \\
\text { thickness } \\
>30-50 \mathrm{~m} ; \\
\text { thickness on } \\
\text { levee } \\
>120 \mathrm{~m} \text {. }\end{array}$ & $\begin{array}{l}\text { Took } \sim 8.5 \\
\text { hours to } \\
\text { reach last } \\
\text { cable. } \\
\text { Duration } \\
\text { unknown. }\end{array}$ & $\begin{array}{l}>120 \\
\mathrm{~km}\end{array}$ & $\begin{array}{l}14^{\circ} \text { to } \\
0.12^{\circ}\end{array}$ & $\begin{array}{c}0 \text { to }> \\
2,500 \mathrm{~m}\end{array}$ & $\mathrm{x}$ & $\begin{array}{c}\text { Initially } 0.008 \\
\mathrm{~km}^{3} \text { volume; may } \\
\text { have increased } \\
\text { substantially. }\end{array}$ \\
\hline & $\begin{array}{l}\text { Gaoping Canyon, } \\
\text { Taiwan } 2006 \\
\text { Hsu et al., } 2008\end{array}$ & $\begin{array}{l}\text { Major (M 7.0) } \\
\text { Pingtung } \\
\text { earthquakes. }\end{array}$ & $\begin{array}{l}20 \mathrm{~m} / \mathrm{s} \text { to } 3.7 \\
\mathrm{~m} / \mathrm{s}: 14 \text { cable } \\
\text { breaks }\end{array}$ & $\mathrm{x}$ & $\mathrm{x}$ & $\mathrm{x}$ & $\begin{array}{l}\text { Took } 6.5 \\
\text { hours to } \\
\text { reach last } \\
\text { cable. } \\
\text { Duration } \\
\text { unknown. }\end{array}$ & $\begin{array}{c}>380 \\
\mathrm{~km}\end{array}$ & $\begin{array}{l}1^{\circ} \text { to } \\
0.2^{\circ}\end{array}$ & $\begin{array}{c}\text { up to > } \\
4000 \mathrm{~m}\end{array}$ & $\mathrm{x}$ & $\begin{array}{l}\text { two separate } \\
\text { turbidity currents } \\
\text { were triggered; } \\
\text { second one } \\
\text { started in deep } \\
\text { water. }\end{array}$ \\
\hline & $\begin{array}{c}\text { 1954 Orleansville, } \\
\text { Algeria } \\
\text { Heezen and Ewing, } \\
\text { 1955, El Robrini et } \\
\text { al. } 1985 \\
\end{array}$ & $\begin{array}{l}\text { Major (M 6.7) } \\
\text { earthquake. }\end{array}$ & $\begin{array}{c}20.5 \mathrm{~m} / \mathrm{s} \text { and } \\
14.9 \mathrm{~m} / \mathrm{s}\end{array}$ & $\mathrm{x}$ & $\mathrm{x}$ & $\mathrm{x}$ & $\mathrm{x}$ & $\mathrm{x}$ & $\mathrm{x}$ & $\mathrm{x}$ & $\mathrm{x}$ & $\mathrm{x}$ \\
\hline \multicolumn{13}{|c|}{ Powerful long run-out flow generated by canyon-head slope failure due to recent deposition of flood sediment } \\
\hline 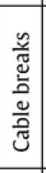 & $\begin{array}{l}\text { Gaoping Canyon, } \\
\text { Taiwan } 2009 \\
\text { (second flow) } \\
\text { Carter et al., } 2012\end{array}$ & $\begin{array}{c}\text { Very large river } \\
\text { flood due to } \\
\text { typhoon: main } \\
\text { flow } 3 \text { days } \\
\text { after flood } \\
\text { peak. } \\
\end{array}$ & $\begin{array}{c}10.3 \text { to } 6.6 \\
\mathrm{~m} / \mathrm{s} \text { from } \\
\text { cable breaks }\end{array}$ & $\mathrm{x}$ & $\mathrm{x}$ & $\mathrm{x}$ & $\begin{array}{l}\text { Took } \sim 10.5 \\
\text { hours to } \\
\text { reach last } \\
\text { cable. }\end{array}$ & $\begin{array}{l}>380 \\
\mathrm{~km}\end{array}$ & $\begin{array}{l}0.2^{\circ} \text { to } \\
0.4^{\circ}\end{array}$ & $\begin{array}{l}\text { up to > } \\
4000 \mathrm{~m}\end{array}$ & $\mathrm{x}$ & $\begin{array}{l}\text { Two flows. First } \\
\text { hyperpycnal; } \\
\text { second failure of } \\
\text { rapidly deposited } \\
\text { sediment. }\end{array}$ \\
\hline \multirow{4}{*}{ 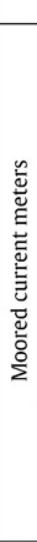 } & \multicolumn{12}{|c|}{ Powerful long run-out flows in river-fed system with unknown triggers } \\
\hline & $\begin{array}{c}\text { Zaire Channel, } \\
2001 . \\
\text { Khripounoff et al., } \\
2004\end{array}$ & $\begin{array}{c}\text { Unknown but } \\
\text { no coeval river } \\
\text { flood }\end{array}$ & $\begin{array}{c}1.2 \mathrm{~m} / \mathrm{s} \text { at } 150 \\
\mathrm{~m} \text { above the } \\
\text { bed: } 1 \mathrm{hr} \text { long } \\
\text { average. }\end{array}$ & $\mathrm{x}$ & $\begin{array}{c}\text { Coarse sand } \\
\text { carried at } \\
40 \mathrm{~m} \text { above } \\
\text { bed }\end{array}$ & $>150 \mathrm{~m}$ & \begin{tabular}{c|}
9 hours \\
(before \\
instruments \\
lost)
\end{tabular} & $\begin{array}{c}>620 \\
\mathrm{~km}\end{array}$ & $0.17^{\circ}$ & $>4000 \mathrm{~m}$ & $\mathrm{x}$ & $\begin{array}{c}\text { Flow in } \\
\text { submarine } \\
\text { channel that is } \\
150 \mathrm{~m} \text { deep and } \\
1-2 \mathrm{~km} \text { wide. }\end{array}$ \\
\hline & \begin{tabular}{|c|} 
Zaire Channel \\
2004. \\
Vangreisheim et al., \\
2009
\end{tabular} & $\begin{array}{c}\text { Unknown. } \\
\text { Zaire River has } \\
\text { low sediment } \\
\text { concentrations } \\
\text { that are unlikely } \\
\text { to plunge }\end{array}$ & $\begin{array}{c}3.5 \mathrm{~m} / \mathrm{s} \\
\text { frontal speed. } \\
\text { Speed }<0.96 \\
\mathrm{~m} / \mathrm{s} \text { at } 60 \mathrm{~m} \\
\text { above bed; } \\
<0.4 \mathrm{~m} / \mathrm{s} \text { at } \\
120 \mathrm{~m} \text { above } \\
\text { bed: } 1 \text { hour } \\
\text { averages. }\end{array}$ & $\mathrm{x}$ & $\begin{array}{l}\text { Clay } 50 \mathrm{~m} \\
\text { above bed } \\
\text { in channel; } \\
\text { clay } 180 \mathrm{~m} \\
\text { above bed } \\
\text { at lobe; silt } \\
\text { \& clay } 30 \mathrm{~m} \\
\text { above bed } \\
\text { at lobe }\end{array}$ & $>120 \mathrm{~m}$ & $<3$ hours & $\begin{array}{c}>1000 \\
\mathrm{~km}\end{array}$ & $\begin{array}{l}0.23^{\circ} \\
\text { to } 0.1^{\circ}\end{array}$ & $>4800 \mathrm{~m}$ & $\mathrm{x}$ & $\begin{array}{c}\text { Flow in } \\
\text { submarine } \\
\text { channel that is } \\
150 \mathrm{~m} \text { deep and } \\
1-2 \mathrm{~km} \text { wide. }\end{array}$ \\
\hline & $\begin{array}{c}\text { Zaire Channel } \\
2009 . \\
\text { Cooper et al., } 2012\end{array}$ & $\begin{array}{l}\text { Unknown. } \\
\text { As above. }\end{array}$ & $\begin{array}{c}\text { Up to } 2.5 \mathrm{~m} / \mathrm{s} \\
11 \text { events. } \\
\text { ADCP data } \\
1-10 \mathrm{~min} \\
\text { averages } \\
\end{array}$ & $\mathrm{x}$ & $\mathrm{x}$ & $\begin{array}{c}\text { 10-120m; } \\
\text { thickness } \\
\text { increases with } \\
\text { flow speed }\end{array}$ & $\begin{array}{c}\text { 1-10 days } \\
\text { (prolonged) } \\
\text { max speeds } \\
\text { only } 1-3 \mathrm{~min} \\
\text { behind front }\end{array}$ & $\begin{array}{c}>125 \\
\mathrm{~km}\end{array}$ & $0.36^{\circ}$ & $>125 \mathrm{~m}$ & $\mathrm{x}$ & $\begin{array}{c}\text { Flow in } \\
\text { submarine } \\
\text { canyon. Very } \\
\text { detailed ADCP } \\
\text { time series }\end{array}$ \\
\hline \multicolumn{13}{|c|}{ Weaker flows generated by slope failures triggered by earthquakes } \\
\hline \multirow{4}{*}{ 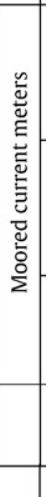 } & $\begin{array}{c}2003 \text { Tokachi-oki } \\
\text { Earthquake, Japan. } \\
\text { Mitsuzawa et al., } \\
\text { 2004; Mikada et al., } \\
2006\end{array}$ & \begin{tabular}{|c|} 
Major \\
earthquake (M 8)
\end{tabular} & \begin{tabular}{|c|}
$<1.4 \mathrm{~m} / \mathrm{s}$ \\
speed of $>0.9$ \\
$\mathrm{~m} / \mathrm{s}$ sustained \\
for $\sim 3$ hours
\end{tabular} & $\mathrm{x}$ & $\mathrm{x}$ & $60 \mathrm{~m}$ & $\begin{array}{c}\text { Duration of } 5 \\
\text { hours at } \\
\text { monitoring } \\
\text { location }\end{array}$ & $\mathrm{x}$ & $\mathrm{x}$ & $>2540 \mathrm{~m}$ & $\begin{array}{c}\text { No deposit } \\
\text { at } \\
\text { monitoring } \\
\text { site; flow } \\
\text { bypassed. }\end{array}$ & $\begin{array}{l}\text { Also measured } \\
\text { temp and } \\
\text { salinity. }\end{array}$ \\
\hline & $\begin{array}{c}\text { Tokachi-oki } \\
\text { earthquake, } \\
\text { Offshore Japan, } \\
\text { 2003. Mikada et al., } \\
2006 \\
\end{array}$ & $\begin{array}{l}\text { Associated with } \\
\text { M 8 earthquake }\end{array}$ & $<1.4 \mathrm{~m} / \mathrm{s}$ & $\mathrm{x}$ & $\mathrm{x}$ & $<60 \mathrm{~m}$ & 5 hours & $\sim 25 \mathrm{~km}$ & $\mathrm{x}$ & $2500 \mathrm{~m}$ & $\mathrm{x}$ & $\mathrm{x}$ \\
\hline & $\begin{array}{c}\text { Offshore Sagami } \\
\text { Bay, Japan, 1997, } \\
\text { 1998, and 2006 } \\
\text { Ikehara et al., 2012 }\end{array}$ & $\begin{array}{c}\text { Associated with } \\
\text { earthquake } \\
\text { swarms }\end{array}$ & $<0.3 \mathrm{~m} / \mathrm{s}$ & $\mathrm{x}$ & $\mathrm{x}$ & $\mathrm{x}$ & $1-3$ hours & $\mathrm{x}$ & $\mathrm{x}$ & $1200 \mathrm{~m}$ & $\mathrm{x}$ & $\mathrm{x}$ \\
\hline & $\begin{array}{l}\text { Cariaco Basin, } 1997 \\
\text { Thunnell et al. } 1999\end{array}$ & \begin{tabular}{|c|} 
Associated with \\
M 6.8 \\
earthquake \\
\end{tabular} & $\mathrm{x}$ & $<0.00005 \%$ & $\mathrm{x}$ & Up to $300 \mathrm{~m}$ & $\mathrm{x}$ & $>90$ & $\mathrm{x}$ & $1450 \mathrm{~m}$ & $\begin{array}{l}\text { deposition } \\
\text { rate } \sim 0.3 \\
\text { mm/day. } \\
\end{array}$ & $\begin{array}{l}\text { Interflow also } \\
\text { observed. }\end{array}$ \\
\hline & \multicolumn{12}{|c|}{ Flow triggered by slope failure in canyon head without earthquake } \\
\hline 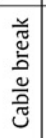 & $\begin{array}{c}\text { Gioia Canyon, } \\
\text { Calabria. Colantoni } \\
\text { et al., } 1992\end{array}$ & $\begin{array}{l}\text { Slope failure } \\
\text { near port }\end{array}$ & $4.5 \mathrm{~m} / \mathrm{s}$ & $\mathrm{x}$ & $\mathrm{x}$ & $>20 \mathrm{~m}$ & $\mathrm{x}$ & $>15 \mathrm{~km}$ & $2.3^{\circ}$ & $>600 \mathrm{~m}$ & $\mathrm{x}$ & $\begin{array}{c}\text { In upper part of } \\
\text { canyon }\end{array}$ \\
\hline
\end{tabular}


Table 1 (continued)

\begin{tabular}{|c|c|c|c|c|c|c|c|c|c|c|c|c|}
\hline \multirow{3}{*}{ 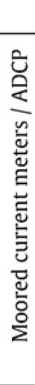 } & \multicolumn{12}{|c|}{ Flow generated directly by plunging of hyperpycnal river floodwater } \\
\hline & $\begin{array}{c}\text { Gaoping Canyon, } \\
\text { Taiwan } 2008 \\
\text { Liu et al., } 2012\end{array}$ & $\begin{array}{c}\text { River flood } \\
\text { associated with } \\
\text { typhoon }\end{array}$ & $\begin{array}{c}\text { Up to } 1.6 \mathrm{~m} / \mathrm{s} \\
\text { measured } \\
56 \mathrm{~m} \text { above } \\
\text { bed }\end{array}$ & $\begin{array}{c}\text { x But } \\
\text { estimated } \\
\text { to be } 0.17 \% \text {; } \\
\text { sufficiently } \\
\text { dilute to } \\
\text { allow ADCP } \\
\text { penetration. }\end{array}$ & $\begin{array}{l}\text { Up to } 40 \% \\
\text { sand in } \\
\text { sediment } \\
\text { trap } 42 \mathrm{~m} \\
\text { above bed }\end{array}$ & Up to 150 & $\begin{array}{c}\text { Waxed and } \\
\text { waned over } \\
14 \text { hours }\end{array}$ & $\begin{array}{l}\mathrm{x} \\
\text { but did } \\
\text { not } \\
\text { break } \\
\text { cables }\end{array}$ & $\sim 1.1^{\circ}$ & $650 \mathrm{~m}$ & $\begin{array}{l}10 \mathrm{~cm} \text { thick } \\
\text { deposit in } \\
\text { trap } 42 \mathrm{~m} \\
\text { above bed- } \\
\text { sand rich. }\end{array}$ & $\begin{array}{c}\text { Did not produce } \\
\text { powerful long- } \\
\text { runout flow as } \\
\text { no cables } \\
\text { broken. }\end{array}$ \\
\hline & $\begin{array}{c}\text { Var 2005-08 } \\
\text { Khripounoff et al., } \\
2009\end{array}$ & River floods & $\begin{array}{l}<0.2 \text { to } 0.7 \\
\mathrm{~m} / \mathrm{s} \text { at } 30 \mathrm{~m} \\
\text { above sea } \\
\text { floor }\end{array}$ & $\begin{array}{l}\text { x but dilute } \\
\text { from } \\
\text { sediment } \\
\text { deposition } \\
\text { rates in } \\
\text { traps. }\end{array}$ & $\mathrm{x}$ & $>30 \mathrm{~m}$ & $\begin{array}{c}\text { Duration of } 8 \\
\text { to } 22 \text { hours }\end{array}$ & $\begin{array}{c}>100 \\
\mathrm{~km}\end{array}$ & $\mathrm{x}$ & $\begin{array}{c}>2350 \\
\mathrm{~m}\end{array}$ & $\begin{array}{c}\text { Accumulated } \\
\text { at }<0.5 \\
\text { mm/day. }\end{array}$ & \\
\hline & \multicolumn{12}{|c|}{ Flow may have been generated by plunging hyperpycnal flood water or by failure of rapidly deposited sediment; } \\
\hline 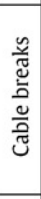 & $\begin{array}{l}\text { Gaoping Canyon, } \\
\text { Taiwan } 2009 \\
\text { (first flow) } \\
\text { Carter et al., } 2012\end{array}$ & \begin{tabular}{c|} 
Very large river \\
flood due to \\
typhoon: first \\
flow occurs \\
during flood but \\
long after peak \\
discharge. \\
\end{tabular} & $\begin{array}{l}16.6 \mathrm{~m} / \mathrm{s} \text { from } \\
\text { initial cable } \\
\text { breaks; but } \\
\text { failed to break } \\
\text { later cables. }\end{array}$ & $\mathrm{x}$ & $\mathrm{x}$ & $\mathrm{x}$ & $>48$ minutes & $\begin{array}{l}>380 \\
\mathrm{~km}\end{array}$ & $1.1^{\circ}$ & $>3000 \mathrm{~m}$ & $\mathrm{x}$ & $\begin{array}{l}\text { Two flows. This is } \\
\text { first flow; second } \\
\text { flow 2-3 days } \\
\text { after flood and } \\
\text { due to failure of } \\
\text { flood deposit in } \\
\text { upper canyon. }\end{array}$ \\
\hline \multicolumn{13}{|c|}{ Short run-out sand-rich flows in canyons fed sand from the shelf } \\
\hline 芯 & $\begin{array}{c}\text { Monterey Canyon } \\
\text { (sub-annual events) } \\
\text { Paull et al., 2010a,b } \\
\text { Paull et al., 2003, } \\
2005 \\
\end{array}$ & $\begin{array}{c}\text { Associated with } \\
\text { periods of large } \\
\text { waves. }\end{array}$ & $\begin{array}{c}\text { Fast -moving } \\
\text { and deformed } \\
1400 \mathrm{~kg} \\
\text { tripods. }\end{array}$ & $\mathrm{x}$ & $\mathrm{x}$ & \begin{tabular}{c|} 
Sand \\
suspended $<5$ \\
m above \\
canyon floor \\
from cores. \\
\end{tabular} & $\mathrm{x}$ & $\begin{array}{c}<\sim 50 \\
\mathrm{~km}\end{array}$ & $1.8^{\circ}$ & $\begin{array}{c}\text { Up to } \\
1450 \mathrm{~m}\end{array}$ & $\begin{array}{c}\text { Formed } \\
\text { crescentic } \\
\text { bedforms in } \\
\text { coarse sand } \\
\text { and pebbles }\end{array}$ & $\begin{array}{c}\text { Cyclic steps or } \\
\text { near bed } \\
\text { liquefied layers } \\
\text { form crescentic } \\
\text { bedforms? }\end{array}$ \\
\hline 气ั̆ & $\begin{array}{c}\text { Monterey Canyon } \\
\text { (sub-annual events) } \\
\text { Xu et al., 2004; Xu, } \\
2011\end{array}$ & $\begin{array}{c}\text { Associated with } \\
\text { periods of large } \\
\text { waves }\end{array}$ & $\begin{array}{c}\text { ADCPs } \\
\text { mounted } 70 \\
\text { m above bed; } \\
<1.9 \mathrm{~m} / \mathrm{s}\end{array}$ & $\begin{array}{c}\mathrm{X} \\
\text { Estimated } \\
0.06-0.04 \% \\
\text { vol from } \\
\text { flow speed }\end{array}$ & $\mathrm{x}$ & $50-80 \mathrm{~m}$ thick & $\begin{array}{l}\text { Duration 5-8 } \\
\text { hours }\end{array}$ & $\begin{array}{c}<\sim 50 \\
\mathrm{~km}\end{array}$ & $1.8^{\circ}$ & $\begin{array}{l}\text { Up to } \\
1450 \mathrm{~m}\end{array}$ & $\mathrm{x}$ & $\begin{array}{l}\text { Max speed near } \\
\text { front of flow- 5- } \\
15 \mathrm{~m} \text { above bed. } \\
\text { All supercritical. }\end{array}$ \\
\hline & $\begin{array}{l}\text { Scripps \& La Jolla } \\
\text { Canyon. } \\
\text { Shepard et al., } \\
\text { 1977; Shepard \& } \\
\text { Dill, 1966; Dill, } \\
\text { 1964; Marshall, } \\
\text { 1978 }\end{array}$ & $\begin{array}{c}\text { Associated with } \\
\text { periods of large } \\
\text { waves; } \\
\text { subannual }\end{array}$ & $\begin{array}{c}<1.9 \mathrm{~m} / \mathrm{s} \text { until } \\
\text { instrument } \\
\text { lost }\end{array}$ & $\mathrm{x}$ & $\mathrm{x}$ & $\mathrm{x}$ & $\mathrm{x}$ & $\mathrm{x}$ & $\begin{array}{c}>5^{\circ} \text { to } \\
1.4^{\circ}\end{array}$ & $<300 \mathrm{~m}$ & Sand rich & $\begin{array}{l}\text { Includes } \sim 0.001 \\
\mathrm{~km}^{3} \text { slump in } \\
\text { canyon head. }\end{array}$ \\
\hline 气ั & $\begin{array}{c}\text { Hueneme and } \\
\text { Mugu Canyons } \\
\text { Xu et al., 2010; Xu, } \\
2010\end{array}$ & 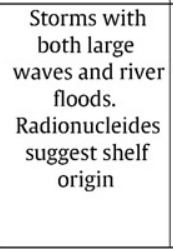 & $\begin{array}{c}\text { ADCPs } \\
\text { mounted } 70 \mathrm{~m} \\
\text { above bed } \\
<2.8 \mathrm{~m} / \mathrm{s} \text { at } \\
4 \mathrm{~m} \text { above bed }\end{array}$ & $\begin{array}{c}\mathrm{x} \\
\text { But layer } \\
\text { average } \\
\text { value of up } \\
\text { to } 0.33 \% \text { vol } \\
\text { calculated } \\
\text { to produce } \\
\text { flow speed }\end{array}$ & $\begin{array}{c}\text { Traps at } 30 \\
\text { and } 60 \mathrm{~m} \\
\text { above bed } \\
\text { have up to } \\
25 \% \text { sand } \\
\text { (Hueneme) } \\
\text { and up to } \\
10 \% \text { sand } \\
\text { (Mugu). }\end{array}$ & $15-25 \mathrm{~m}$ thick & $\begin{array}{c}\text { Duration } 1 \\
\text { hour from } \\
\text { velocity; } \\
\text { although } \\
\text { water turbid } \\
\text { for longer. }\end{array}$ & $>4 \mathrm{~km}$ & $2.1^{\circ}$ & $>188 \mathrm{~m}$ & $\begin{array}{c}\text { Sed in traps } \\
\text { located } 30 \mathrm{~m} \\
\text { above bed } \\
\text { accumulated } \\
\text { at }<3 \\
\mathrm{~mm} / \text { day }\end{array}$ & $\begin{array}{l}\text { Mugu also has } \\
\text { crescent shaped } \\
\text { bedforms } \\
\text { Max speed near } \\
\text { front of flow. All } \\
\text { supercritical. }\end{array}$ \\
\hline \multicolumn{13}{|c|}{ Intermediate power and run-out flows generated on delta fronts } \\
\hline \multirow{4}{*}{ 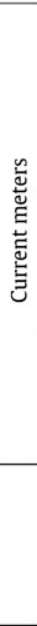 } & $\begin{array}{c}\text { Bute Inlet, Canada } \\
\text { Prior et al., 1987; } \\
\text { Zeng et al., 1991; } \\
\text { Bornhold et al., } \\
\text { 1994; Zeng \& Lowe, } \\
1997 \\
\text { Conway et al., 2012 }\end{array}$ & $\begin{array}{c}\text { Weak flows that } \\
\text { run out short } \\
\text { distances; and } \\
\text { more powerful } \\
\text { longer run out } \\
\text { flows }\end{array}$ & $\begin{array}{c}\text { Weak events } \\
<0.2 \mathrm{~m} / \mathrm{s} \\
\text { Powerful } \\
\text { events }<3.35 \\
\mathrm{~m} / \mathrm{s}\end{array}$ & $\begin{array}{c}\mathrm{X} \\
0.5 \% \text { vol } \\
\text { estimated } \\
\text { from flow } \\
\text { speeds }\end{array}$ & \begin{tabular}{c|} 
Traps \\
contain \\
sand in \\
powerful \\
events; \\
muddy in \\
weak events \\
\end{tabular} & $\begin{array}{c}7-40 \mathrm{~m} \text { thick. } \\
\text { Sand up to } \\
7 \mathrm{~m} \text { above } \\
\text { bed. }\end{array}$ & $\begin{array}{l}2-3 \text { hours for } \\
\text { weaker flow }\end{array}$ & $\begin{array}{c}>26 \mathrm{~km} \text {; } \\
\text { likely } \\
40-50 \\
\text { km }\end{array}$ & $\begin{array}{l}0.71^{\circ} \\
\text { to } \\
0.58^{\circ}\end{array}$ & $>520 \mathrm{~m}$ & \begin{tabular}{|c|} 
Channel \\
site has \\
$47 \mathrm{~cm}$ thick \\
sand \\
deposit.
\end{tabular} & Along a channel. \\
\hline & $\begin{array}{c}\text { Rupert Inlet, } \\
\text { Canada } \\
\text { Hay et al., 1982; } \\
\text { 1987a,b }\end{array}$ & $\begin{array}{l}\text { Mine tailings } \\
\text { releases }\end{array}$ & $\begin{array}{c}0.02 \mathrm{~m} / \mathrm{s} \text { to } \\
0.6 \mathrm{~m} / \mathrm{s} ; \\
\text { measured } 3 \\
\text { and } 13 \text { above } \\
\text { bed. }\end{array}$ & $\begin{array}{c}0.01 \% \text { vol } \\
3 \mathrm{~m} \text { above } \\
\text { bed. Single } \\
\text { data point. }\end{array}$ & $\mathrm{x}$ & $2-5 \mathrm{~m}$ & $\begin{array}{c}<1.5 \text { hours } \\
\text { (main flow in } \\
\text { first few } \\
\text { minutes) }\end{array}$ & $>4 \mathrm{~km}$ & $\begin{array}{l}9.5^{\circ} \text { to } \\
0.47^{\circ}\end{array}$ & $>140 \mathrm{~m}$ & $\mathrm{x}$ & Within channel. \\
\hline & $\begin{array}{c}\text { Itirbilung Fjord. } \\
\text { Syvitski \& Hein, } \\
1991\end{array}$ & $\begin{array}{l}\text { Weak events } \\
\text { due to floods; } \\
\text { strong events } \\
\text { due to delta } \\
\text { slope failures }\end{array}$ & $<0.36 \mathrm{~m} / \mathrm{s}$ & $\mathrm{x}$ & $\mathrm{x}$ & $>2 \mathrm{~m}$ & $\begin{array}{l}\text { Duration 1-5 } \\
\text { hours }\end{array}$ & $>1.5 \mathrm{~km}$ & $>5.7^{\circ}$ & $>50 \mathrm{~m}$ & $\mathrm{x}$ & $\mathrm{x}$ \\
\hline & $\begin{array}{c}\text { Fraser River Delta, } \\
\text { western Canada } \\
\text { Hill, } 2012\end{array}$ & $\begin{array}{c}\text { River floods and } \\
\text { tailings } \\
\text { dispersal. Rapid } \\
\text { deposition } \\
\text { causes delta } \\
\text { slope failures }\end{array}$ & $\mathrm{x}$ & $\mathrm{x}$ & Fine sand & $\mathrm{x}$ & $\mathrm{x}$ & & $\begin{array}{c}5^{\circ} \text { to } \\
1^{\circ}\end{array}$ & $<10 \mathrm{~km}$ & $\mathrm{x}$ & $\begin{array}{l}\text { Data from } \\
\text { repeated } \\
\text { detailed } \\
\text { bathymetric } \\
\text { surveys over } 12 \\
\text { year period. }\end{array}$ \\
\hline 宅 & $\begin{array}{l}\text { Squamish River } \\
\text { delta, British } \\
\text { Colombia. } \\
\text { Hughes Clarke et } \\
\text { al., 2009, 2012, } \\
\text { in press }\end{array}$ & & $\begin{array}{l}1.5 \mathrm{~m} / \mathrm{s} \mathrm{max} \\
0.5 \mathrm{~m} / \mathrm{s} \\
\text { typical for } \\
\text { events }\end{array}$ & $\begin{array}{l}0.001 \% \text { (but } \\
\text { locally } \\
\text { higher) in } \\
\text { surface, } \\
\text { interflow } \\
\text { and sea bed } \\
\text { flow }\end{array}$ & & $10-40 \mathrm{~m}$ & $\begin{array}{c}\text { Velocity } \\
\text { increased for } \\
\text { typically } \sim 1 \\
\text { hour. Sed } \\
\text { plume up to } 7 \\
\text { hours }\end{array}$ & $\begin{array}{c}\text { Often < } \\
2 \mathrm{~km} ; \\
\text { more } \\
\text { rarely > } \\
2 \mathrm{~km} .\end{array}$ & $\begin{array}{c}\text { Avera } \\
\text { ge } 5^{\circ} \\
\text { to } 150 \\
\mathrm{~m} \\
\text { depth }\end{array}$ & $\begin{array}{c}\text { Often< } \\
150 \mathrm{~m} ; \\
\text { more } \\
\text { rarely > } \\
150 \mathrm{~m}\end{array}$ & & $\begin{array}{l}\text { annual bathy } \\
\text { surveys; then } 93 \\
\text { surveys in } 4 \\
\text { years: ADCP at } \\
150 \text { m recorded } \\
30 \text { flows in } 82 \\
\text { days. }\end{array}$ \\
\hline
\end{tabular}




\begin{tabular}{|c|c|c|c|c|c|c|c|c|c|c|c|c|}
\hline & \multicolumn{12}{|c|}{ Flows generated by trawling } \\
\hline 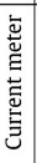 & $\begin{array}{c}\text { La Fonera Canyon, } \\
\text { NW Mediterranean } \\
\text { Palanques et al., } \\
\text { 2006; Puig et al., } \\
2012\end{array}$ & $\begin{array}{l}\text { Most flows due } \\
\text { to trawling; rare } \\
\text { events due to } \\
\text { waves }\end{array}$ & $<0.38 \mathrm{~m} / \mathrm{s}$ & $\begin{array}{c}0.01 \% \text { at } 5 \\
\mathrm{~m} \text { above } \\
\text { bed }\end{array}$ & $\begin{array}{c}1 \% \text { sand; } \\
50 \% \text { silt, } \\
49 \% \text { clay at } \\
22 \mathrm{~m} \text { above } \\
\text { bed }\end{array}$ & $\begin{array}{l}>22 \mathrm{~m} \text { on } \\
\text { occasions }\end{array}$ & $1-6$ hours & $\begin{array}{c}\text { Typically } \\
>3-5 \\
\mathrm{~km} ;<20 \\
\mathrm{~km}\end{array}$ & $\begin{array}{c}2.5^{\circ} \\
\text { along } \\
\text { canyon } \\
\text { axis; } \\
\text { steep } \\
\text { sides }\end{array}$ & $\begin{array}{c}>1200 \\
\mathrm{~m}\end{array}$ & $\begin{array}{l}\text { Rates of } \\
\text { deposition } \\
\text { at } 22 \mathrm{~m} \\
\text { above bed; } \\
0.7 \mathrm{~mm} / \text { day }\end{array}$ & $\begin{array}{l}\text { Some flows that } \\
\text { reached } 1700 \mathrm{~m} \\
\text { water depth } \\
\text { were not due to } \\
\text { trawling. }\end{array}$ \\
\hline
\end{tabular}

to $30 \mathrm{~m}$ ) and typically comprised numerous rotational slumps that were most likely retrogressive (Fig. 2; Piper et al., 1999; Mosher and Piper, 2007). The sediment that initially failed was rapidly deposited proglacial mud and the failure retrogressed until it reached stronger glacial till. This slope failure produced a tsunami wave with run-up heights of $8.5 \mathrm{~m}$ along the coastline of the neighbouring Burin Peninsula, and which travelled across the Atlantic Ocean to be recorded in the Azores and Portugal. The earthquake and tsunami resulted in 28 fatalities (Mosher and Piper, 2007).

The widespread slope failures extended from water depths of $>500$ to $3500 \mathrm{~m}$, and caused 12 cable breaks at the same time as the earthquake (Figs. 1 and 2). A series of 11 cable breaks then occurred that were located in progressively deeper water depths. The first two breaks (nos. 1 and 2; Fig. 1) occurred 59 min after the earthquake. Uncertainties in where the flow originated that caused cable breaks 1 and 2 exclude them from the flow velocity calculations. Two fan-valleys extend down from the initial area of slope failures, and cable break 11 occurred in the Western Valley 183 min after the earthquake. The time at which this same cable broke at a second location in the Eastern Valley (cable break 10; Fig. 1) is not well constrained, as cable break 11 could either have occurred at the same time or after cable break 10. A velocity of $19.1 \mathrm{~m} / \mathrm{s}$ can be calculated using the straight line distance between cable breaks 2 and 11, and a velocity of $\sim 20 \mathrm{~m} / \mathrm{s}$ results from assuming flow along the sinuous thalweg of the Western Valley. Perhaps the most remarkable aspect of this fast velocity is that it occurs on an average sea floor of just $0.3^{\circ}$. This flow may have gained much of its momentum on steeper gradients further upslope, such that its speed is not in equilibrium with local gradient. Other types of particulate density currents (e.g. pyroclastic flows, surges, snow avalanches and debris flows; Levine and Kieffer, 1991; McClung and Shaerer, 2006; Iverson, 1997) can reach this velocity but no other type of flow reaches this velocity on such a low gradient. The next cable breaks recorded flow velocities that declined from $8.2 \mathrm{~m} / \mathrm{s}$ to $3 \mathrm{~m} / \mathrm{s}$ of gradients of $\sim 0.15^{\circ}$ to $\sim 0.05^{\circ}$. The extent of damaged cable indicates that powerful flow was 200 to $300 \mathrm{~km}$ wide on the lower fan (Fig. 1), although flow may not have been continuous across this distance. Heezen and Ewing (1952) and Heezen et al. (1954) reported that cables were buried by sediment over a wider area and that the full width of flow was therefore even wider, and this is consistent with sediment cores (Fig. 3). This flow width greatly exceeds that of most other types of fast moving density current, with the only exception potentially being pyroclastic surges from caldera-forming eruptions (Freundt et al., 2000).

Mapping of the sea floor and sediment coring further constrains the character of the 1929 event. The initial flow travelled down the Western and Eastern fan-valleys that have several hundred metres of relief. Identification from side scan sonar images and submersible dives of trim lines (the maximum height of significant erosion above the sea floor) along the margins of these valleys allowed Hughes Clarke (1988) to estimate that flow thicknesses ranged from $160 \mathrm{~m}$ to $270 \mathrm{~m}$. Side scan images of the floor of the Eastern Valley show that it comprises a field of gravel waves with heights up to $5 \mathrm{~m}$ and wavelengths of 50 to $100 \mathrm{~m}$. These gravel waves extend from waters depths of $\sim 1600 \mathrm{~m}$ down to $\sim 4500 \mathrm{~m}$. These gravel waves may have been reworked during the 1929 event, but the gravel bed itself was deposited originally deposited $\sim 19 \mathrm{ka}$ BP during previous periods of glacial outwash flooding (Piper et al., 2007). Channel thalwegs have been cut through this gravel bed (Hughes Clarke et al., 1990) indicating turbulent erosion during the 1929 event. Mega-scours that include a spectacular $100 \mathrm{~m}$ deep and $1 \mathrm{~km}$ long flute-like feature occur on the floor of the Eastern Valley and may have a Pleistocene origin, but were further eroded by the 1929 flow (Shor et al., 1990; Piper et al., 2007). The gravel waves are progressively overlain in the lower part of the fan-valleys by ribbons and sheets of coarse sand. At the mouth of the fan-valleys in water depths of $\sim 5000 \mathrm{~m}$ there is a transition to macrodunes that are $<5 \mathrm{~m}$ high and up to $300 \mathrm{~m}$ in length and composed of sand. An extensive debris flow deposit has been mapped just below the sea floor on the levee near the end of the Western Valley (Fig. 3; Hughes Clarke, 1988), but whether this deposit was emplaced in 1929 is unclear.

A series of relatively shallow ( $<20 \mathrm{~m}$ deep) channels continue beyond the termination of the main fan valleys (Fig. 3; Hughes Clarke, 1988). The 1929 flow then ran out across the Sohm Abyssal Plain. The deposit from the 1929 event on the Sohm Abyssal Plain is poorly constrained as there are just 16 cores available across an area of $\sim 600 \times 400 \mathrm{~km}$ (Fig. 3). None of these cores recovered a mud cap for the 1929 turbidite, and in many cases the deposit differs significantly from the well known Bouma (1962) sequence (Fig. 3). At least eleven other attempts to core the 1929 deposit have been unsuccessful (Fig. 3). The failure to recover sediment here suggests that these areas are underlain by sand, which is difficult to core. The total volume of the 1929 deposit has been estimated to be $>175 \mathrm{~km}^{3}$ (Piper and Aksu, 1987) but there are large uncertainties on this estimate (Fig. 3). A sediment budget suggests that at least $80 \%$ of sand deposited by the flow was eroded from the Eastern and Western valley floors (Piper and Aksu, 1987; Hughes Clarke et al., 1990; Piper et al., 2007). The sediment that initially failed was primarily pro-glacial mud. Piper and Aksu (1987) noted that the fate of a substantial amount of mud that is unaccounted for in their budget. This missing mud was most likely advected along the continental rise by the western boundary undercurrent or deposited over low hills at the edge of the abyssal plain.

\subsubsection{Offshore Taiwan, Pingtung earthquakes, 2006}

Submarine cable breaks have recorded flow events originating from near the Gaoping Canyon offshore Taiwan (Fig. 5). An event was triggered by the two near-simultaneous Pingtung earthquakes of magnitude 7.0 that occurred in December 2006 (Hsu et al., 2008). Cable breaks 3 and 4 (Fig. 5) record an initial flow (turbidity current 1 ) travelling at $\sim 20 \mathrm{~m} / \mathrm{s}$ on a gradient of $1.0^{\circ}$. The next cable breaks 4 and 5 are separated by $\sim 30 \mathrm{~km}$ and only $4 \mathrm{~min}$. The extreme flow speeds needed for the same flow to have broken cable 5 suggest that a second flow was initiated by other slope failures (Hsu et al., 2008). The distal cable breaks record a flow that travelled at $3.7 \mathrm{~m} / \mathrm{s}$ on a slope of $\sim 0.2^{\circ}$, and then $\sim 5.7 \mathrm{~m} / \mathrm{s}$ on a slope of $0.24^{\circ}$ (Fig. 5). The cable breaks record a flow that ran out for over $300 \mathrm{~km}$ to water depths of $4000 \mathrm{~m}$, and the full run-out distance may have been significantly greater (Fig. 5).

Four cables that cross the canyon remained unbroken, despite cable breaks in adjacent locations, and one cable (no. 14) broke at a much later time (Fig. 5; Hsu et al., 2008). This suggests that flows of up to $5.7 \mathrm{~m} / \mathrm{s}$ do not necessarily break a cable, and that there can be a significant delay between the arrival of the flow front and the cable breaking. This should be borne in mind when using the timing of cable breaks to infer frontal flow speeds. Flow speeds calculated from individual cable 
Table 2

Monitoring data sediment density flows in from lakes and reservoirs.

\begin{tabular}{|c|c|c|c|c|c|c|c|c|c|c|c|c|}
\hline $\begin{array}{l}\text { Location \& } \\
\text { reference's }\end{array}$ & $\begin{array}{l}\text { Triggering } \\
\text { process }\end{array}$ & $\begin{array}{l}\text { Velocity } \\
(\mathrm{m} / \mathrm{s})\end{array}$ & $\begin{array}{l}\text { Sediment } \\
\text { concentration } \\
\quad(\text { vol.\%) }\end{array}$ & $\begin{array}{l}\text { Grain size } \\
\text { suspended }\end{array}$ & $\begin{array}{l}\text { Flow } \\
\text { thickness } \\
(\mathrm{m})\end{array}$ & Duration & $\begin{array}{l}\text { Run out } \\
\text { length }\end{array}$ & $\begin{array}{l}\text { Slope } \\
\left({ }^{\circ}\right)\end{array}$ & $\begin{array}{c}\text { Water } \\
\text { depth (m) }\end{array}$ & $\begin{array}{l}\text { Foude } \\
\text { No }\end{array}$ & $\begin{array}{l}\text { Deposit } \\
\text { character }\end{array}$ & $\begin{array}{l}\text { Other } \\
\text { comments }\end{array}$ \\
\hline \multicolumn{13}{|c|}{ Flows triggered directly by river flood discharge } \\
\hline $\begin{array}{c}\text { Shichikashuku } \\
\text { Reservoir, Japan. } \\
\text { Umeda et al. } 2000 \text { \& } \\
2006\end{array}$ & $\begin{array}{c}\text { River floods with } \\
\text { durations up to } 72 \\
\text { h; silt and clay } \\
\text { concentration at } \\
\text { river mouth is < } \\
0.2 \text { vol.\% sed } \\
\text { concentration }\end{array}$ & $\begin{array}{l}\text { Profile: } \\
<0.08 \mathrm{~m} / \mathrm{s}\end{array}$ & $\begin{array}{l}\text { Turbidity meter } \\
\text { positioned } 2 \mathrm{~m} \text { above } \\
\text { the bed. Sediment } \\
\text { vol. concentration of } \\
<2.8 \times 10^{-3} \% \text {. }\end{array}$ & $<100$ microns & $<3 \mathrm{~m}$ & $2-3$ days & $<7 \mathrm{~km}$ & $\mathrm{x}$ & $<26 \mathrm{~m}$ & $\mathrm{x}$ & $\begin{array}{l}\text { Fine grained } \\
<80 \mu \mathrm{m} . \\
\text { Deposit layer } \\
\text { thickness of } \\
<1.15 \mathrm{~mm} \\
\left(1300 \mathrm{~kg} / \mathrm{m}^{3}\right. \\
\text { assumed for } \\
\text { sed. density })\end{array}$ & $\begin{array}{l}\text { Forms } \\
\text { interflows } \\
\text { along } \\
\text { thermocline. }\end{array}$ \\
\hline $\begin{array}{c}\text { Katsurazawa Reservoir, } \\
\text { Japan. } \\
\text { Chikita \& Okumura, } \\
\text { 1987, 1990; Chikita, } \\
\text { 1989, } 1990 .\end{array}$ & $\begin{array}{l}\text { Meltwater river } \\
\text { floods with } \\
\text { durations of } \\
\text { several days. } \\
\text { Sediment volume } \\
\text { concentrations of } \\
<4 \times 10^{-2} \% \text {. }\end{array}$ & $\begin{array}{c}\text { Maximum } \\
0.32 \mathrm{~m} / \mathrm{s} ; \\
\text { sustained } \\
\text { at }>0.1 \\
\mathrm{~m} / \mathrm{s} \text { for } \\
\text { several } \\
\text { days }\end{array}$ & $\begin{array}{l}\text { Concentration profile } \\
\text { measured with } \\
\text { sediment volume } \\
\text { concentrations of } \\
<7 \times 10^{-2 \%} \text {. }\end{array}$ & $\begin{array}{l}>99 \% \text { silt and } \\
\text { clay }<64 \\
\text { microns }\end{array}$ & $<\sim 6 \mathrm{~m}$ & $\begin{array}{l}\text { Up to } 3 \\
\text { days }\end{array}$ & $<10 \mathrm{~km}$ & $\begin{array}{l}0.5^{\circ} \text { to } \\
0.27^{\circ}\end{array}$ & $8-12 \mathrm{~m}$ & $\begin{array}{l}0.55 \text { to } \\
4.4\end{array}$ & $\begin{array}{l}90 \% \text { silt and } \\
\text { clay }\end{array}$ & $\begin{array}{l}\text { Fully } \\
\text { turbulent. } \\
\text { Forms } \\
\text { interflows. }\end{array}$ \\
\hline $\begin{array}{l}\text { Lillooet Lake, British } \\
\text { Colombia. } \\
\text { Best et al., 2005; Gilbert } \\
\text { et al., 2006. }\end{array}$ & $\begin{array}{l}\text { Meltwater river } \\
\text { floods lasting } \\
\text { several days. }\end{array}$ & $\begin{array}{l}\text { Maximum } \\
0.58 \mathrm{~m} / \mathrm{s} \text {. } \\
\text { ADVP used } \\
\text { for full } \\
\text { flow field } \\
\text { profiles. }\end{array}$ & $\begin{array}{l}\text { Sediment volume } \\
\text { concentrations of } \\
<2.3 \times 10^{-2} \% \text {. }\end{array}$ & $\mathrm{x}$ & 8.5 to $16 \mathrm{~m}$ & $\begin{array}{l}\text { Several } \\
\text { days }\end{array}$ & $>0.5 \mathrm{~km}$ & $>0.95^{\circ}$ & $17-55 \mathrm{~m}$ & $\sim 0.8$ & $\begin{array}{l}<17 \mathrm{~mm} \\
\text { (sandy and } \\
\text { cross-bedded } \\
\text { near delta } \\
\text { foreset; mud } \\
\text { elsewhere) }\end{array}$ & $\begin{array}{l}\text { Pulsing with } \\
\text { period of } 3 \\
\text { to } 16 \text { min; } \\
\text { due to } \\
\text { shifting } \\
\text { plunge line. }\end{array}$ \\
\hline $\begin{array}{l}\text { Kluane Lake, Yukon. } \\
\text { Crookshanks \& Gilbert, } \\
\text { 2008. } 2009 .\end{array}$ & $\begin{array}{l}\text { Meltwater river } \\
\text { floods lasting } \\
\text { several days with } \\
\text { sed. conc. } \\
\text { typically } 0.05 \% \\
\text { vol. Fine }(\sim 10 \\
\mu \mathrm{m}) \\
\text { suspended sed. } \\
\text { with little or no } \\
\text { bedload. }\end{array}$ & $\begin{array}{l}\text { Measured } \\
\text { at } 0.5 \mathrm{~m} \\
\text { above bed. } \\
\text { Maximum } \\
0.6 \mathrm{~m} / \mathrm{s} \text {. }\end{array}$ & $\begin{array}{l}\text { Profiles taken at } 11 \\
\text { locations every day. } \\
\text { Sediment volume } \\
\text { concentrations of } \\
<4.5 \times 10^{-2} \% \text {. }\end{array}$ & $\mathrm{x}$ & $<13 \mathrm{~m}$ & $\mathrm{x}$ & $>4 \mathrm{~km}$ & $1.08^{\circ}$ & $<70 \mathrm{~m}$ & $\begin{array}{l}\text { Up to } 7 \\
1-3 \text { is } \\
\text { typical. }\end{array}$ & $\begin{array}{c}<0.46 \\
\text { mm/day } \\
\text { deposition } \\
\text { rate } \\
<40 \mu \mathrm{m} \\
\text { in size up to } 2 \\
\text { cm thick } \\
\text { when } \\
\text { deposited }\end{array}$ & $\begin{array}{l}\text { Well } \\
\text { developed } \\
\text { upslope } \\
\text { migrating } \\
\text { sediment } \\
\text { waves. }\end{array}$ \\
\hline $\begin{array}{l}\text { Luzzone Reservoir, } \\
\text { Switzerland. } \\
\text { De Cesare et al., } 2001 .\end{array}$ & $\begin{array}{l}\text { River flood with } \\
\text { sed. vol. } \\
\text { concentration of } \\
<3.8 \times 10^{-3} \% \text {. }\end{array}$ & $\begin{array}{c}<0.8 \mathrm{~m} / \mathrm{s} \text {. } \\
\text { Measured } \\
\text { at } 2 \mathrm{~m} \text { and } \\
4 \mathrm{~m} \text { above } \\
\text { bed. }\end{array}$ & $\mathrm{x}$ & $\mathrm{x}$ & $\mathrm{x}$ & $\mathrm{x}$ & $<3 \mathrm{~km}$ & $2.3^{\circ}$ & $\mathrm{x}$ & $\mathrm{x}$ & $\mathrm{x}$ & $\mathrm{x}$ \\
\hline $\begin{array}{l}\text { Lake Lugano, } \\
\text { Switzerland. } \\
\text { De Cesare et al., } 2006 .\end{array}$ & $\begin{array}{c}\text { River flood with } \\
\text { duration of } \sim 1 \\
\text { day; max. sed. vol. } \\
\text { concentration of } \\
\sim 0.3 \% \text {. }\end{array}$ & $0.17 \mathrm{~m} / \mathrm{s}$ & $\begin{array}{l}\text { Measured with CTD } \\
\text { cast. Sediment vol. } \\
\text { concentration of } \\
<2 \times 10^{-2} \%\end{array}$ & $\mathrm{x}$ & $\sim 10 \mathrm{~m}$ & $\mathrm{x}$ & $\mathrm{x}$ & $\mathrm{x}$ & $<160$ & $<1$ & $\mathrm{x}$ & $\begin{array}{c}\text { Forms } \\
\text { interflow. } \\
\text { Reynolds No. } \\
\text { fully } \\
\text { turbulent }\end{array}$ \\
\hline $\begin{array}{c}\text { Lake Geneva, } \\
\text { Switzerland } \\
\text { Lambert \& Giovanoli, } \\
1988\end{array}$ & $\begin{array}{l}\text { River floods with } \\
\text { sediment vol. } \\
\text { concentrations of } \\
\sim 0.1 \text { vol. \% } \\
31 \text { events in } 84 \\
\text { days. }\end{array}$ & $\begin{array}{c}<0.9 \mathrm{~m} / \mathrm{s} \\
\text { often } 0.1 \\
\text { to } 0.5 \mathrm{~m} / \mathrm{s} \text {. } \\
\text { Measured } \\
4 \text { and } 13 \mathrm{~m} \\
\text { above bed. }\end{array}$ & $\mathrm{x}$ & $\mathrm{x}$ & $\mathrm{x}$ & $\begin{array}{l}\text { Typically a } \\
\text { few hours; } \\
\text { up to } 14 \\
\text { hours. }\end{array}$ & $>8 \mathrm{~km}$ & $\mathrm{x}$ & $\begin{array}{c}170 \mathrm{~m} ; 1.6 \\
\text { and } 5.2 \mathrm{~km} \\
\text { offshore }\end{array}$ & $\mathrm{x}$ & $\mathrm{x}$ & $\begin{array}{c}\text { Measured } \\
\text { in channel } \\
\text { that extends } \\
9 \mathrm{~km} ; 40 \% \\
\text { lake water } \\
\text { entrained } \\
\text { into flow. }\end{array}$ \\
\hline $\begin{array}{c}\text { Expectation Lake, British } \\
\text { Colombia. } \\
\text { Weirich, 1984, 1986a,b }\end{array}$ & $\begin{array}{l}\text { Meltwater river } \\
\text { floods lasting } \\
\text { several hours }\end{array}$ & $\begin{array}{l}<1.1 \mathrm{~m} / \mathrm{s} \\
\text { at } 0.5 \mathrm{~m} \\
\text { above bed. }\end{array}$ & $\begin{array}{l}\text { Turbidity meters. } \\
\text { Sediment vol. } \\
\text { concentration of } \\
<1 \times 10^{-2} \% \text {. }\end{array}$ & $\mathrm{x}$ & $<3 \mathrm{~m}$ & $\begin{array}{l}\text { Several } \\
\text { hours }\end{array}$ & $<1 \mathrm{~km}$ & $\begin{array}{l}2^{\circ} \text { to } \\
12^{\circ}\end{array}$ & $<6.7 \mathrm{~m}$ & $>1$ & $\mathrm{x}$ & $\begin{array}{l}27 \text { sensors in } \\
\text { grid within } \\
100 \mathrm{~m} \text { of } \\
\text { shore. } \\
\text { Surface flows } \\
\text { and } \\
\text { interflows }\end{array}$ \\
\hline $\begin{array}{l}\text { Lake Mead } \\
\text { Grover and Howard, } \\
\text { 1938; Bell, 1942; Gould, } \\
1960\end{array}$ & River floods & $\begin{array}{l}<0.25 \mathrm{~m} / \mathrm{s} \\
\text { to } 0.07 \\
\mathrm{~m} / \mathrm{s}\end{array}$ & $\mathrm{x}$ & $\mathrm{x}$ & $\mathrm{x}$ & $\mathrm{x}$ & 10 's km & $0.1^{\circ}$ & $\mathrm{x}$ & $\mathrm{x}$ & $\begin{array}{l}<1 \% \text { sand in } \\
\text { deposits }\end{array}$ & $\mathrm{x}$ \\
\hline $\begin{array}{c}\text { Kamloops Lake, British } \\
\text { Colombia } \\
\text { Pharo \& Carmack, } 1979\end{array}$ & $\begin{array}{l}\text { Meltwater River } \\
\text { floods }\end{array}$ & $\begin{array}{c}0.08 \mathrm{~m} / \mathrm{s} \\
\text { to } 0.28 \\
\mathrm{~m} / \mathrm{s} \\
\text { estimate }\end{array}$ & $\begin{array}{l}\text { Turbidity meters. } \\
\text { sediment vol } \\
\text { concentration of } \\
1 \times 10^{-3} \% \text {. }\end{array}$ & $\mathrm{x}$ & $\sim 10 \mathrm{~m}$ & $\mathrm{x}$ & $>5-10 \mathrm{~km}$ & $4^{\circ}$ & $<120 \mathrm{~m}$ & $\mathrm{x}$ & $\begin{array}{l}\text { Silt \& clay } \\
\text { (beyond } \\
\text { delta front); } \\
\text { mm-scale } \\
\text { laminae }\end{array}$ & $\begin{array}{c}\text { Surface flows } \\
\text { and } \\
\text { interflows. }\end{array}$ \\
\hline $\begin{array}{l}\text { Lake Wallensee, } \\
\text { Switzerland } \\
\text { Lambert \& Hsu, 1979; } \\
\text { Lambert et al., 1976 }\end{array}$ & $\begin{array}{l}\text { River floods } \\
\text { sustained for up } \\
\text { to } 2 \text { days. Lake } \\
\text { floor has channel. }\end{array}$ & $\begin{array}{c}<0.3 \text { to } 0.5 \\
\text { m/s; } \\
\text { sometimes } \\
\text { with pulses }\end{array}$ & $\begin{array}{l}\text { Sediment vol. } \\
\text { concentration of } \\
<1.7 \times 10^{-2} \% \text {. }\end{array}$ & $\mathrm{x}$ & $<7 \mathrm{~m}$ & $\begin{array}{l}\text { Up to } 36 \\
\text { hours }\end{array}$ & $>10 \mathrm{~km}$ & $2.5^{\circ}$ & $90-145 \mathrm{~m}$ & 1.3 & $\begin{array}{l}<1 \mathrm{~cm} \text { thick } \\
\text { graded } \\
\text { laminae } \\
\text { resembling } \\
\text { varves, sandy } \\
\text { bases. }\end{array}$ & $\begin{array}{c}\text { Pulses over } \\
15-20 \text { mins; } \\
\text { sharp inc. in } \\
\text { velocity and } \\
\text { slow } \\
\text { decrease }\end{array}$ \\
\hline \multicolumn{13}{|c|}{ Flows triggered by slope failure } \\
\hline $\begin{array}{c}\text { Lake Geneva, } \\
\text { Switzerland } \\
\text { Lambert \& Giovanoli, } \\
1988\end{array}$ & $\begin{array}{l}\text { Slope failure (?); } \\
\text { occurred } ~ 12 \\
\text { hours after river } \\
\text { flood peak } \\
\text { discharge. }\end{array}$ & $\begin{array}{l}3 \mathrm{~m} / \mathrm{s} \text { from } \\
\text { timing of } \\
\text { when two } \\
\text { moorings } \\
\text { broke. }\end{array}$ & $\mathrm{x}$ & $\mathrm{x}$ & $\mathrm{x}$ & $\mathrm{x}$ & $>8 \mathrm{~km}$ & $\mathrm{x}$ & $\begin{array}{l}170 \mathrm{~m} ; 1.6 \\
\text { and } 5.2 \mathrm{~km} \\
\text { offshore }\end{array}$ & $\mathrm{x}$ & $\mathrm{x}$ & $\begin{array}{c}\text { Measured } \\
\text { in channel } \\
\text { that extends } \\
9 \mathrm{~km} \text { along } \\
\text { lake floor. }\end{array}$ \\
\hline \multicolumn{13}{|c|}{ Flows triggered by mine tailings discharge } \\
\hline $\begin{array}{l}\text { Lake Superior, } \\
\text { ReserveFan. } \\
\text { Normark, 1989; } \\
\text { Normark \& Dickson, } \\
\text { 1976a,b. }\end{array}$ & $\begin{array}{l}\text { Prolonged tailings } \\
\text { discharge with } \\
\text { sediment volume } \\
\text { conc. of } \sim 10^{-2} \% \text {; } \\
\text { into channel }\end{array}$ & $\begin{array}{c}1 \text { current } \\
\text { meter } 3-5 \\
\text { m above } \\
\text { bed. } \\
0.03 \text { to } \\
0.15 \mathrm{~m} / \mathrm{s}\end{array}$ & $\begin{array}{l}\text { Water sampler } \\
\text { 5m above bed; one } \\
\text { measurement. } \\
\text { Sediment vol } \\
\text { concentration of } \\
1.8 \times 10^{-3} \% \text {. }\end{array}$ & $\begin{array}{l}\text { Silt or finer } \\
\text { away from } \\
\text { delta front }\end{array}$ & 3 to $16 \mathrm{~m}$ & $\begin{array}{l}\text { Up to } 2 \\
\text { weeks }\end{array}$ & $>3 \mathrm{~km}$ & $0.83^{\circ}$ & $<230 \mathrm{~m}$ & 1.41 & $\begin{array}{l}\text { silt or finer } \\
\text { on levees }\end{array}$ & $\begin{array}{l}\text { Magnets } \\
\text { used to } \\
\text { document } \\
\text { sed. flux at } \\
\text { different } \\
\text { heights. }\end{array}$ \\
\hline
\end{tabular}



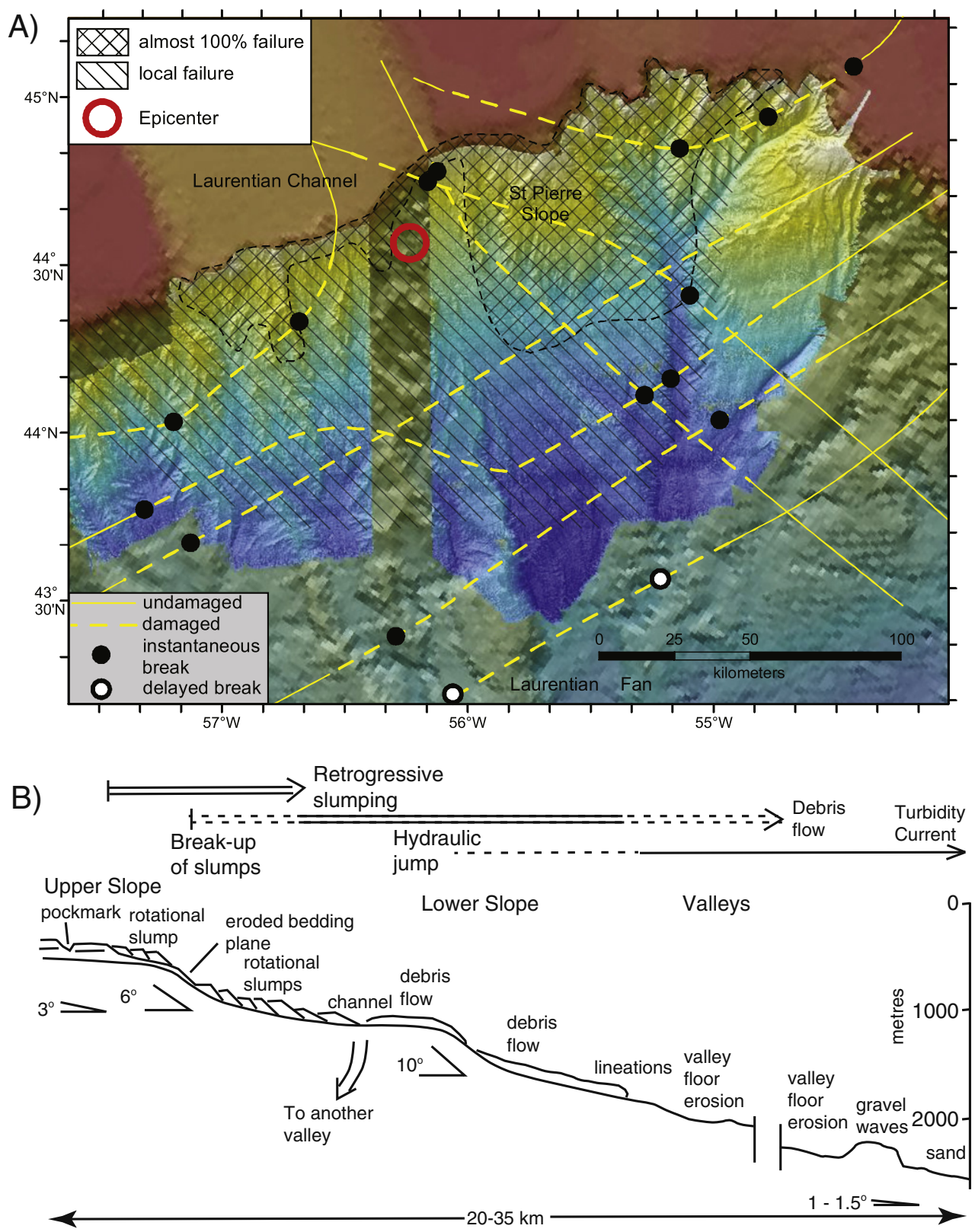

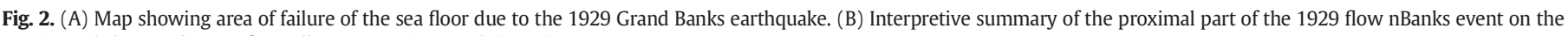
continental slope and upper fan-valleys. From Piper et al. (1999).

breaks during this event show irregular down-flow changes from $\sim 12$ to $\sim 1.5 \mathrm{~m} / \mathrm{s}$ (Gavey, 2012), which may be related to delays in the cable breaking after the flow front arrived.

\subsubsection{Algerian margin, western Mediterranean, 1954, 1980, 2003}

The 1954 Orléansville earthquake $\left(\mathrm{M}_{\mathrm{W}} 6.7\right)$ triggered a flow event on the northern Algeria margin that cut five telephone cables, and the time of three cable breaks was recorded (Heezen and Ewing, 1955; Rothé, 1955; Bourcart and Glangeaud, 1956). Bourcart and Glangeaud (1956) and Heezen and Ewing (1955) inferred that the cables were cut by motion of a landslide triggered by the earthquake, which transformed into a turbidity current that ran out across the Balearic abyssal plain. The calculated flow velocities were $20.5 \mathrm{~m} / \mathrm{s}$ between the first two cable breaks and $14.9 \mathrm{~m} / \mathrm{s}$ between the two more distal cables. The 1980 El-Asnam earthquake $\left(\mathrm{M}_{\mathrm{W}} 7.3\right)$ in Algeria also damaged a cable at a water depth of $1470 \mathrm{~m}$ (El-Robrini et al., 1985). Assuming that the damage to the cable was caused by a turbidity current that started at the shelf break, a flow velocity of $10 \mathrm{~m} / \mathrm{s}$ can be estimated for this event.

A $M_{W} 6.8$ earthquake in 2003 with an epicentre near to the city of Boumerdès caused a series 29 breaks along 5 offshore cables in water depths of up to $2775 \mathrm{~m}$ (Cattaneo et al., 2012). Mapping of the adjacent continental slope showed widespread evidence for recent failures, which generated flows that followed multiple flow paths (Cattaneo et al., 2010, 2012; Nougués et al., 2010). 28 breaks occurred along five cables beyond the continental slope, whose orientation was almost parallel to the base of slope. It is not easy to calculate flow speeds from these numerous breaks, in part due to multiple flows that followed separate paths, and because some adjacent lengths of cable did not break. Flow speeds of between 7.4 and $15.8 \mathrm{~m} / \mathrm{s}$ were calculated by Cattaneo et al. (2012) for the first $70 \mathrm{~km}$ of the flows, assuming that the events were triggered at the shelf break at the time of the earthquake, and followed the shortest possible path. It is surprising that a sixth cable located $80 \mathrm{~km}$ from the shelf edge did not break, suggesting that some cable lengths could withstand very fast flow (Cattaneo et al., 


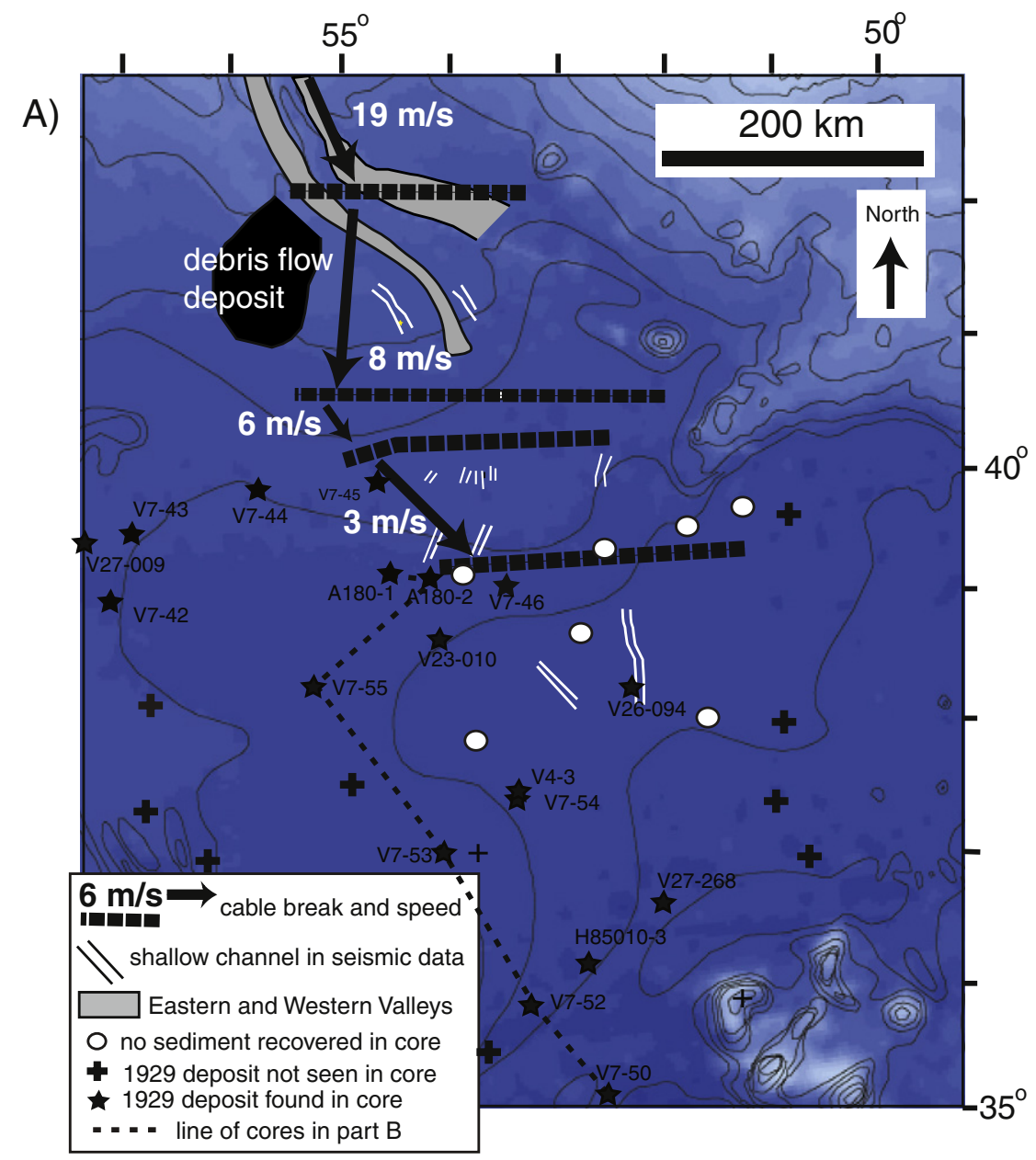

A180-1 A180-2 V7-55 V7-53 V7-52 V7-50

B)
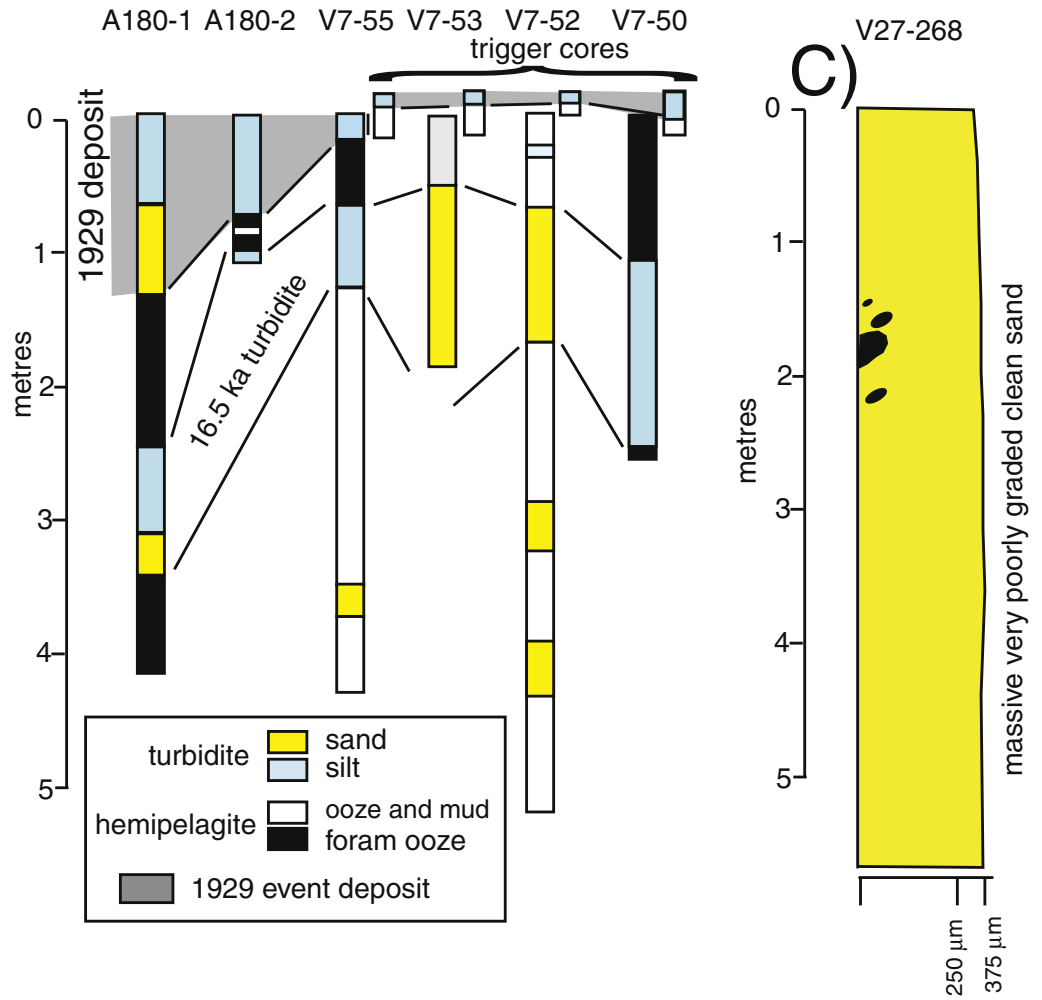


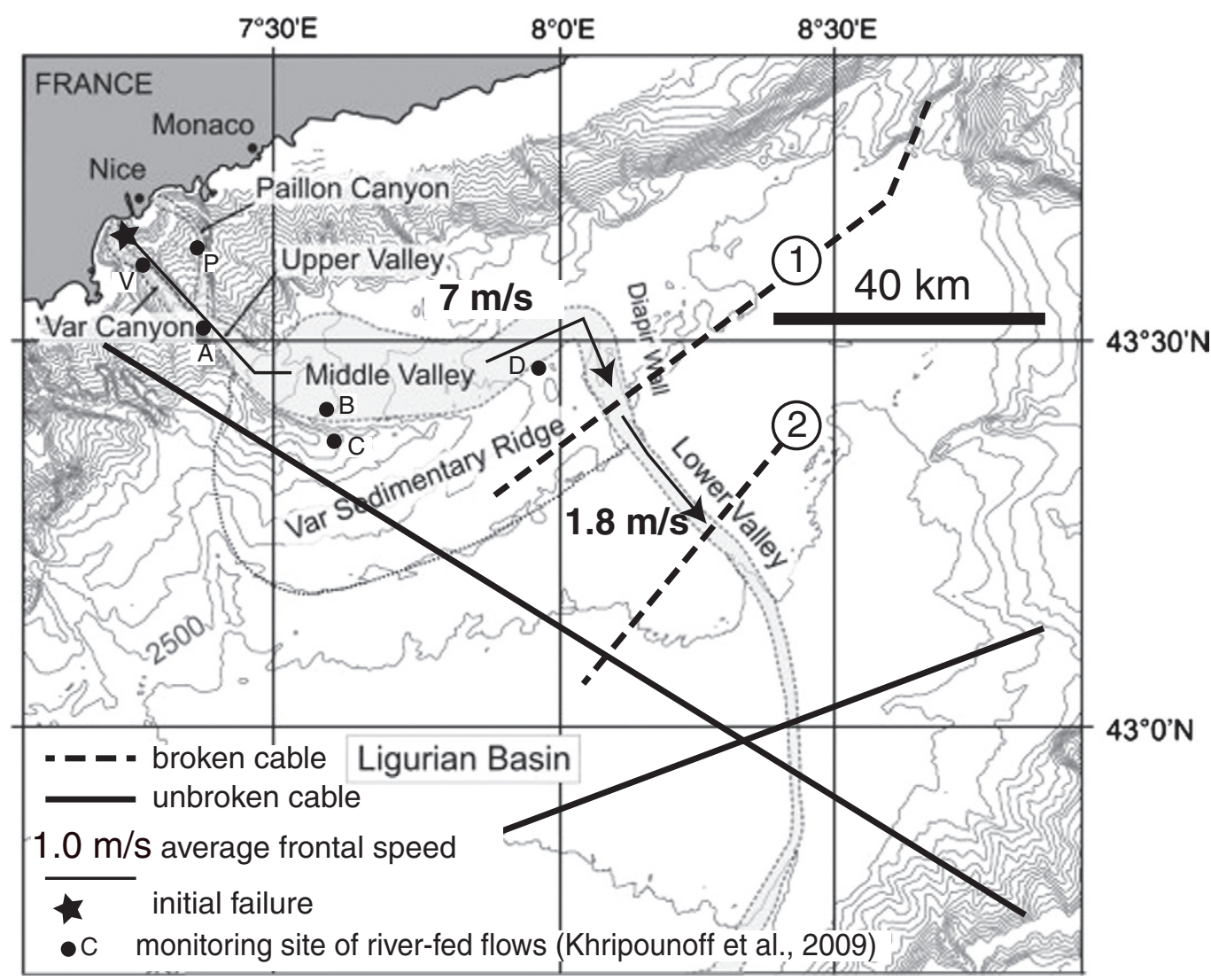

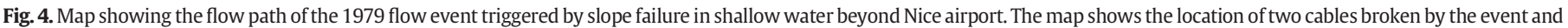
two cables that remained unbroken. After Mulder et al. (1997), Khripounoff et al. (2009, 2009), Mas et al. (2010) and Piper and Savoye (1993).

2012). A single piston core located $70 \mathrm{~km}$ from the coast comprised $\sim 15$ thin silty $(1-10 \mathrm{~cm})$ turbidites emplaced in the last $>8500$ years (Cattaneo et al., 2012). It is not clear whether a thin turbidite at the top of the core was emplaced during the 2003 event, as it cannot be dated with sufficient precision and piston cores can fail to recover sediment immediately below the seafloor. However, the 2003 flow did not leave a thick deposit at this location.

\subsubsection{Tokachi-oki earthquake, offshore Japan, 2003}

The magnitude 8 Tokachi-oki earthquake in September 2003 produced a flow event recorded by acoustic Doppler current profilers (ADCPs) in a cabled observatory offshore Japan, located on the open continental slope. This flow reached a speed of $\sim 1.4 \mathrm{~m} / \mathrm{s}$, was $\sim 60 \mathrm{~m}$ thick, and lasted for $\sim 5$ h (Mikada et al., 2006).

\subsubsection{Offshore Sagami Bay, Japan, 1997, 1998, and 2006}

Flow speeds of up to $0.3 \mathrm{~m} / \mathrm{s}$ were recorded by current meters at the Hatsushima seafloor observatory, together with abrupt changes in water temperature and salinity, associated with the Izu-toho-oki earthquake swarms (Ikehara et al., 2012). The flows lasted for 1-3 h. Sampling of the sea floor suggests that these flows did not deposit sand near the observatory (Ikehara et al., 2012).

\subsubsection{Cariaco Basin, 1997}

Measurements of light scattering and increased flux in sediment traps defined an event in the Cariaco Basin, most likely triggered by a magnitude 6.8 earthquake whose rupture was $\sim 90 \mathrm{~km}$ distant (Thunnell et al., 1999). A zone of increased turbidity was observed that was up to $300 \mathrm{~m}$ thick, albeit with maximum sediment concentrations of only 0.00005 vol.\%. An even more dilute interflow occurred at a water depth of $\sim 300 \mathrm{~m}$ (Thunnell et al., 1999). Settling fluxes into the trap on the bed reached $4.3 \mathrm{~g} / \mathrm{m} /$ day, or $0.3 \mathrm{~mm} /$ day assuming a density of $1300 \mathrm{~kg} / \mathrm{m}^{3}$ for the deposited material.

\subsection{Flows triggered by canyon-head slope-failures unrelated to earthquakes}

The following events were triggered by relatively small volume slope failures in canyon heads, which were not related to earthquakes or river floods. The Var Canyon event in 1979 was triggered by rapid addition of sediment to the canyon head by man, whilst the source for the Gioia Canyon flow in 1977 is poorly known, but did not coincide with earthquake or flood (Colantoni et al., 1992).

\subsubsection{Var Canyon, Mediterranean, 1979 "Nice Airport" event}

A long run-out event in 1979 was triggered by a failure of $0.008 \mathrm{~km}^{3}$ of sediment associated with recent construction of an extension to Nice Airport (Fig. 4; Gennesseaux et al., 1980; Piper and Savoye, 1993; Mulder et al., 1997; Dan et al., 2007). The event generated a small tsuna$\mathrm{mi}$ and caused several fatalities. The initial slope failure evolved into a flow that (at least partly) eroded a 150 to $300 \mathrm{~m}$ wide and 25 to $40 \mathrm{~m}$ deep chute. The flow subsequently entered the Var submarine canyon.

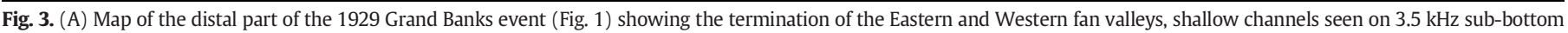

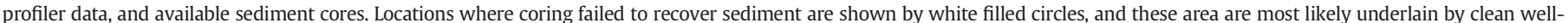

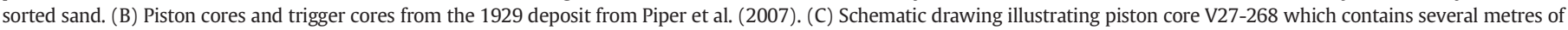
massive ungraded or poorly graded clean sand.

Panel A is after Hughes Clarke (1988). 

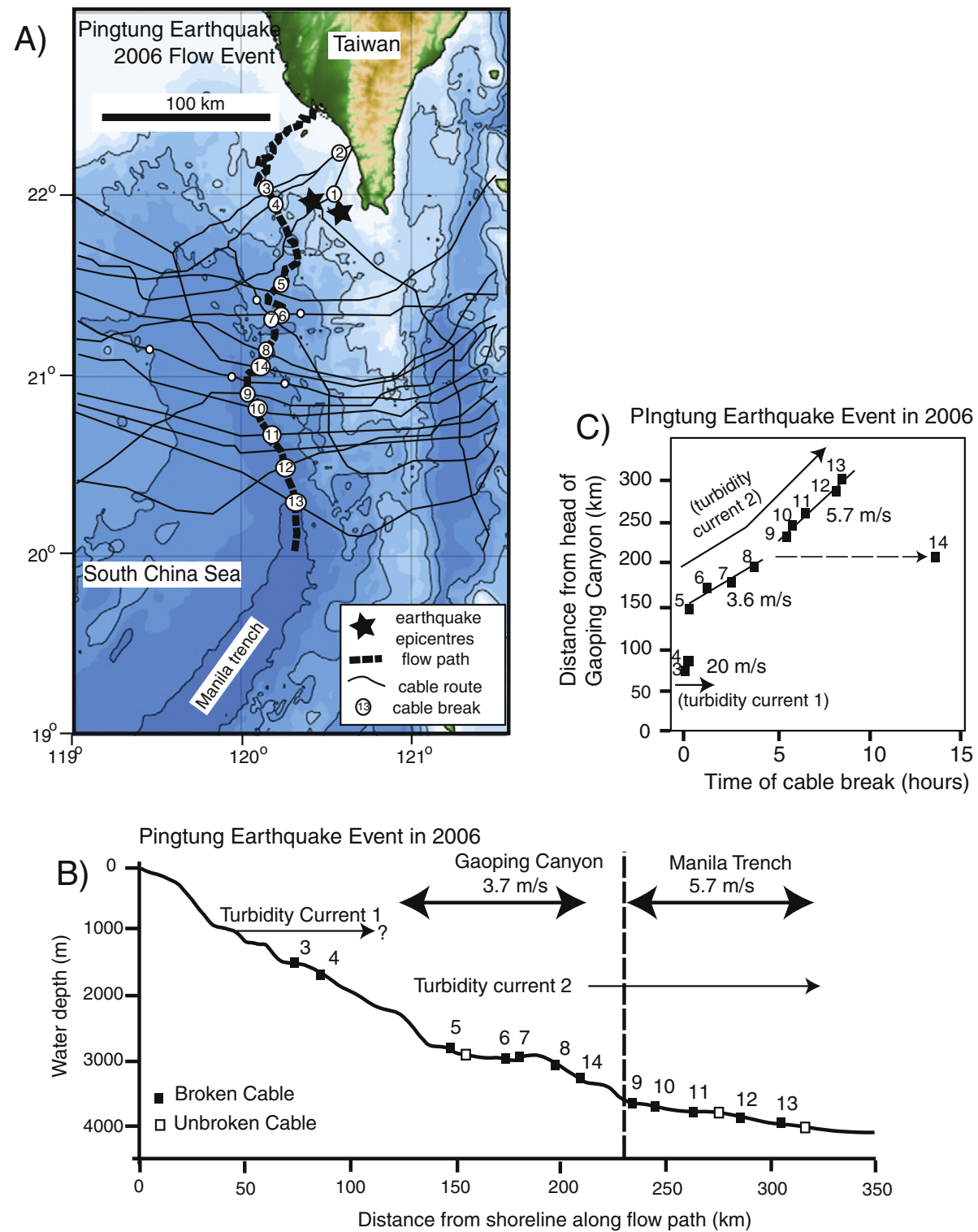

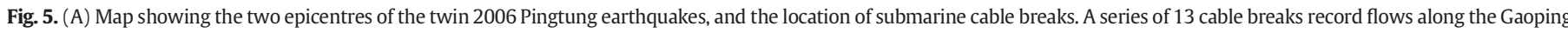

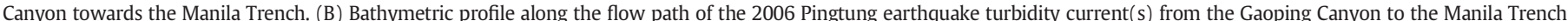

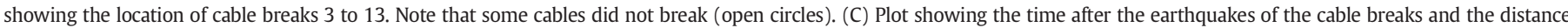

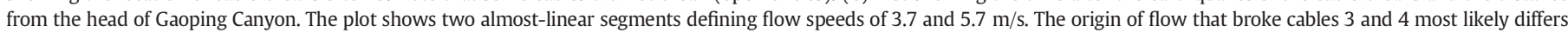
from the origin of the flow that broke cable 5, as a short time period separates cable breaks 4 and 5. Figure is after Hsu et al. (2008).

The initial $10 \mathrm{~km}$ of the canyon is relatively steep $\left(4^{\circ}\right.$ to $\left.14^{\circ}\right)$ and erosional. The canyon is floored by gravel bedforms that extend to water depths of $1650 \mathrm{~m}$, and there is an erosional trim-line located 30 to $50 \mathrm{~m}$ above the canyon floor. Pieces of metal (parts of a bulldozer) from Nice Airport were found $30 \mathrm{~m}$ above the canyon floor. The fan valley located further down-slope has a 50 to $350 \mathrm{~m}$ high southern levee, a floor of patchy sand and gravel, and a low $(<50 \mathrm{~m})$ northern levee. The levees are composed of thin sand beds. A surface sand bed apparently resulting from the 1979 event is found on the northern levee, but this deposit is absent on the high southern levee, but is present where levee elevation is less than $120 \mathrm{~m}$ (Piper and Savoye, 1993).

The lower fan-valley terminates in water depths of $\sim 2500 \mathrm{~m}$ in the Ligurian Abyssal Plain (Fig. 4). Two cables broke due to the 1979 event, some 100 and $120 \mathrm{~km}$ from the initial slope failure at the mouth of the canyon (Piper and Savoye, 1993). The timing of these cable breaks indicates an average frontal speed of $7 \mathrm{~m} / \mathrm{s}$ over the first $100 \mathrm{~km}$ of the flow path where sea floor gradients decrease from $\sim 8^{\circ}$ to $\sim 0.14^{\circ}$, and average $\sim 1.4^{\circ}$. Flow velocity averaged $\sim 1.8 \mathrm{~m} / \mathrm{s}$ over the following $\sim 30 \mathrm{~km}$ on sea floor gradients of $0.14^{\circ}$ to $0.11^{\circ}$ (Fig. 4 ; Piper and Savoye, 1993). Damage to cable 1 extended for $\sim 80 \mathrm{~km}$, whilst the damaged length of cable 2 was $\sim 30 \mathrm{~km}$ (Piper and Savoye, 1993) placing some constraints on flow width. Two cables located $\sim 40 \mathrm{~km}$ further downslope remained unbroken (Piper and Savoye, 1993) either because the flow did not reach them, or that the final stages of the flow were too slow to break them. The first cable broke several kilometres east of the axis of the canyon, suggesting that flow front overtopped the low levee crest in this area (Mulder et al., 1997).

The total volume of sand deposited by the 1979 flow is poorly constrained by the available seismic, sidescan and core data, and it is difficult to assess the relative importance of sand entrainment along the flow path, with published estimates differing by an order of magnitude (Piper and Savoye, 1993; Mulder et al., 1997). Nevertheless, only about $15 \%$ of the initial failed sediment volume of $0.008 \mathrm{~km}^{3}$ appears to have been sand (i.e. $0.0012 \mathrm{~km}^{3}$; Dan et al., 2007) and even a 
conservative estimate of deposited sand volume is two orders of magnitude greater than this.

\subsubsection{Gioia Canyon, offshore Calabria, Italy, 1977}

Colantoni et al. (1992) described a flow event that occurred on 12 July 1977 in Gioia Canyon offshore Calabria, Italy. This flow was initiated by a slope failure at the head of the canyon next to the port. The flow broke a cable at $600 \mathrm{~m}$ water depth some $15 \mathrm{~km}$ downslope, allowing a flow speed of $4.5 \mathrm{~m} / \mathrm{s}$ to be estimated on a mean slope of $\sim 2.3^{\circ}$. These flow speeds are consistent with transport of pebbles seen on the canyon floor. Significant canyon-flank erosion was seen to heights of $\sim 20 \mathrm{~m}$ above the canyon floor.

\subsection{Flows associated mainly with strong wave action}

The following section outlines flows that are restricted to canyons that are associated mainly with large wave heights on the sea surface. Wave action can cause rapid deposition of sediment in the canyon head, may destabilize slopes by cyclic loading, and in coastal settings breaking waves can result in seaward flows as rip currents. This section initially describes flows in canyons that are fed mainly with sand from the shelf (Monterey, Mugu, Hueneme and Scripps Canyons). This is followed by flows in canyons fed by cross-shelf gravity currents containing greater amounts of mud (Eel Canyon). Resuspension of fine-grained river flood sediment by wave action plays an important role in the cross-shelf gravity currents that supply this type of system. The next section describes particularly dilute and slow moving canyon-confined flows associated with large wave heights (Nazare Canyon). The final section describes flows on the open continental slope associated with Hurricane Iwa, offshore Hawaii.

\subsubsection{Monterey Canyon, offshore California}

Monterey Canyon is one of the largest submarine canyons on the Pacific Coast of North America, and begins within 100 m of the shoreline. A series of studies have shown that sediment transport events occur with a sub-annual frequency in the mid-to-upper part of Monterey Canyon in water depths down to 1850 m (Figs. 6 to 9; Xu et al., 2004; Paull et al., 2010a; Xu et al., 2013).

One study involved intentionally burying three acoustic beacons encased in $45 \mathrm{~kg}$ concrete blocks ('monuments') at a water depth of $\sim 300 \mathrm{~m}$ water depth and periodically re-measuring their position (Paull et al., 2010a). During a 26-month period in 2007 and 2008 the monuments moved 1.0 to $1.7 \mathrm{~km}$ down canyon in at least 6 discrete events. There were several informative features in how the three initially adjacent monuments moved down the canyon. The monument that was initially at the back of the grouping travelled furthest down canyon (Fig. 7). Sometimes a monument remained stationary, whilst an initially closely adjacent monument was carried significant distances down canyon (Fig. 7). The beacons in the concrete monuments continued to function, suggesting that the monuments were not vigorously tumbled as strong impacts would most likely have stopped the beacons working.

Other events in both 2001 and 2007-08 moved instrument frames deployed on the canyon floor up to $550 \mathrm{~m}$ down-canyon from their deployment sites (Paull et al., 2003, 2010a). One frame that weighed $1360 \mathrm{~kg}$ moved $170 \mathrm{~m}$ down-canyon (Paull et al., 2010a). The frames and monuments deployed were found buried to depths of $\sim 60$ to $\sim 170 \mathrm{~cm}$ in sandy sediment.

Whilst these events were sufficiently powerful to move and deform components of heavy metal frames, these events do not appear to have long run-out distances, as they are not recorded by monitoring equipment placed at $3450 \mathrm{~m}$ water depth (a further $\sim 90 \mathrm{~km}$ downslope; Fig. 6a). The last sand-carrying event to exit the canyon and travel through the Monterey Fan Channel is believed to have occurred $\sim 100$ years ago (Paull et al., 2010b). Thus, sand appears to be accumulating within the upper-to-mid canyon during sub-annual events.
The sub-annual events in the upper canyon are commonly associated with periods of large waves (Paull et al., 2003; Xu et al., 2004; Paull et al., 2010a). Flood related sediment discharges from the Salinas and Pajaro Rivers periodically occur which may generate hyperpycnal flows (Johnson et al., 2001). However, flooding events with sufficient magnitude to produce a hyperpycnal flow have not occurred during the time when there has been monitoring equipment within Monterey Canyon. In one instance, an event in the upper canyon was coincident with strong ground shaking associated with the installation of a new bridge foundation near the canyon head (Paull et al., 2010a), and an additional event may have been triggered by the 1989 Loma Prieta ( $M_{W}$ 7.1) earthquake (Garfield et al., 1994). No empirical observations exist for what triggers the less frequent and larger volume and longer run-out flows that exit the canyon every $\sim 100$ years.

These sub-annual events are associated with the movement of crescent shaped bedforms on the canyon floor that are up to $2.5 \mathrm{~m}$ in amplitude, and have wavelengths of 20 to $80 \mathrm{~m}$ (Fig. 6; Smith et al., 2005, 2007; Xu et al., 2008; Paull et al., 2010a, 2011). These features are characteristically concave down-canyon and are asymmetric with steep $\left(15^{\circ}\right)$ faces in a down-canyon direction, and almost flat gradients on their up-canyon limb. A master headscarp is sometimes apparent that forms a local knickpoint below which an individual train of bedforms becomes progressively less distinct (Paull et al., 2011). Repeat mapping surveys show that these features are active as the position of these scarps change significantly between surveys conducted only months apart (Smith et al., 2005, 2007; Xu et al., 2008; Paull et al., 2010a). Near the head of the canyon the crescent shaped bedforms are composed of coarse and clean sand, often with chaotic mud clasts. However, the bedforms can be traced out to water depths of at least $2200 \mathrm{~m}$, and with increasing water depths contain increasing amounts of coarse material including angular boulders (Paull et al., 2011). However, coarse sand does not extend for more than 2-6 $\mathrm{m}$ up the side of the canyon (Paull et al., 2005, 2010a). Thin sand layers occur up to $\sim 10 \mathrm{~m}$ above the canyon floor, but there are almost no sand or silt horizons more than $25 \mathrm{~m}$ above the canyon floor (Paull et al., 2005). This suggests that the crescent shaped bedforms are associated with flow events that are $<\sim 4$ to $10 \mathrm{~m}$ thick. The bedforms are found from water depths of $11 \mathrm{~m}$ at the very head of the canyon to water depths of at least $2100 \mathrm{~m}$. Some trains of crescent shaped bedforms lead to re-entrants in the sides of the canyon (Paull et al., 2011). Areas of symmetric bedforms that with the opposite (concave up canyon) sense of curvature occur in the mid canyon, and may represent compressional ridges where sediment is accumulating (Paull et al., 2011).

Three hypotheses have been put forward previously to explain the origin of these crescent shaped features (Smith et al., 2005, 2007; Xu et al., 2008; Paull et al., 2010a, b; Cartigny et al., 2010; Fig. 8), to which we add a fourth model. Initially it was presumed that they were sand waves which migrated with the tidal currents, but this is inconsistent with the coarse and poorly sorted sediments of which they are composed (Smith et al., 2005, 2007; Xu et al., 2008). The second hypothesis is that they form by liquefaction and episodic slumping of the coarse sediment-fill along the thalweg of the canyon, and represent slump scars formed as the dense liquefied material finally compacted (Paull et al., 2010a). The third hypothesis is that the features result from repeated erosion and deposition due to series of hydraulic jumps within initially supercritical flows (cyclic steps that migrate up-slope; Sun and Parker, 2005; Taki and Parker, 2005; Cartigny et al., 2010). A fourth hypothesis can be proposed that combines elements of the second two hypotheses; that the bedforms are formed by cyclic steps in thin and dense flows of sand, and that the dense flows of sand are generated by breaching (Fig. 8; Paull et al., 2011). Experiments have shown how up-slope migrating cyclic steps can be produced by flows with high sediment volume concentrations of up to 40 vol.\% (Winterwerp et al., 1992). Dredging has shown how sustained dense flows of sand can be generated by breaching, whereby flow starts at a local steeping at the base of slope, and then 'eats' its way back upslope (Mastbergen and 

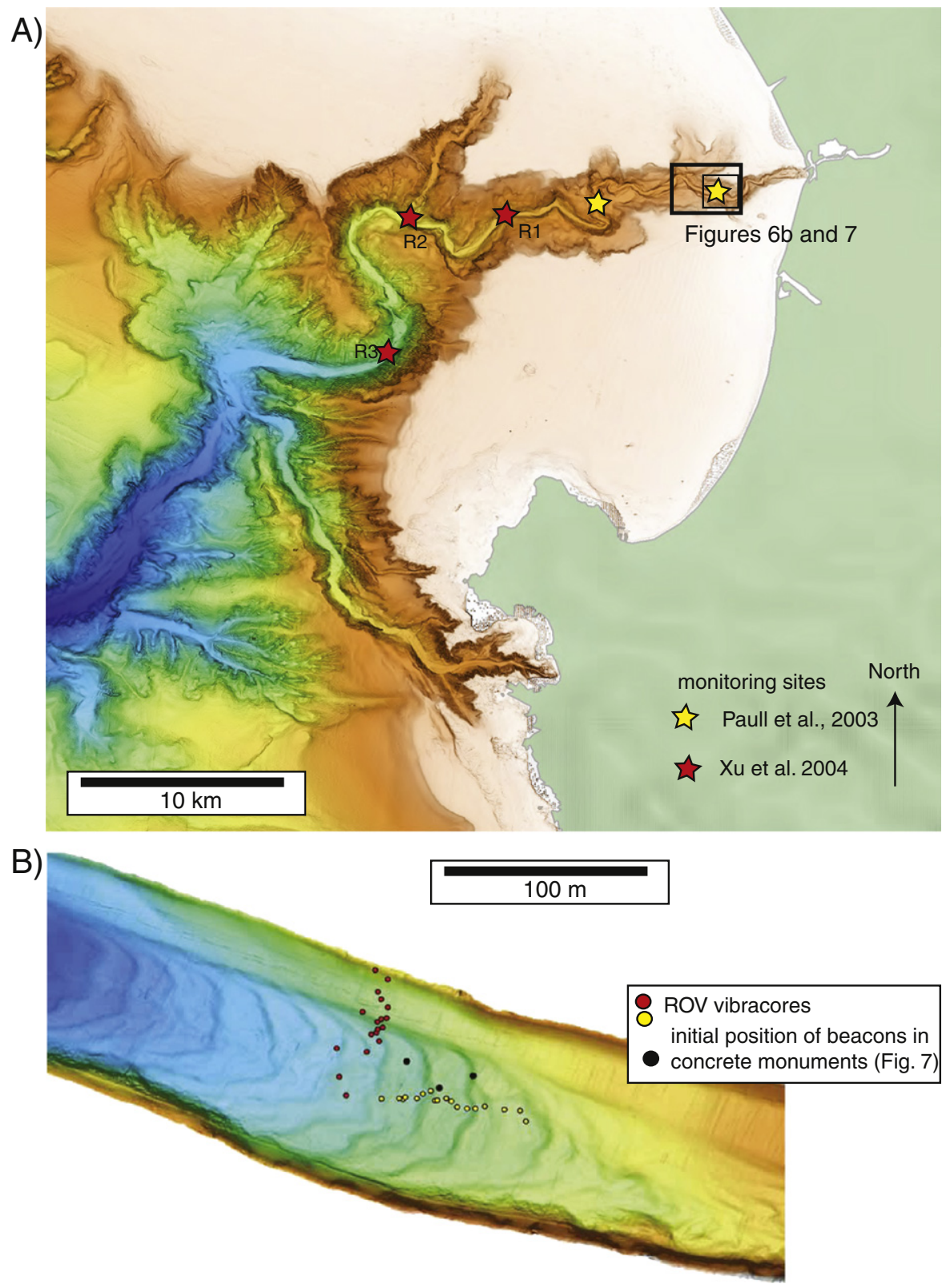

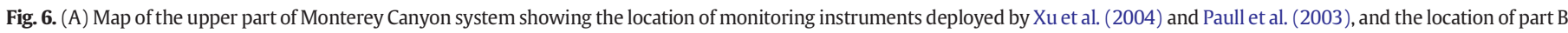

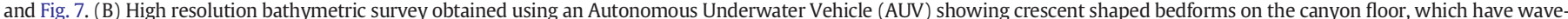

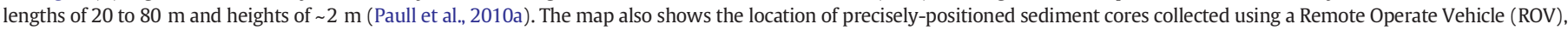
and the initial positions of three $45 \mathrm{~kg}$ concrete monuments with beacons, whose subsequent movements is shown in Fig. 7. Fig. after Paull et al., 2010a.

van den Berg, 2003). Such a breaching process can form a series of hydraulic jumps (Mastbergen and van den Berg, 2003; their figure 3). This hypothesis is consistent with field evidence that sand flows were thin and dense, and that flows appear to originate within the canyon; it is otherwise difficult to explain why bedforms are already well developed in water depths of just $11 \mathrm{~m}$ (Paull et al., 2010a). Dense (weakly turbulent or laminar) flow may explain why monuments were not tumbled, and why some frames remained upright. The dense breaching flow may retrogress back upslope before stopping to leave a distinct head scarp. Monuments outside the head scarp may remain stationary, whilst adjacent monuments are carried downslope in the flow. Such flows could sometimes originate in scars along the sides of the canyon, and produce areas of local sediment accumulation and compression comprising crescent shaped bedforms that are concave down-canyon. It is as yet unclear how and where breaching could be initiated, as the canyon axis gradient is on average only $1.8^{\circ}$ (Paull et al., 2011), and breaching appears to need much steeper slopes to be initiated (Mastbergen and van den Berg, 2003). Breaching might originate on the steeper $\left(15^{\circ}\right)$ faces of crescent shaped bedforms, or by sand transport from the shelf that over-steepens local areas near the canyon head, with such transport associated with periods of large wave heights.

Xu et al. (2004) and Xu (2010, 2011) measured vertical velocity profiles through relatively dilute flows that occurred in the Monterey Canyon in 2002 and 2003. Downward pointing acoustic Doppler current profilers (ADCPs) at three sites recorded the velocity profiles (Fig. 9). The ADCP velocity measurements are 5-minute averages made every hour, and maximum flow velocities may therefore not have been measured. The maximum recorded velocities in the most powerful event were $\sim 1.6$ to $1.9 \mathrm{~m} / \mathrm{s}$, and these velocities occurred at heights of 5 to 

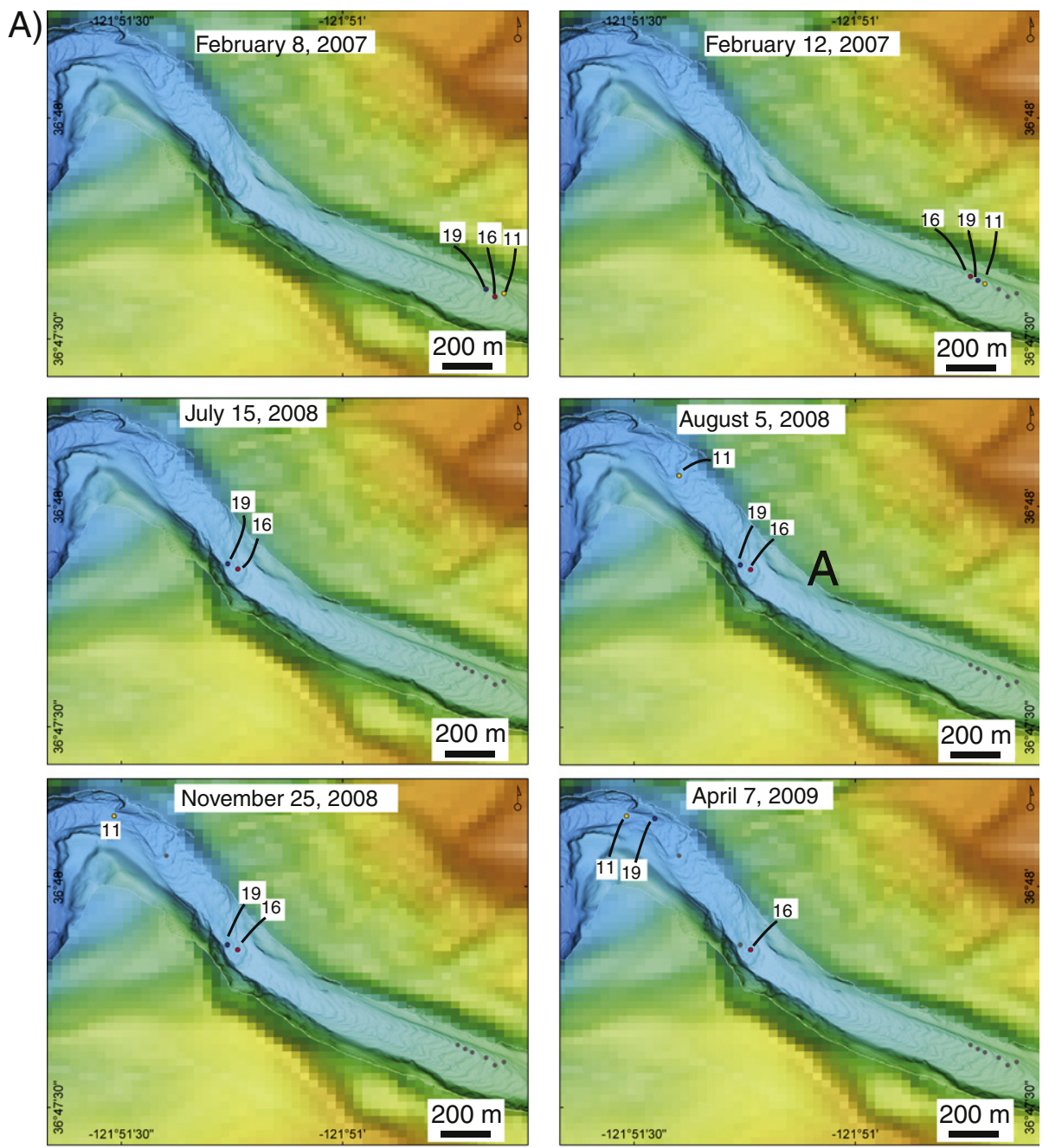

B)

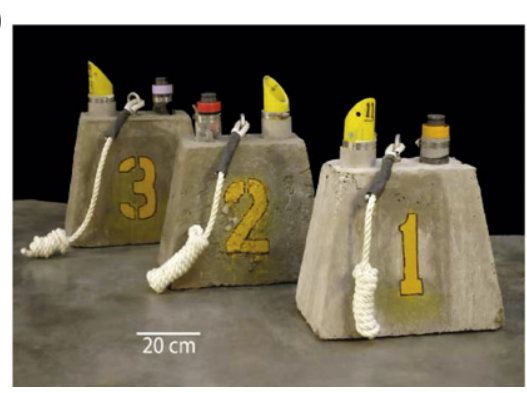

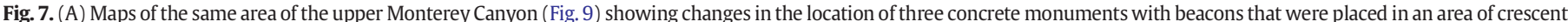

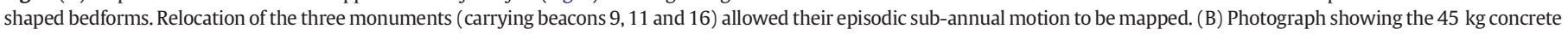
monuments containing acoustic beacons (yellow shroud) that were initially buried within the floor of Monterey Canyon. From Paull et al. (2010a).

$12 \mathrm{~m}$ above the sea floor (Fig. 9). The flows lasted for 5 to $8 \mathrm{~h}$, and were 50 to $\sim 80 \mathrm{~m}$ thick. The sea floor gradient was $\sim 1.8^{\circ}$ in the area of measurements, and flow was strongly confined by the canyon walls. It took several days for fine sediment to settle out to background values in the measurement locations. Subsequently, a later event moved a $1000 \mathrm{~kg}$ anchor at $\sim 0.5 \mathrm{~m} / \mathrm{s}$ for at least $600 \mathrm{~m}$ before the cable parted at a height of $\sim 70 \mathrm{~m}$ above the sea floor.

Sediment concentrations of 0.08 to 0.15 vol.\% were measured at a point $\sim 10 \mathrm{~m}$ above the bed in 2002 , although saturation of the signal means that concentrations were sometimes higher for the initial few hours of flow. Penetration of the ADCP through tens of metres of the flow shows that sediment concentrations were $\ll 5$ vol.\% (Hurther et al., 2011). Xu et al., 2010 calculated that a depth averaged sediment volume concentration of 0.04 to $0.06 \%$ was needed to obtain the observed flow speeds and thicknesses, using a Chezy-type equation (Bowen et al., 1984) that is discussed in Section 7.2.2.2. The velocity profiles have a similar shape to those of supercritical laboratory flows (Sequeiros et al., 2010), when scaled by flow thickness and depth averaged speed. This is consistent with calculations suggesting the flows were supercritical (Xu, 2010, 2011; Xu et al., 2013). These dilute flows were observed to reach their maximum velocity close to the flow front within $<10$ min of its arrival.

Whether the type of event analysed by Xu et al. (2004) is the same as the events that formed the crescent shaped bedforms and moved the 


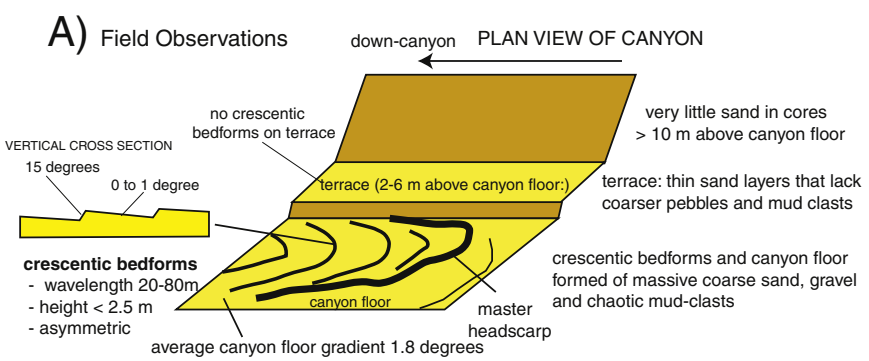

B) Hypothesis 1 - Crescentic bedforms are late-stage slump scars farcturing may occur as a dense

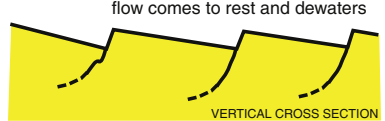

C) Hypothesis 2 - Crescentic bedforms formed by cyclic steps generated by a thin and dense flow that retrogresses up-slope (via breaching)

mixing with seawater may create overlying dilute turbdity current

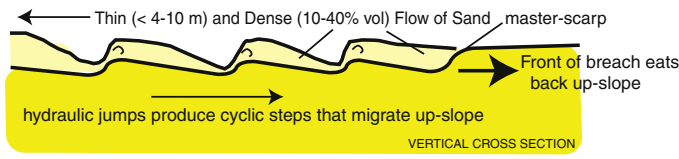

Fig. 8. (A) Schematic summary of the field observations in the upper Monterey Canyon made by Paull et al. (2010a,b). Plan view shows crescent shaped bedforms that occur on the canyon floor, but are absent on terraces 2-6 $\mathrm{m}$ above the canyon floor. The average gradient of the canyon floor is $\sim 1.8^{\circ}$. (B) Hypothesis that crescent shaped bedforms are produced by slumps or dense liquefied sand flows that are only a few metres thick, which come to an abrupt halt as excess pore pressure dissipates (from Paull et al., 2010a). The crescent shaped bedforms are formed by listric faults in the consolidating sand. (C) Hypothesis that crescent shaped bedforms originate from up-slope migration of cyclic steps generated by hydraulic jumps in a thin and dense flow of sand. The thin and dense flows of sand on the canyon floor are only weakly turbulent, and may be overlain by a thicker, fully turbulent and dilute turbidity current. Partly after Fig. 5 of Cartigny et al. (2010) and Fig. 3 of Van den Berg and Mastbergen (2003).

beacons deployed by Paull et al. (2010a) is not clear. The flow speeds recorded by Xu et al. $(2004,2013)$ would be insufficient to move the coarsest sediment (including boulder sized intraclasts and pebbles) found on the canyon floor. It is possible that the dilute and relatively thick supercritical flows documented by Xu et al. (2004) occur above a layer of dense fluidized coarse sediment of the type inferred by Paull et al. (2010a). However, the shape of their velocity profile suggests that they were not driven by fast motion of an underlying dense nearbed layer in these measurement locations, as velocities decline sharply towards the bed. Such an overlying dilute flow may be responsible for the thinner and finer sand layers seen by Paull et al. (2010a) at heights of up to $10 \mathrm{~m}$ above the canyon floor.

\subsubsection{Scripps and La Jolla Canyons, offshore California}

Scripps Canyon is a tributary of La Jolla Canyon, and both canyons have heads that are near the shoreline. These canyons are fed by clean sand moving within the long-shore transport cell through wave action. The processes that then move sand downslope within the heads of these canyons have been studied in considerable detail (Dill, 1964; Shepard and Dill, 1966; Dill, 1967, 1969; Shepard et al., 1969, 1977; Inman et al., 1976; Marshall, 1978; Paull et al., 2012).

As was the case for Monterey Canyon, these events can be powerful, occur with sub-annual frequency, and typically coincide with large wave heights. They also do not run-out for very long distances and did not exit the lower canyon (Shepard et al., 1969; Piper, 1970). The events in La Jolla and Scripps Canyon may be broadly similar to the stormtriggered events in the upper part of the Monterey Canyon (Paull et al., 2003, 2010a, 2010b; Xu et al., 2004; Xu et al., 2013) and the Hueneme and Mugu Canyons (Xu, 2010; Xu et al., 2010). However, at least one of the events in Scripps Canyon resulted from a slump (with a volume of $0.0001 \mathrm{~km}^{3}$ ) located in the side of the canyon near its head (Marshall, 1978). The uppermost part of Scripps Canyon in particular has steeper axial gradients $\left(>5^{\circ}\right)$ and head walls than the Monterey Canyon, and is in places a relatively narrow slot with overhanging walls. La Jolla Canyon has a shallower gradient of $1^{\circ}$, and also contains crescent shaped bedforms (Paull et al., 2011).

Inman et al. (1976) summarised monitoring efforts near the head of the Scripps Canyon in water depths of $\sim 65 \mathrm{~m}$. The events were typically associated with strong wave action that caused sand to be fed into the upper canyon. A flow velocity of $1.9 \mathrm{~m} / \mathrm{s}$ was recorded remotely in one instance, before the instruments were lost. Observations by divers after these events showed that almost all sand was lost from the upper canyon head, indicating that sand had flowed or slumped further down canyon. These flow events were powerful enough to bend a $2.5 \mathrm{~cm}$ thick steel rod that was bolted into bedrock at the side of the canyon (Inman et al., 1976). The divers reported that the sand sometimes remained partly liquefied (such that it could be penetrated by their arm) for up to 6 months after such an evacuation (Dill, 1964; Shepard and Dill, 1966). Bedrock exposed by the sand flows could have a polished appearance. Shepard et al. (1977) described three events at water depths of $\sim 200 \mathrm{~m}$ in La Jolla Canyon in 1972. Current meters recorded flow speeds (5 minute averages) of up to $50 \mathrm{~cm} / \mathrm{s}$ before the equipment was moved $\sim 500 \mathrm{~m}$ down canyon, and submersible dives subsequently observed a recently cut shallow channel in the uppermost canyon floor. The canyon-floor deposits were massive coarse sands that contained mud-clasts and thin sand layers occurred up to 50-100 m up the sides of the canyon (Shepard and Dill, 1966; Shepard et al., 1969). The facies are broadly similar to those documented in the axis and sides of the Monterey Canyon (Paull et al., 2010a).

Based on this monitoring, it was proposed that transport of sand occurred in dense and thin flows, rather than expanded and dilute turbidity currents (Shepard and Dill, 1966). This sand transport occurred by slow creep of sand (as shown by stakes that became tilted) or avalanching of individual sand grains on steep gradients of $20^{\circ}$ to $30^{\circ}$, and episodic evacuation of sand through slumps and dense 'rivers of sand' capable of carrying blocks (Shepard and Dill, 1966). Cores on the fan below suggest that long run out events that spilled out of the shallow fan valley are much less frequent (Shepard et al., 1969; Piper, 1970).

Paull et al. (2012) recently mapped the La Jolla canyon floor in very high resolution from water depths of 280 to $725 \mathrm{~m}$ using an AUV (Fig. 10). Crescentic bedforms are common, and resemble those seen Monterey Canyon (Paull et al., 2010a). These bedforms are 1-2 m high, have spacings of 20 to $100 \mathrm{~m}$, and angles of $\sim 15^{\circ}$ on their steeper down-slope side. The average gradient of canyon floor is remarkably uniform at $1^{\circ}$. The crescentic bedforms characteristically extend down from a master headscarp that defines their up-canyon termination (Fig. 10a, b). This master-scarp morphology suggests that the bedforms are formed by slumping of a liquefied layer near-bed sediment, most likely by a breaching process that migrates up-slope. This hypothesis is consistent with visual observations of the canyon floor made during the collection of sediment cores using a ROV-mounted vibracorer (Paull et al., 2012). A thin $(\sim 2 \mathrm{~cm})$ layer of cohesive mud on the sea floor cracked apart, and the underlying sand flowed for a short distance downslope (Fig. 10c; Paull et al., 2012; see their supplementary material for video footage). This behaviour suggests that the sand was partially or fully liquefied, most likely due to collapse of an initial looselypacked structure. Movement of the sand occurred within $\sim 2 \mathrm{~m}$ of the vibrating corer (Fig. 10). This type of behaviour has only been seen when ROV-vibracoring in areas of crescentic bedforms, suggesting that it is associated with development of these bedforms. It has been proposed that dense liquefied flows of sand would not be mobile on gradients of less than $\sim 5^{\circ}$ (Lowe, 1976, 1982). It appears that liquefaction of canyon-floor sand can occur on average gradients of $\sim 1^{\circ}$. The bedforms that then develop have gradients of $\sim 15^{\circ}$ on the down-slope facing 

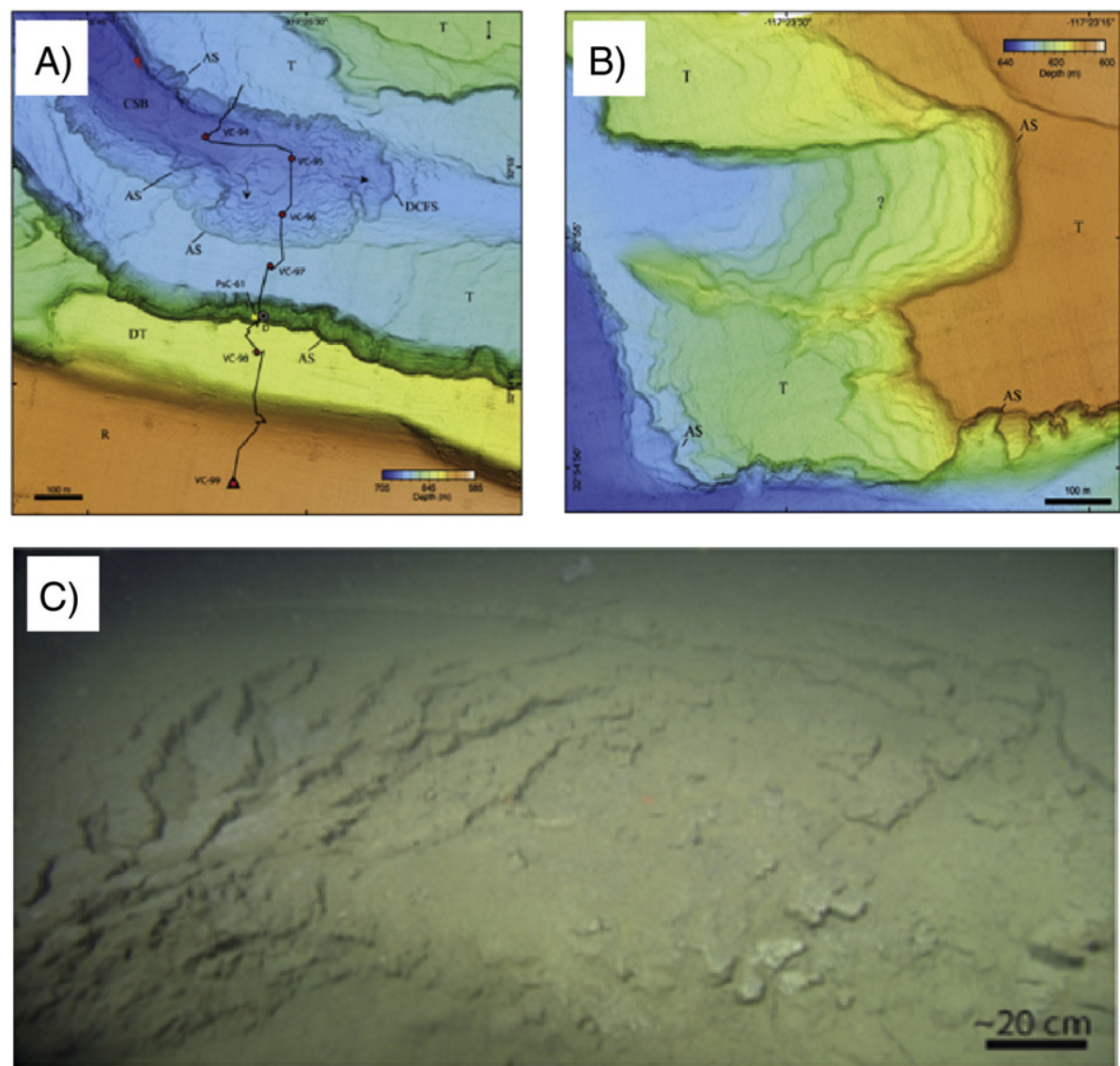

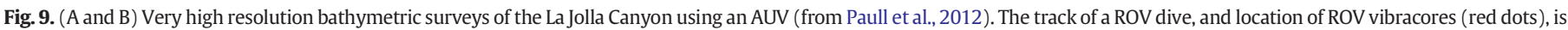

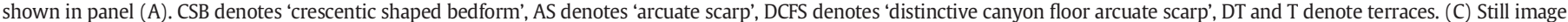

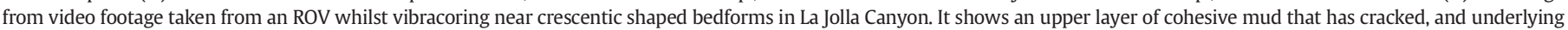
sand that is flowing. The image is from a location with an average gradient of $\sim 1^{\circ}$. See the supplementary material of Paull et al. (2012) for the entire video clip.

Event 1, 17 December 2002

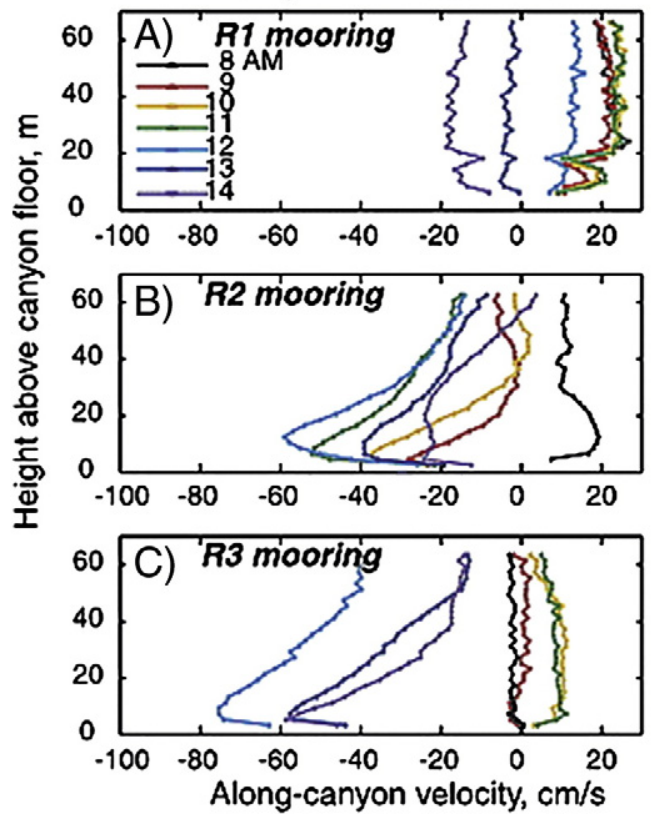

Event 2, 20 December 2002
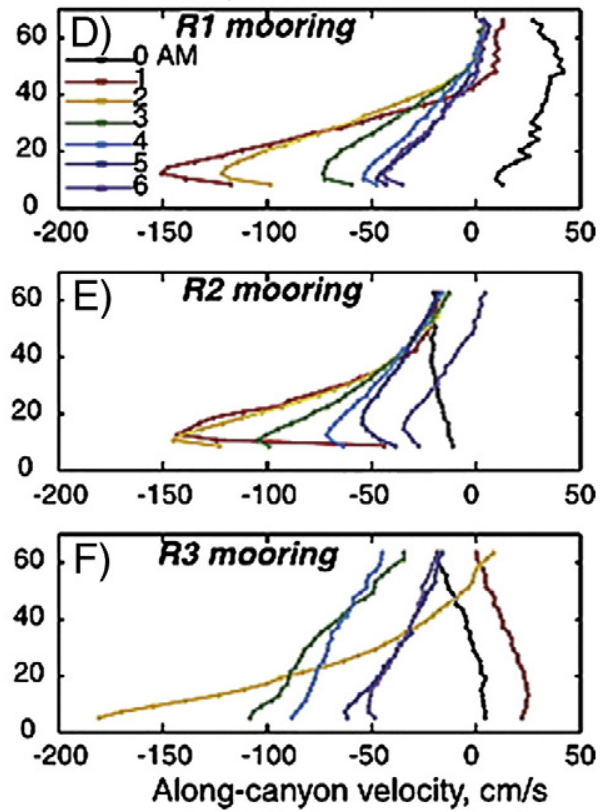

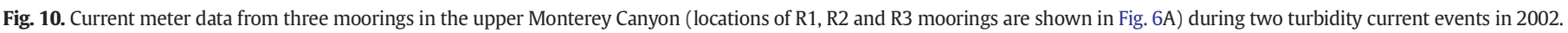

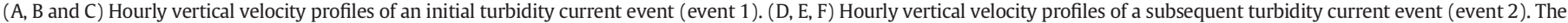

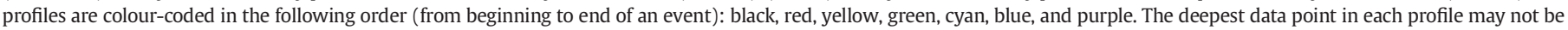
accurate because of acoustic interference from the canyon floor. Velocities are interpolated to a common, hourly time-base. Notice the different velocity scales for the two events. Figure from Xu et al. (2004). 
scarp, which may favour continued up-slope-migrating retrogressive breaching.

\subsubsection{Hueneme and Mugu Canyons, offshore California}

Xu et al. (2010) and Xu (2010) reported vertical velocity profiles for events in 2007 and 2008 in Hueneme Canyon and Mugu Canyon that are located to the north of the Santa Monica Basin. These measurements were made in $188 \mathrm{~m}$ and $179 \mathrm{~m}$ water depth near the head of these canyons, where the sea floor gradient is $2^{\circ}$. The events appear to be associated with storm-wave reworking of shelf sediment rather than river flooding (Xu et al., 2010).

These events must have been relatively dilute ( $\ll 5$ vol.\% sediment) to allow measurement with downward pointing ADCPs. A depth averaged sediment concentration of 0.33 vol.\% was calculated using a Chezy-type equation (Xu et al., 2010). The velocity profiles defined flows that were 15 to $25 \mathrm{~m}$ thick, with maximum velocities of up to $2.8 \mathrm{~m} / \mathrm{s}$ at $\sim 4 \mathrm{~m}$ above the sea floor. Flows typically lasted for $\sim 1 \mathrm{~h}$, but the turbid plume that they created could persist for up to $10 \mathrm{~h}$. Velocity time series showed that the maximum velocities sometimes occurred within a few minutes of the head arriving, after which the velocity decayed rapidly. However, in one case fast ( $>1 \mathrm{~m} / \mathrm{s}$ ) flow was sustained for $\sim 2 \mathrm{~h}$, with multiple peaks in velocity. The shape of the velocity profiles suggests supercritical flow (Xu, 2010, 2011), consistent with estimates of the Froude number based on flow thickness, density and velocity. An abrupt decline in flow velocity near the bed (Xu, 2011), suggests that these dilute flows were not being driven by faster moving dense near bed layers of sediment. Mugu Canyon also contains well developed crescent shaped bedforms of the type seen in Monterey Canyon.

\subsubsection{Eel Canyon, offshore California}

Seminal field data collected from the Eel continental margin, and other locations worldwide, have shown how resuspension of sediment by wave-action or tidal currents can play an important role in sediment transport across continental shelves (e.g. Sternberg et al., 1996; Ogston et al., 2000; Traykovski et al., 2000, 2007; Wright et al., 2001; Wright and Friedrichs, 2006). Storms that generate river flood discharge can also produce strong wave action on the shelf, especially when the river has a small drainage basin located adjacent to the coastline. Monitoring data from the continental shelf offshore from the Eel River showed how relatively thin $(<\sim 20 \mathrm{~cm})$ layers of fluid mud were formed due to wave action, which moved at speeds of a few tens of $\mathrm{cm} / \mathrm{s}$. These fluid mud layers had sediment volume concentrations of $\sim 0.4 \%$ to $~ 3 \%$, and produced muddy deposits were up to $15 \mathrm{~cm}$ thick on the mid to outer shelf (Wheatcroft and Borgeld, 2000). Sediment budgets indicate that a substantial fraction (up to $60 \%$ ) of the sediment transported across the shelf eventually flows off the shelf (Sommerfield and Nittrouer, 1999; Puig et al., 2003).

Monitoring in the uppermost part of Eel Canyon recorded very dilute (up to 0.004 vol.\% sediment) down-slope directed flows that were sustained for many hours, with a maximum speed of $78 \mathrm{~cm} / \mathrm{s}$ (Puig et al., 2003). These down-canyon flows were associated with large wave heights generated by storms, and did not coincide with floods of the Eel River, or earthquakes (Puig et al., 2003, 2004). Fluctuations in down-canyon flow velocity coincided with changes in pressure indicating that the down-canyon directed flows are also influenced by wave action. Significant cross-shelf transport of fluid mud layers did not occur at the same time as the down canyon events (Puig et al., 2004). The down-canyon flows were therefore either due to localised slope failure due to wave-induced liquefaction (Puig et al., 2004), or sediment resuspension from the bed by wave action, from a source closer to the canyon head.

\subsubsection{Nazaré Canyon, offshore Portugal}

In addition to sediment transport by tidal currents and nepheloid layers, dilute $(0.0004$ vol.\%) turbidity currents have been observed to reach water depths of 3300 to $4300 \mathrm{~m}$ in Nazaré Canyon (de Stiger et al., 2007; Martin et al., 2011). These down-canyon directed flows have reached speeds of up to $30-50 \mathrm{~cm} / \mathrm{s}$, and can last for several days. They typically (but not always) coincide with periods of large wave heights associated with storms. However, the fastest turbidity currents were not associated with the largest storm wave heights, and not all periods of large wave heights $(>4 \mathrm{~m})$ generated turbidity currents that reached these locations (de Stiger et al., 2007; Martin et al., 2011). Earthquakes with magnitudes of up to 5.4 failed to generate turbidity currents at these monitoring sites. These flows sometimes transported sand and were rich in organic material, producing deposits that were $\mathrm{mm}$ to a few $\mathrm{cm}$ thick in the lower canyon. However, sediment accumulation rates in the upper canyon can reach $2 \mathrm{~cm} /$ day (Arzola et al., 2008; Masson et al., 2010). These relatively dilute and slow moving flows infill Nazare Canyon and do not reach the Iberian Abyssal Plain. Distal cores show that the canyon is flushed by much more infrequent and powerful flows (Arzola et al., 2008) that are yet to be monitored.

\subsubsection{Hurricane Iwa, offshore Oahu, Hawaii, 1982}

A flow event occurred in a broad re-entrant on the open slope off Hawaii as Hurricane Iwa passed over and generated wave heights of up to $9 \mathrm{~m}$ (Dengler et al., 1984). Episodic movement of moorings, which weighed $30 \mathrm{~kg}$, occurred over a 4 hour period and resulted in up to $2.4 \mathrm{~km}$ of downslope displacement. Flow speeds of up to $2 \mathrm{~m} / \mathrm{s}$ were inferred from moorings. A series of cable breaks indicate that this flow reached at least $1800 \mathrm{~m}$ water depth, but the timing of cable breaks was not documented with enough precision to estimate flow speeds (Tsutsui et al., 1987). This flow is inferred to have resulted from slope failure due to wave loading, although it is unclear whether offshore-directed flow was associated with set up due to a storm surge, or whether sediment resuspension by large waves also played a role in triggering the flow (Dengler et al., 1984).

\subsection{Flows in systems associated with rivers}

This section describes marine observations from delta or fan systems that are fed with sediment by rivers. This can occur through slope failure of rapidly deposited sediment, or by direct plunging of hyperpycnal river floodwater. Evidence for relative importance of these two triggering processes is outlined here, and discussed further in Section 7.1.3.

\subsubsection{Zaire Canyon-channel system, West Africa, 2001, 2004 E' 2009-10}

Khripounoff et al. (2003) described a flow event in the Zaire deepsea channel in March 2001 (Fig. 10). Two sets of instruments were deployed in their study at $4000 \mathrm{~m}$ water depth; in the channel axis (gradient $0.17^{\circ}$ ), and $13 \mathrm{~km}$ away on the adjacent levee. The instruments originally placed within the channel axis were subsequently found floating on the ocean surface after the mooring cable broke immediately above the sea floor. The current meter located originally $30 \mathrm{~m}$ above the channel axis was badly damaged, but the current meter located $150 \mathrm{~m}$ above the channel floor recorded a flow velocity of $1.21 \mathrm{~m} / \mathrm{s}$ (Fig. 10). This velocity is a vector average over one hour, and the maximum velocity may have been significantly higher for a short period within that hour. Tilting of the current meter by the current also most likely occurred and led to underestimation of maximum down-channel velocity. The sediment trap located $40 \mathrm{~m}$ above the channel floor was badly damaged and full of sediment rich in terrestrial organic material. Turbidity meters and sediment traps at the levee site recorded the event, but there was a significant delay (up to 3 days) for the flow to reach that location from the channel. This event did not coincide with flooding of the Zaire River.

Another event occurred along the Zaire submarine channel in January 2004 (Vangriesheim et al., 2009) after two years of quiescence (Fig. 10). This event had an average frontal speed of $3.5 \mathrm{~m} / \mathrm{s}$ on a gradient of $0.23^{\circ}$ for $240 \mathrm{~km}$ along the Zaire channel between sites located in water depths of $3420 \mathrm{~m}$ and $4070 \mathrm{~m}$. The flow then moved with an 
average frontal speed of $0.7 \mathrm{~m} / \mathrm{s}$ across a gradient of $\sim 0.1^{\circ}$ for a further $380 \mathrm{~km}$ to the termination of the channel, between water depths of $4070 \mathrm{~m}$ and $4790 \mathrm{~m}$ (Fig. 10). Current meters measured speeds of 0.4 to $0.96 \mathrm{~m} / \mathrm{s}$ at heights of 60 to $190 \mathrm{~m}$ above the channel floor, with each measurement being an average for one hour. Whether this event was related to flooding of the Zaire River is unclear because suitable hydrograph data is unavailable and the event could have originated due to failures of the canyon walls or rapidly deposited sediment at the mouth of the canyon (Vangriesheim et al., 2009).

Cooper et al. (2013) documented 11 flows in 2009-10 at 2000m water depth within the Congo Canyon. These unusually detailed ADCP time series show that flows were prolonged with durations of up to 6-10 days. This is consistent with the long delay before flow arrived at the levee station of Khripounoff et al. (2003). Peak flow velocities of up to $2.5 \mathrm{~m} / \mathrm{s}$ occurred just 1-3 minutes behind the flow front, although speeds of up to $\sim 1 \mathrm{~m} / \mathrm{s}$ could be prolonged for several days. Peak velocities occurred less than $\sim 5 \mathrm{~m}$ from the bed. Flow thicknesses were between 10-to-120m, with a correlation between faster and thicker flows. The long flow durations may result from a sustained source, although the low sediment concentration of the Zaire River makes it unlikely to plunge during sustained floods. An alternative hypothesis is that long durations result from a faster flow front running away from a slower moving tail, as the flow travelled $>125 \mathrm{~km}$ from the river mouth.

\subsubsection{Typhoon Morakot, Taiwan, 2009}

Two submarine density flow events were associated with Typhoon Morakot that produced $2.7 \mathrm{~m}$ of rainfall over 3 days, including some of the heaviest rainfall ever recorded in a 24 hour period (Fig. 11; Kao et al., 2010; Carter et al., 2012). This resulted in flooding along the Gaoping River in SE Taiwan, whose mouth is located less than $1 \mathrm{~km}$ from Gaoping submarine canyon (Fig. 11; Liu et al., 2006). Two offshore cable breaks occurred shortly after the peak flood discharge on August 9th (Carter et al., 2012; Gavey, 2012). These cable breaks could

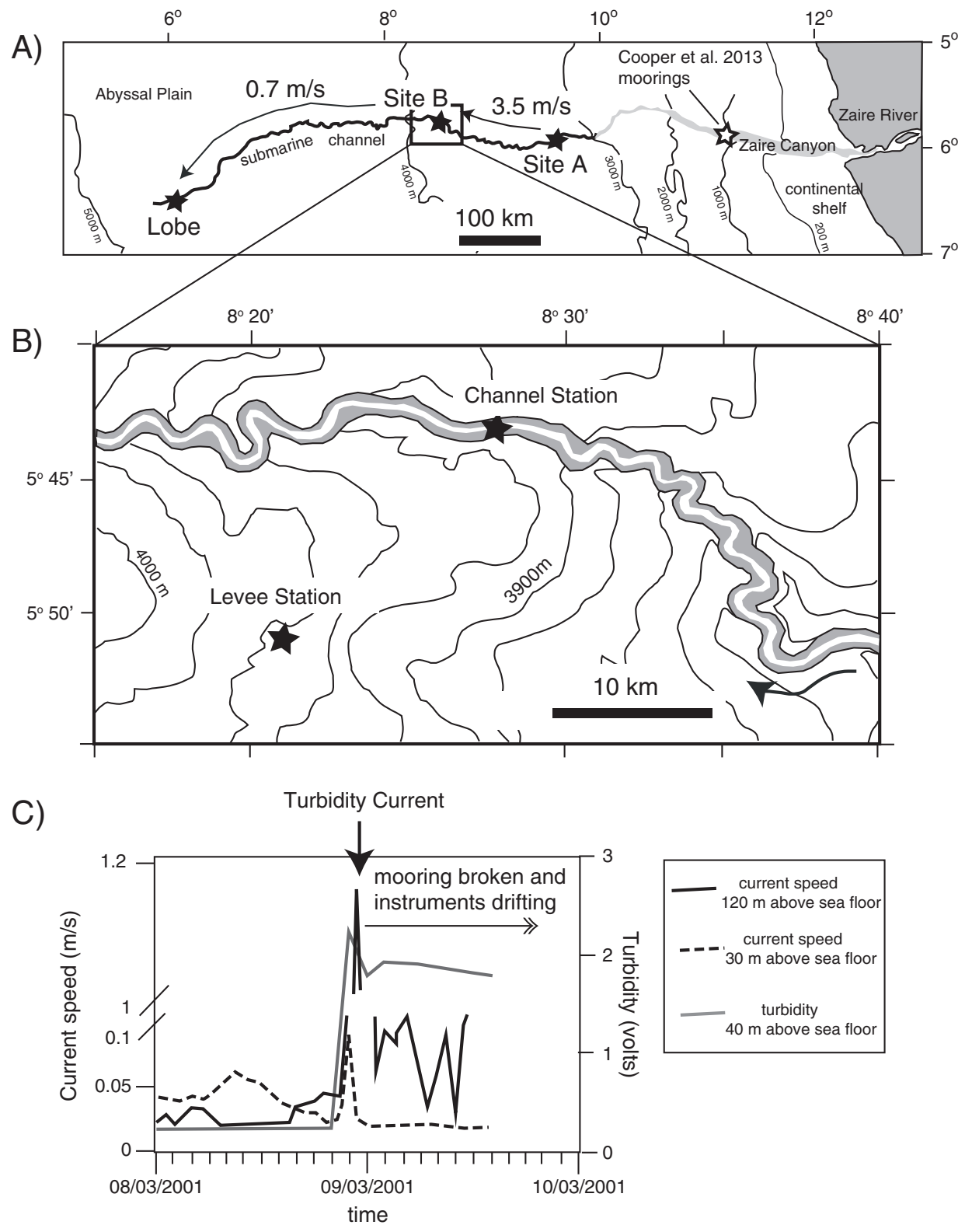

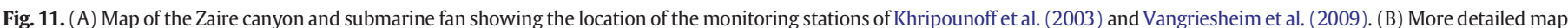

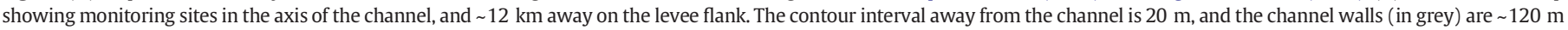

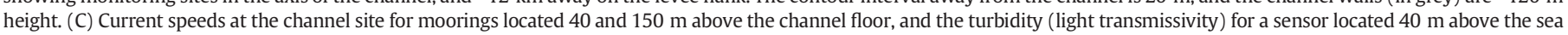
floor in the channel. Figure from Khripounoff et al. (2003). 
have resulted from plunging of hyperpycnal floodwater, although the preceding $\sim 48 \mathrm{~h}$ of floodwater discharge had not caused any cable breaks, despite probably having sufficiently high sediment concentration to plunge (Carter et al., 2012). Alternatively, this event may have been generated by failure of rapidly deposited sediment in the canyon head. If these two cables broke at the onset of the submarine flow (see Section 4.1.3), they recorded a frontal flow velocity of $16.6 \mathrm{~m} / \mathrm{s}$ on a gradient of $\sim 1.1^{\circ}$ (Carter et al., 2012; Gavey, 2012).

Six other cables broke $~ 3$ days after the peak flood discharge, at a time when the flood had subsided and floodwater was not plunging (Carter et al., 2012). The first of these cable breaks was $150 \mathrm{~km}$ offshore, and subsequent cable breaks indicate flow speeds of $10.3 \mathrm{~m} / \mathrm{s}$ and $7.5 \mathrm{~m} / \mathrm{s}$ on gradients of $0.4^{\circ}$ and $0.2^{\circ}$ (Fig. 11). There were no significant ( $>\mathrm{M}_{\mathrm{W}} 2.0$ ) earthquakes throughout this period, so this failure was not due to earthquake shaking. This flow is interpreted to have been triggered by failure of rapidly deposited sediment in the canyon head (Carter et al., 2012). Wave heights of up to $10 \mathrm{~m}$ were recorded nearby on the 7th to 10th of August. Although failure postdates the strongest wave action (Hale et al., 2012), it may have led to delayed failure through cyclic loading. This second flow travelled for over $370 \mathrm{~km}$ to water depths of $4000 \mathrm{~m}$ (Carter et al., 2012; Gavey, 2012). As the flow was still travelling rapidly at the final cable breaks, it most likely travelled significantly further (Fig. 11).

On the 14th and 15th of August 2009, Kao et al. (2010) documented an $250 \mathrm{~m}$ thick layer of anomalously warm, low-salinity water at depths of 3000 to $3700 \mathrm{~m}$ in locations $\sim 180 \mathrm{~km}$ offshore. The layer represents an intrusion of coastal and river flood water. It contained sediment volume concentration of $\sim 0.007$, allowing it to be stably stratified. Kao et al. (2010) proposed that this layer of warmer and fresher water was generated by plunging of hyperpycnal river floodwater, representing $\sim 8 \%$ of the total rainfall during Typhoon Morakot, which then entrained further warm coastal water. The timing of their measurements means that this layer of water could result either from the initial hyperpycnal turbidity current on August 9th, or the later most powerful slump-triggered turbidity current on August 12th and 13th (Fig. 11).

This dataset is important because it is the first to document directly that powerful flows associated with river floods can reach the deep ocean (Carter et al., 2012; Gavey, 2012). However, the most powerful second flow was generated by failure of rapidly deposited sediment in the canyon head, and not directly by plunging of hyperpycnal flood waters.

\subsubsection{Typhoon Kalmaegi, Taiwan, 2008}

Liu et al. (2012) used two adjacent moorings with sediment trap, current meter, upward looking ADCP, and a series of thermometers to events in the uppermost part of Gaoping Canyon associated with flooding of the Gaoping River during Typhoon Kalmaegi in July 2008. The turbidity current lasted $\sim 14 \mathrm{~h}$ and was related directly to plunging of the flood water. However, a lack of cable breaks further downslope suggests that this event did not generate a powerful, long run-out turbidity current as seen in 2009. The event waxed and waned, such that the initial stages were associated with relatively slow flow velocities that increased to reach a peak velocity of $1.6 \mathrm{~m} / \mathrm{s}$ after $\sim 4 \mathrm{~h}$, which was measured $56 \mathrm{~m}$ above the bed. An influx of water that was up to $2{ }^{\circ} \mathrm{C}$ warmer than surrounding seawater was observed during and after the peak velocity, by sensors that were $>40 \mathrm{~m}$ above the bed. A sediment trap located $42 \mathrm{~m}$ above the bed collected $\sim 10 \mathrm{~cm}$ of sediment during the event. This sediment was $40 \%$ sand and was rich in terrestrial organic carbon. The upper part of the flow must have been relatively dilute to allow an upward pointing ADCP (positioned $30 \mathrm{~m}$ above the bed) to penetrate the overlying flow. It had an estimated time-averaged sediment concentration of $\sim 0.17 \mathrm{vol} . \%$ at a height of $42 \mathrm{~m}$ above the bed. The layer of warmer water within the upper canyon was up to $\sim 150 \mathrm{~m}$ thick. This study shows that plunging of river flood water can generate thick and relatively dilute turbidity currents within the upper parts of submarine canyons, and that these events may transport large amounts of terrestrial organic carbon and fine sand.

\subsubsection{Cable breaks off rivers that discharge directly into a canyon}

Submarine cables that extend across Zaire Canyon in water depths of 500 to $2000 \mathrm{~m}$ have been broken repeatedly since 1886, with an estimated 60 breaks per century (Heezen et al., 1964; Heezen and Hollister, 1971). The Zaire River enters straight into the head of the Zaire Canyon without an intervening shelf. Most of the breaks occurred during months of the year that coincide with higher discharge from the Zaire River (November to February and April to May; Heezen and Hollister, 1971 their figure 8.27). This led Heezen et al. (1964) and Heezen and Hollister (1971) to infer that the flow events that broke the cables coincided with Zaire River floods on most occasions. However, increased wave action across the broad continental shelf that surrounds the upper canyon may also transport sediment into the upper canyon during these parts of the year.

Cable breaks have been reported off other rivers that discharge across a narrow shelf or directly into a submarine canyon. Heezen and Hollister (1971) reported that submarine cables 30 to $90 \mathrm{~km}$ from the Magdalena River mouth were broken 16 times in the 37 years after 1930, and that one of these events in 1935 coincided with collapse of jetties being built at the river mouth. Most of the cable breaks coincided with high river discharge, but some were ascribed to longshore drift and storm remobilisation of sediment (Romero-Otero et al. 2010). Like the Zaire River, the Magdalena River discharges directly into a canyon head.

Many small mountainous rivers discharge along the southern shore of the Gulf of Corinth, building fan deltas directly into deep water (Iatrou et al., 2007). Numerous cable breaks occurred seaward of these rivers. Heezen et al. (1966) reported that the rivers carry, during times of flood, a heavy load of sediment and debris. There have been many cases when branches, twigs and brushwood of various kinds have been found wrapped around broken cables. Most of the cable failures occurred during the relatively wet and stormy winter months of November, December and January.

\subsubsection{Var Canyon, Mediterranean, 2005-2010}

In addition to the previously described 1979 Nice Airport event triggered by slope failure, monitoring of the Var Canyon has documented much slower and shorter run-out events, which are very dilute (Khripounoff et al., 2009, 2012). A total of six events were observed during a two year period in 2005-2008, with three further events observed during a 4 month period in 2008-2009. These studies used sediment traps ( $20 \mathrm{~m}$ above the sea floor) and current meters ( $30 \mathrm{~m}$ above the sea floor) at sites ranging from 510 to $2350 \mathrm{~m}$ water depth (Fig. 4). ADCPs at three sites (Khripounoff et al., 2012) provided some of the few velocity profile time series available for submarine turbidity currents (cf., Xu et al., 2010; Xu, 2011; Hughes Clarke et al., 2012).

Several of these flows coincided with floods from the Var River, and these flows were most likely initiated by discharge of hyperpycnal river floodwater (Khripounoff et al., 2012; Fig. 4). These flood-related events reached maximum speeds of 0.2 to $0.7 \mathrm{~m} / \mathrm{s}$, and lasted for between $8 \mathrm{~h}$ and 2.5 days. Their thickness could reach $130 \mathrm{~m}$, and some comprise a series of irregular pulses spread over two days (Khripounoff et al., 2012). Layer averaged concentrations, inferred using an approach based on the Chezy equation (Section 7.2) were 0.003 vol.\%. This dilute sediment concentration is consistent with the ability of the ADCPs to penetrate the flow, and sediment fluxes recorded by the sediment trap were $600 \mathrm{~g} / \mathrm{m}^{2} /$ day. This flux is equivalent to a deposition rate of 0.3 to $0.5 \mathrm{~mm}$ day $^{-1}$ assuming a deposit density of between 1300 and $1800 \mathrm{~kg} / \mathrm{m}^{3}$. The events most likely produced fine-grained deposits that were only a few mm thick, similar to those described by Mas et al. (2010). This suggests that plunging of river water during floods can generate weak, dilute and expanded submarine flows that may reach the base of the continental slope. 
The timing of at least two of the nine Var Canyon events did not coincide with river flooding and were therefore not triggered by river flood discharge (Khripounoff et al., 2009, 2012). Instead they were inferred to result from failures within the canyon. These flows reached speeds of up to $>0.85 \mathrm{~m} / \mathrm{s}$, and their thicknesses ranged from 30 to $100 \mathrm{~m}$. They were also dilute, with depth integrated sediment concentrations of $\sim 0.006$ vol.\% inferred from the Chezy equation. These flows could also be penetrated by the ADCPs, and sediment accumulation rates recorded by sediment traps located $20 \mathrm{~m}$ above the sea floor were $\sim 0.15 \mathrm{~mm} /$ day (Khripounoff et al., 2012).

\subsubsection{Bute Inlet, British Columbia, Canada, 1985-86, 1988-89, and 2008-10}

Turbidity currents in Bute Inlet, British Colombia were monitored using current meters, sediment traps and vane detectors in 1985 to 1986 (Fig. 12; Prior et al., 1987; Zeng et al., 1991; Zeng and Lowe, 1997). Three sites were instrumented in water depths of $270 \mathrm{~m} \mathrm{(6} \mathrm{km}$ from the channel head), $425 \mathrm{~m}(22 \mathrm{~km})$ and $520 \mathrm{~m}(32 \mathrm{~km})$ along a channel axis. Current meters were located $4 \mathrm{~m}$ above the sea floor and recorded average velocities over 20 minute periods, together with an instantaneous velocity every $20 \mathrm{~min}$. The sediment traps were suspended 6 to $7.5 \mathrm{~m}$ above sea floor, whilst a series of vanes were located at different heights on the moorings. The vane detectors recorded periods of flow faster than $50 \mathrm{~cm} / \mathrm{s}$. Prior et al. (1987) reported that relatively infrequent longer run out flows occur, together with more frequent short run-out flows, and that both types of flow can be associated with flood discharge due to spring snowmelt from the Homathko and Southgate rivers.

An average frontal flow speed of $3.35 \mathrm{~m} / \mathrm{s}$ was recorded on a mean slope of $0.7^{\circ}$ between the first two measurement sites (Fig. 12). The average frontal flow speed decreased to $0.75 \mathrm{~m} / \mathrm{s}$ on a gradient of $0.58^{\circ}$ between the second and third sites. The vanes recorded flow that was $32-40 \mathrm{~m}$ thick at the first site, $27-32 \mathrm{~m}$ thick at the second site, and 7-12 m thick at the third site. Sediment traps showed that sand was carried 6.5 to $7 \mathrm{~m}$ above the sea floor. The trap closest to source contained coarse sand layers that were up to $47 \mathrm{~cm}$ thick, with
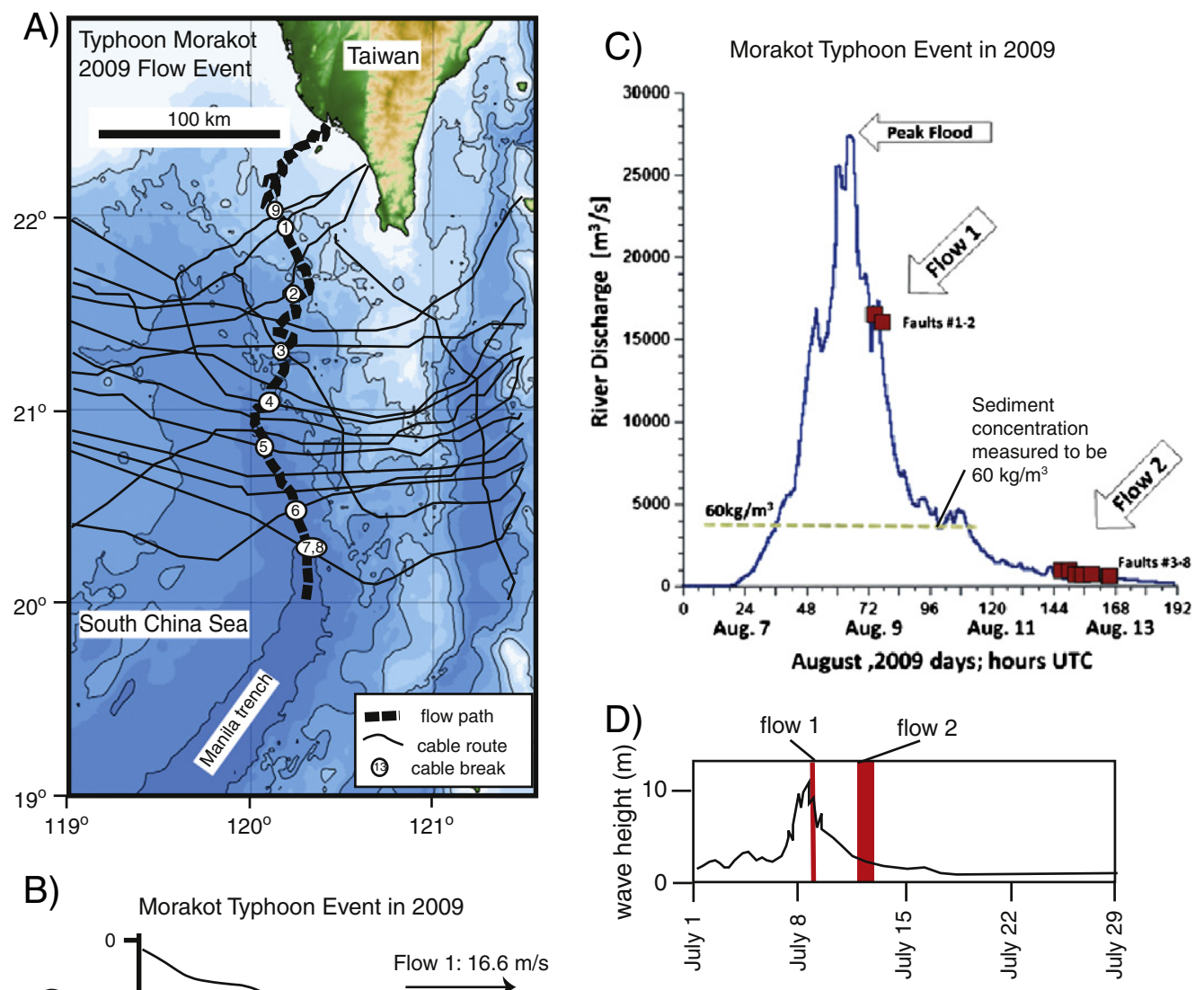

B) Morakot Typhoon Event in 2009

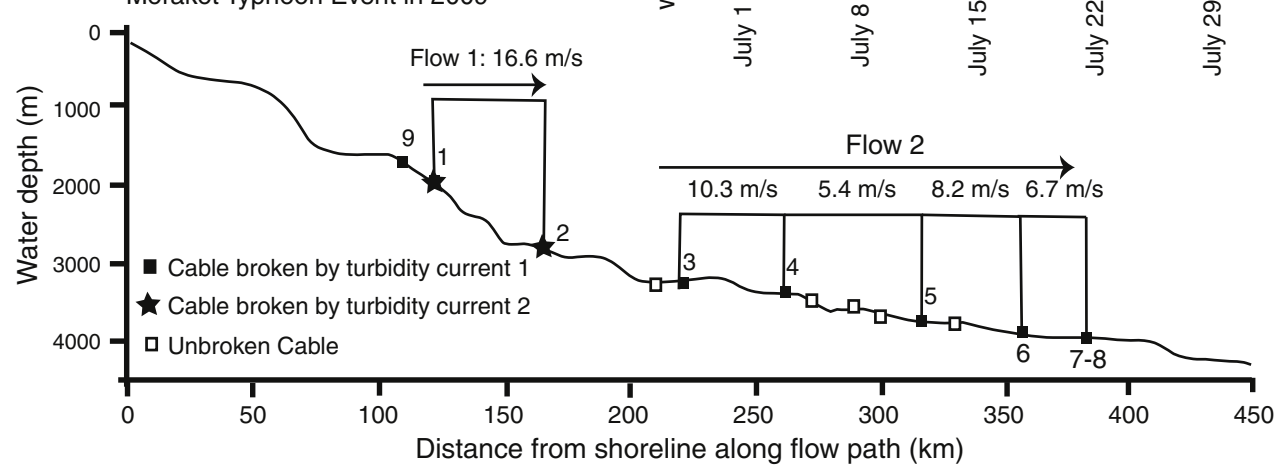

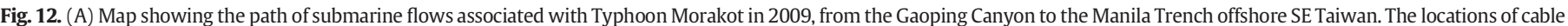

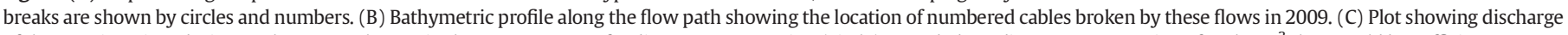

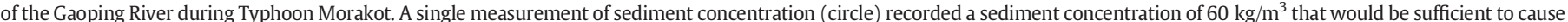

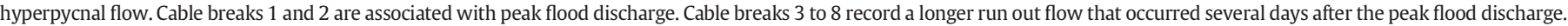

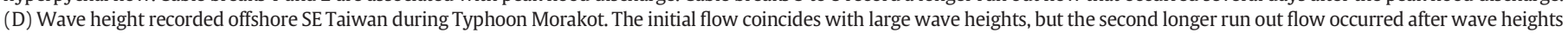
had waned. Parts A-C are from Carter et al. (2012). Part D from Hale et al. (2012). 
thinner layers of finer sand at the second trap site. The distal trap included a layer of muddy sand with organic fragments, which was $18 \mathrm{~cm}$ thick. These flows ran out for at least $32 \mathrm{~km}$ and most likely for 40 to $50 \mathrm{~km}$ into the fjord, and were therefore able to transport sand for several tens of kilometres. Equipment deployed in Bute Inlet sustained considerable damage during the course of the study, and instrument packages were found to have moved up to $890 \mathrm{~m}$ during flow events.

A turbidity meter was subsequently deployed in Bute Inlet in 1988-89, at a location just outside the main channel, $\sim 25 \mathrm{~km}$ from the Homothko River Delta (Fig. 12a; Bornhold et al., 1994; Ren et al., 1996). In order to overspill the channel, these relatively long run out flows must have been several tens of metres thick. Thirty five turbidity events were recorded, often with clusters of multiple events occurring within a few hours of each other. Turbidity currents tended to be associated with periods of higher river discharge, such that $80 \%$ of the events occurred when river discharge exceeded $\sim 300 \mathrm{~m}^{3} / \mathrm{s}$ (Fig. 12C). However, not all events were associated with individual flood peaks, and turbidity currents often lagged flood peaks by one or more days (Fig. 13C; Bornhold et al., 1994).

Repeated swath multibeam mapping of Bute Inlet has documented significant morphological changes in the main channel during a period of 2.5 years, between 2008 and 2010. Erosion and deposition caused changes in elevation of more than $5 \mathrm{~m}$ along 25\% of the main channel (Conway et al., 2012). Crescentic bedforms appear to extend for several kilometres along the floor of the main channel.

\subsubsection{Knight Inlet, British Columbia, Canada, 1991-92}

A similar turbidity meter to that used in Bute Inlet was also deployed in Knight Inlet for one year, where it recorded 39 turbidity current events at a location just outside the main channel that was over $10 \mathrm{~km}$ from the fjord head delta. These turbidity current events again tended to occur in clusters, and were generally associated with periods of elevated river discharge. As was the case in Bute Inlet, the turbidity currents were often not coeval with individual flood peaks (Bornhold et al., 1994; Ren et al., 1996). The timing of long (>10-25 km) run-out events in Bute and Knight Inlets led Bornhold et al. (1994) to propose that the turbidity currents were primarily triggered by delta front slope failures rather than plunging of hyperpycnal river flood discharge. These authors suggested that sediment that had accumulated in mouth bars was swept by floods onto the steeper delta front. This rapidly deposited sediment then failed generating the turbidity currents, with failure sometimes occurring days after the flood that deposited the sediment on the delta front (Bornhold et al., 1994; Ren et al., 1996). Repeated multibeam mapping of Knight Inlet showed that erosion and deposition produced significant (in excess of $5 \mathrm{~m}$ ) changes in elevation along $20 \%$ of the resurveyed main channel between 2008 and 2010 (Conway et al., 2012).

\subsubsection{Squamish River delta, Canada, 2004-12}

Brucker et al. (2007) and Hughes Clarke et al. (2009, 2012) used unusually detailed repeated bathymetry surveys to document the evolution of the Squamish River delta. Initial surveys in 1973 and 1990, were followed by 9 surveys between 2004 and 2009, and 93 surveys every 1-3 days in a 10 month period during 2011. The Squamish River discharges directly onto a steep $\left(5^{\circ}\right.$ to $\left.8^{\circ}\right)$ delta front. The lack of a mouth bar indicates efficient transport into deeper water (Fig. 13). Three active channels extend for 1 to $2 \mathrm{~km}$ to water depths of $\sim 110 \mathrm{~m}$, with the upper $0.3 \mathrm{~km}$ of the northern channel comprises a series of tributary gullies (Fig. 14; Hughes Clarke et al., 2009, in press). A lobe of active deposition extends for $\sim 0.7 \mathrm{~km}$ beyond each channel to water depths of $\sim 170 \mathrm{~m}$ (Fig. 13). The lobes have a gradient of $\sim 3^{\circ}$. An upward pointing Doppler current profiler (ADCP) and optical backscatter probe were places on the distal fringe of the northern lobe, and took measurements every $30 \mathrm{~s}$. The ADCP was deployed for 80 days, and mounted initially $50 \mathrm{~cm}$ above the sea floor, with the first ADCP measurement made $2.1 \mathrm{~m}$ above the bed. The ADCP profiler recorded 20 events that ran out across the lobe from the northern channel (Fig. 14; Hughes Clarke et al., 2012). These flows on the lobe were typically 5 to $15 \mathrm{~m}$ thick, had peak velocities of $\sim 50 \mathrm{~cm} / \mathrm{s}$ and durations of one hour.

Most events occurred over the summer period when snow-melts contribute to high discharges from the Squamish River (Fig. 13; Hughes Clarke et al., 2012). Some events coincided with individual peak river discharge events, but many did not (Hughes Clarke et al., 2012; Fig. 14A). The events could be subdivided into two types (Hughes Clarke et al., 2012, in press). More powerful events are triggered by relatively large $\left(<0.00015 \mathrm{~km}^{3}\right)$ failures of the rapidly prograding, steep $\left(40^{\circ}\right)$ delta lip. Two of these lip-failures coincided with unusually low tides, whilst three later events coincided with surges in river discharge (Hughes Clarke et al., 2012, in press). These events reached lobes at the end of the $2 \mathrm{~km}$ long channels on the delta-front, with the largest failure leading to burial of an ADCP moored on the lobe. Lip failures that coincided with pulses in river discharge may be due to increased rates of lip progradation, or increased shearing of bed by flood flow. Lip-failure can also be triggered by low tides, perhaps aided by the expansion of gas in the sediment (Christian et al., 1997). Sediment deposition almost completely refills the scars within a year (Hughes Clarke et al., 2009).

The second type of event was less powerful but much more frequent, with many tens of events each year. It involved motion of crescent shaped bedforms with concave down-slope crests that are well developed in all three channels on the delta front (Brucker et al., 2007; Hughes Clarke et al., 2009, 2012). In some cases, two channels were active during the same event. The bedforms begin at the shelf break and extend down all three channels (Hughes Clarke et al., 2009, 2012), and migrated upslope in a similar fashion to Monterey Canyon (Paull et al., 2010a). Upslope migrating bedforms extend across all three lobes, where they have crests that are less concave (Fig. 13; Hughes Clarke et al., 2012). Bathymetric changes were often restricted to the base of these $\sim 5 \mathrm{~m}$ deep channels, suggesting that the powerful parts of these flows were less than $5 \mathrm{~m}$ thick (Hughes Clarke et al., 2012).

Some events in this channel failed to reach the ADCP. These events caused bedforms to migrate for $>10 \mathrm{~m}$ in the channels, where they must have been relatively powerful. The lack of a signal at the ADCP site suggests that they abruptly decelerated over a distance of $<500 \mathrm{~m}$. The maximum flow speed recorded by the ADCP was $1.5 \mathrm{~m} / \mathrm{s}$, but maximum speeds were typically $\sim 0.5 \mathrm{~m} / \mathrm{s}$ during single events (Fig. 14; Hughes Clarke et al., 2012). The flow events lasted for less than one hour, although a turbid plume of sediment could then persist for up to $7 \mathrm{~h}$ (Fig. 14). The ADCP data show that flows were 10 to $40 \mathrm{~m}$ thick by the time they reached the end of the lobe. Backscatter data from the swath bathymetry show how dilute surface, interflows, and sea floor hugging flows were generated in some events (Fig. 14; Hughes Clarke et al., 2012). These data show that the upper parts of the events were relatively dilute, which is confirmed by optical backscatter profiles that record sediment concentrations up to $\sim 0.001$ vol.\%. Saturation of the optical probe indicates that concentration sometimes exceeded this value (Fig. 15; Hughes Clarke et al., 2012), but penetration of the EM710 multibeam sonar through the water column, suggests that sediment concentrations were $\ll \sim 5$ vol.\% (Hurther et al., 2011). The ADCP was buried for $\sim 20$ days, and then exhumed by the flows. However, the ADCP continued to record data after being exhumed (Hughes Clarke et al., 2012).

\subsubsection{Fraser River delta, Canada, 1994-2012}

The Fraser River delta is being formed offshore from the largest river system draining the Canadian Pacific coast (Fig. 15; Kostaschuk et al., 1992; Hart et al., 1992, 1998; Hill, 2012). Published direct monitoring data comprise repeated bathymetric surveys (Hill, 2012). The delta is fed mainly by fine sand, as a result of dredging discharge and fluvial transport by the Fraser River. The lack of mouth bars shows that this 

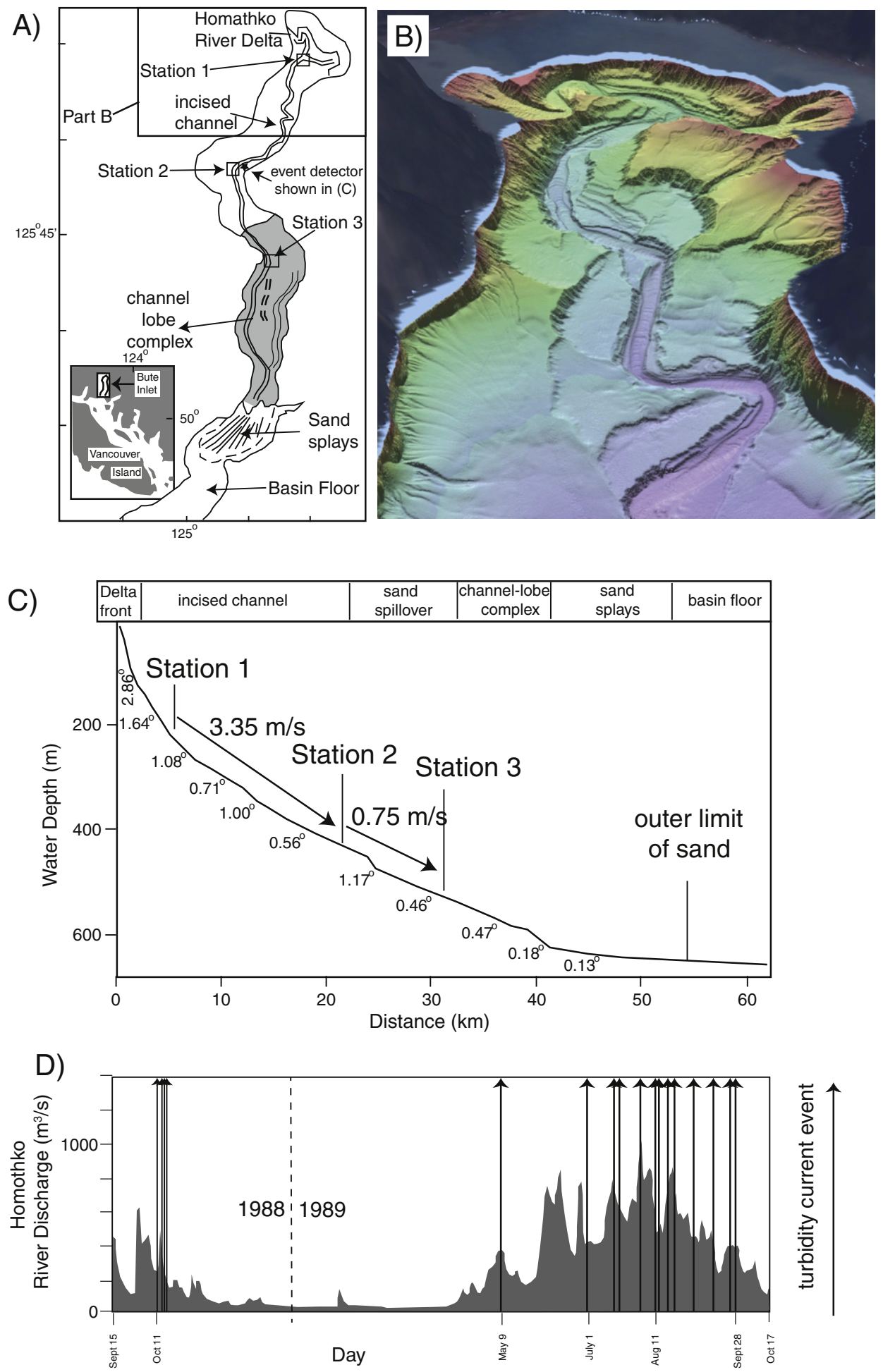

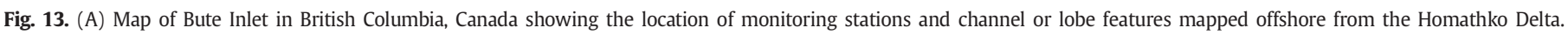

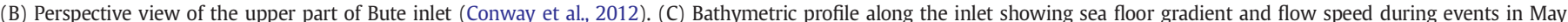

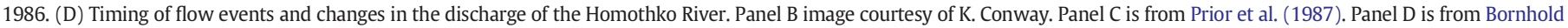
et al. (1994) their Fig. 3.

sand is transported efficiently into deeper water. The delta-fan system comprises a network of tributary channel on the steep $\left(\sim 1.3^{\circ}\right.$ to $5^{\circ}$ but $>20^{\circ}$ locally) delta front, which extend for $\sim 1 \mathrm{~km}$ to depths of $\sim 80 \mathrm{~m}$ (Fig. 15). They coalesce into the main channel that extends for a further $4 \mathrm{~km}$ to depths of $\sim 200 \mathrm{~m}$ and has a gradient of $\sim 1.5^{\circ}$, beyond which a second intermittent channel is cut into an $\sim 4 \mathrm{~km}$ lobe of high backscatter deposits on gradients of $\sim 13^{\circ}$ (Fig. 15; Kostaschuk et al., 1992; Hart et al., 1992, 1998; Hill, 2012).

At least five major $\left(\sim 10^{6} \mathrm{~m}^{3}\right)$ slope failures have occurred, most recently in 1985 at the head of a tributary channel (Hart et al., 1992). Smaller volume $\left(\sim 10^{5} \mathrm{~m}^{3}\right)$ failures also produced arcuate scarps mapped at the tributary heads, and changes of bathymetry (Hill, 2012). It is not 

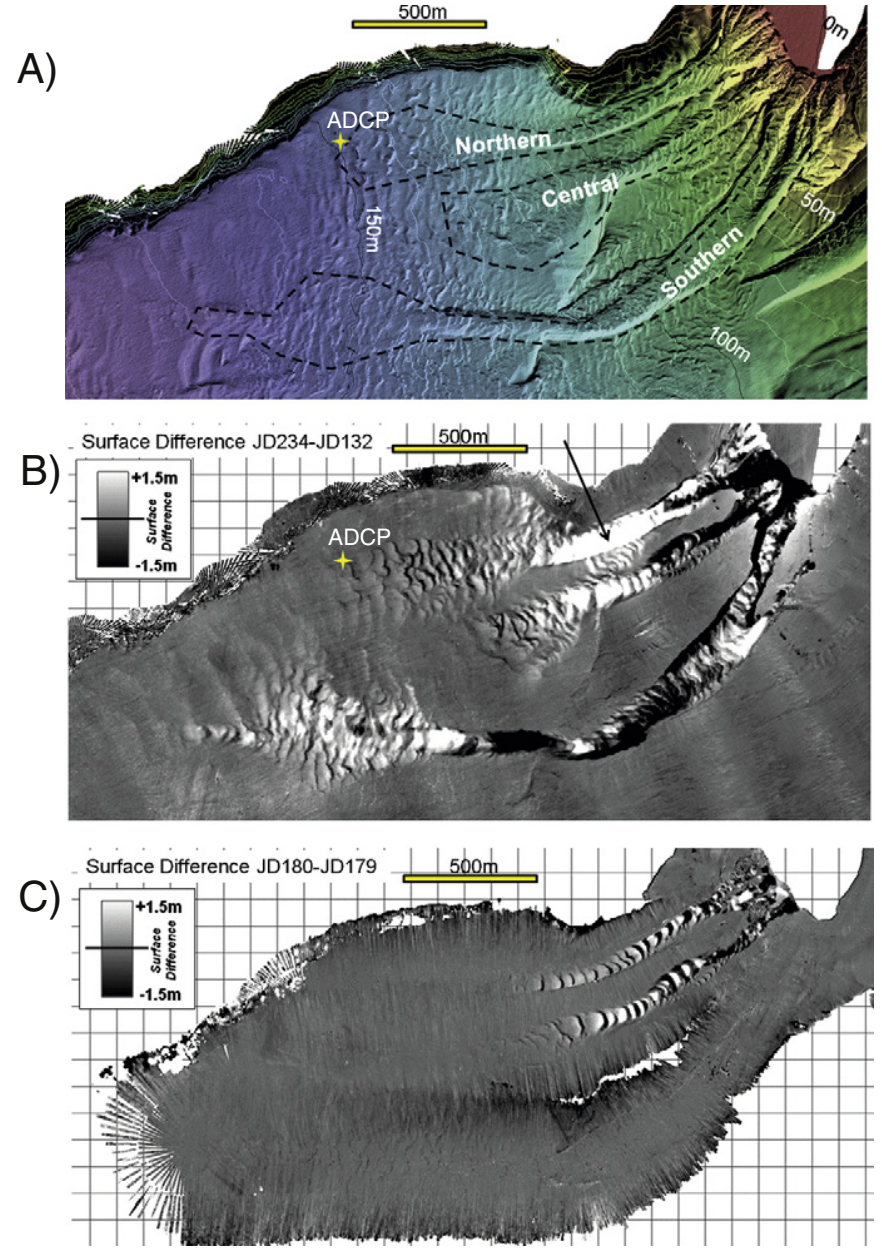

Fig. 14. (A) Bathymetric map of the three active channels on the Squamish River prodelta, British Colombia. Yellow star shows the position of Acoustic Doppler Current Profiler (ADCP). (B) Map showing the cumulative bathymetric difference observed between surveys on May 2nd and August 22nd 2011. The maximum thickness of deposition is $8 \mathrm{~m}$, and the maximum depth of erosion is $12 \mathrm{~m}$. Grey scale shows differences between +1.5 and $-1.5 \mathrm{~m}$. Arrow indicates the location of a sediment plug moving down the northern channel. (C) Map showing the cumulative bathymetric difference observed during a period of $24 \mathrm{~h}$. The water column imaging associated with the second survey is presented in Fig. 15b. All parts of the figure are from Hughes Clarke et al. (in press).

known whether river water plunges to form hyperpycnal flows, but surface plumes of hypopycnal discharge can carry sand for up to $1 \mathrm{~km}$ offshore (Kostaschuk et al., 1989). Monitoring data shows that nearbed sediment concentrations during ebb tides in the river mouth can sometimes reach 4 vol.\% (Kostaschuk et al., 1992).

Crescentic bedforms that are 1-3 $\mathrm{m}$ high and 30-50 $\mathrm{m}$ long are well developed in the tributary channels and upper part of the main channel (Hill, 2012). They are concave down-slope and migrate up-slope, as seen in Monterey Canyon (Paull et al., 2010a). A zone of sediment accumulation since 1994 extends for $1.5 \mathrm{~km}$ from the shelf break (Hill, 2012). The near-exponential thinning of this sediment package (Fig. 16) suggests that it was deposited by relatively dilute turbidity currents, perhaps resulting from dredging discharge (Hill, 2012). However, a series of head scarps at short distance further along the main channel record local slope failure, perhaps due to liquefaction of fine sand
(Fig. 16). The headscarps migrate up-slope over several months (Hill, 2012).

Levees have developed for a few hundred metres on either side of the main channel. High backscatter suggests that they may be relatively sand rich (Hill, 2012). A core from the levees comprises massive sand overlain by $\sim 2.5 \mathrm{~m}$ of mainly bioturbated mud (Hart et al., 1992). The channel floor is covered in clean sand that is difficult to core.

The high backscatter area extending for $\sim 4 \mathrm{~km}$ from the terminus of the main channel is probably sand rich (Hill, 2012), although cores are yet to be recovered. A second well defined channel extends from $\sim 200$ to 250 m (Fig. 15; Kostaschuk et al., 1992; Hart et al., 1992, 1998; Hill, 2012). Arcuate scarps at the head of this channel, and a series of scarps and blocky areas within the channel (Hart et al., 1992; their figures 6 and 8), suggest that it may in part result from local slope failure and liquefaction.

The up-slope migrating crescentic bedforms and headscarps resemble those seen in Monterey Canyon (Fig. 7). Both systems are fed mainly by sand, either by reworking of shelf sand by large waves (Monterey Canyon) or a combination of river discharge and dredging (Fraser River delta). A similar question can be asked regarding their origin. Are they due to cyclic steps in supercritical dilute flows, or mainly due to liquefaction of sandy material on the channel floor? Hart et al. (1992, 1998) argued for transport through dense (perhaps liquefied) debris flow, whilst Kostaschuk et al. (1992) inferred transport mainly via turbidity current. It is possible that liquefaction of sand results in part from shear by overlying dilute turbidity currents, or that overlying dilute flows are driven primarily by dense basal slumping of liquefied sand. The 1994 to recent flows appear to have relatively short run out distances as they mainly deposited sediment within $\sim 1.5 \mathrm{~km}$ from the shelf break (Hill, 2012). However, longer run out sediment flows must have occurred previously to cut channels and form the high backscatter lobe. It appears that the system is filled and flushed by flows of differing magnitude. Recent installation of the cabled VENUS observatory on the delta now provide exiting possibilities for monitoring of flows in action (Lintern and Hill, 2010; Ayranci et al., 2012).

\subsubsection{Itirbilung Fjord, Canada}

Syvitski and Hein (1991) provided a comprehensive overview of recent sedimentation in the Itirbilung Fjord. Currents meters at water depths of $\sim 50 \mathrm{~m}$ recorded nine turbidity currents with speeds up to $36 \mathrm{~cm} / \mathrm{s}$, each of which lasted for 1-5 h. The occurrence of the turbidity currents did not correlate with peaks of river discharge, and the turbidity currents appear to have been generated by delta front slope failure (Syvitski and Hein, 1991).

\subsection{Flows due to mine tailings discharge into the ocean}

Hay et al. (1982) and Hay (1987a,b) reported on images of turbidity currents in Rupert Inlet in British Colombia obtained using acoustic sounders with frequencies of 42.5, 107 and $200 \mathrm{kHz}$. These submarine flows resulted from periodic discharge of mine tailings into the fjord, comprising $~ 70 \%$ mud. The tailings were discharged with a volume concentration of $10 \%$, at a rate of $0.7 \mathrm{~m}^{3} \mathrm{~s}^{-1}$. Measurements made near the outfall suggest that sediment volume concentrations in resulting density flows were $<0.01 \%, 3 \mathrm{~m}$ above the bed (Hay, 1987a, 1987b).

The acoustic sounder images include those of flow within a prominent channel, and associated overbank flow in more distal unchannelised areas (Fig. 17; Hay et al., 1982). Contours of backscatter intensity suggest that the highest concentrations are close to the outfall (Hay, 1987a). The flows comprised a denser initial component that lasted $\sim 5$ min and were

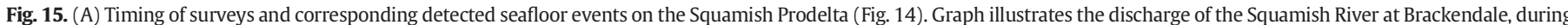

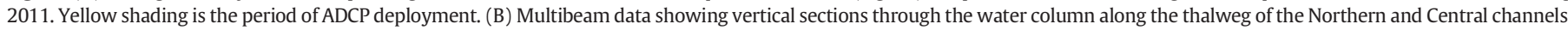

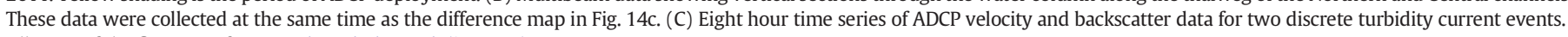
All parts of the figure are from Hughes Clarke et al. (in press). 


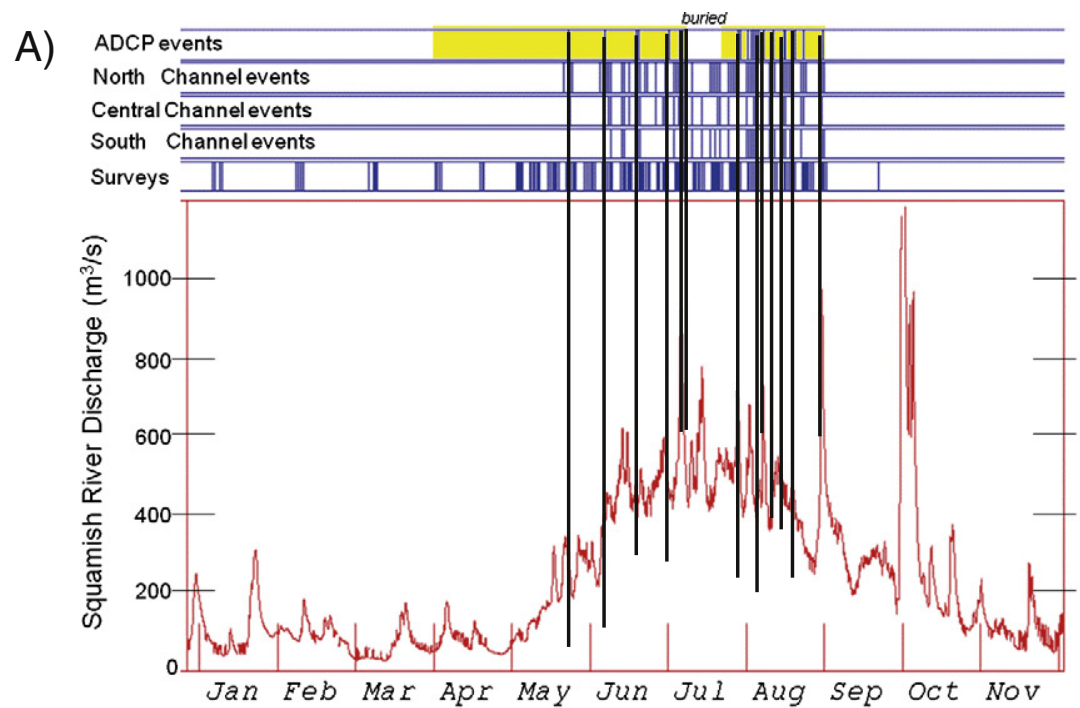

B) surface

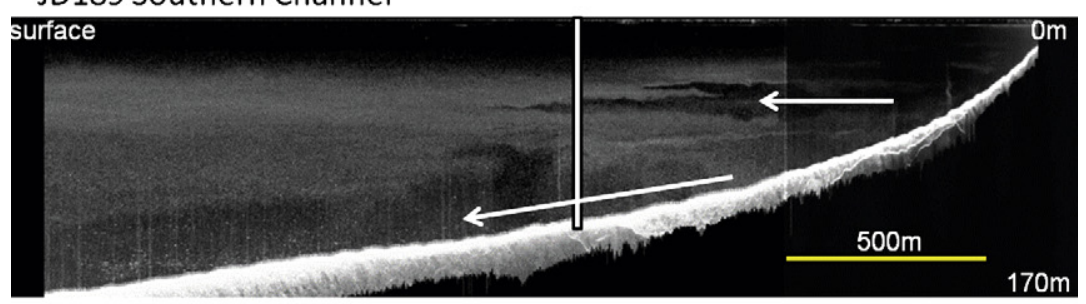

JD224 Southern Channel

Water Column logged: 1735-1805 UTC

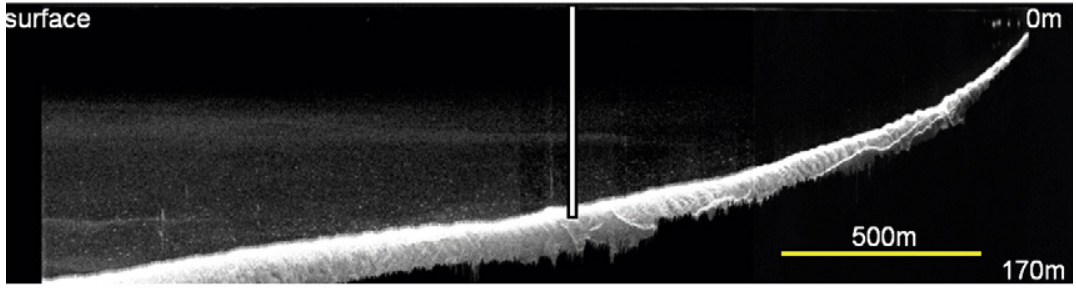

C)

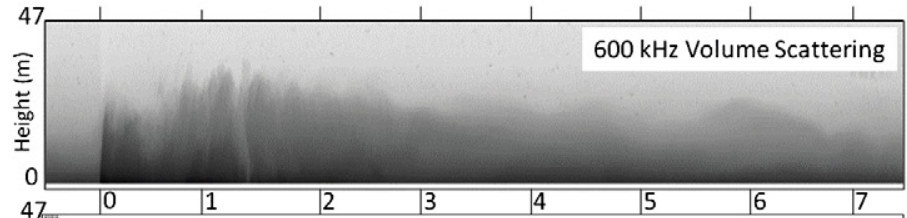

Event 8D

2011 JD206

Mon Jul 25

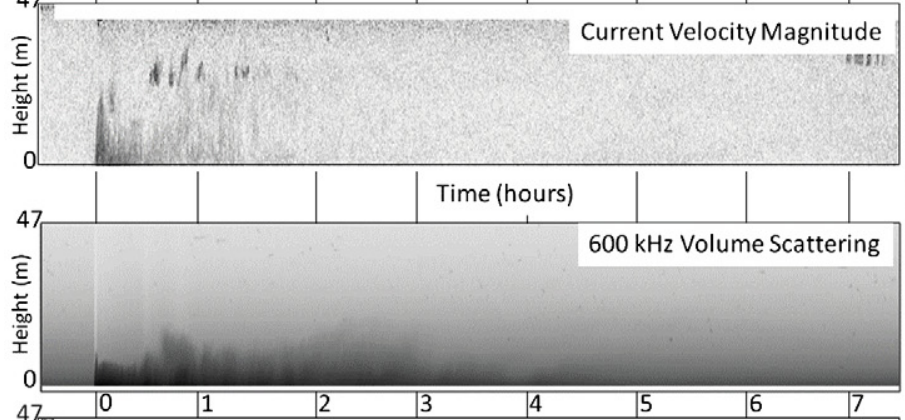

16:06:00
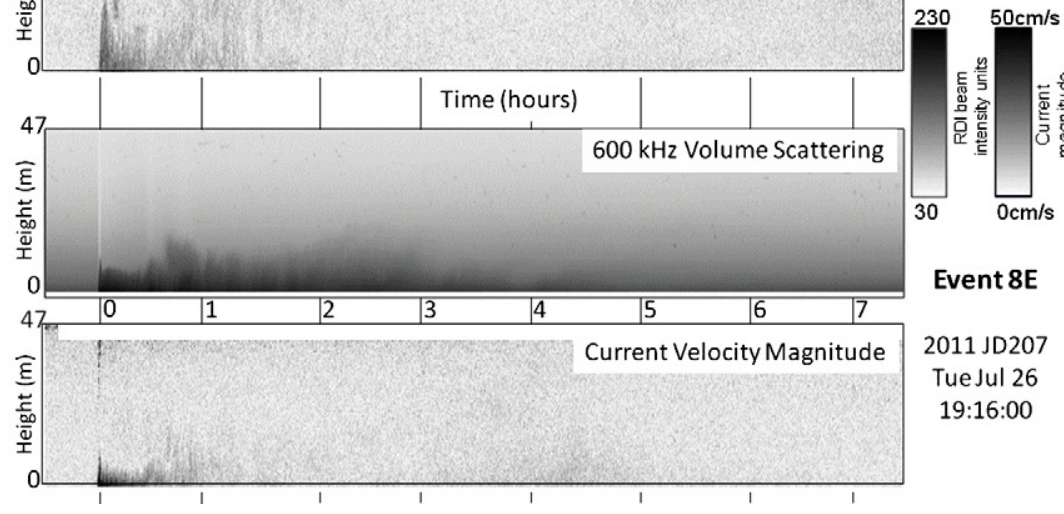


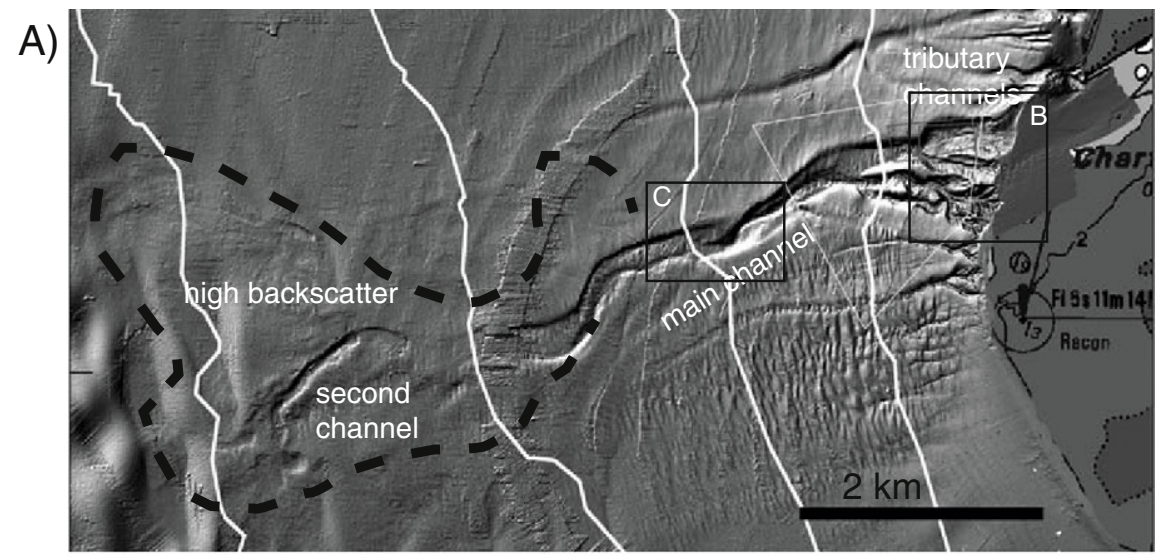

B)

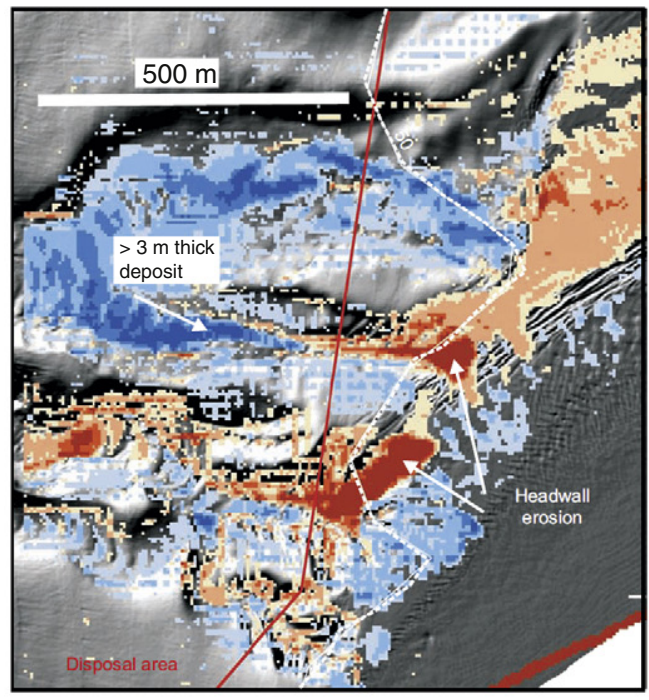

C)
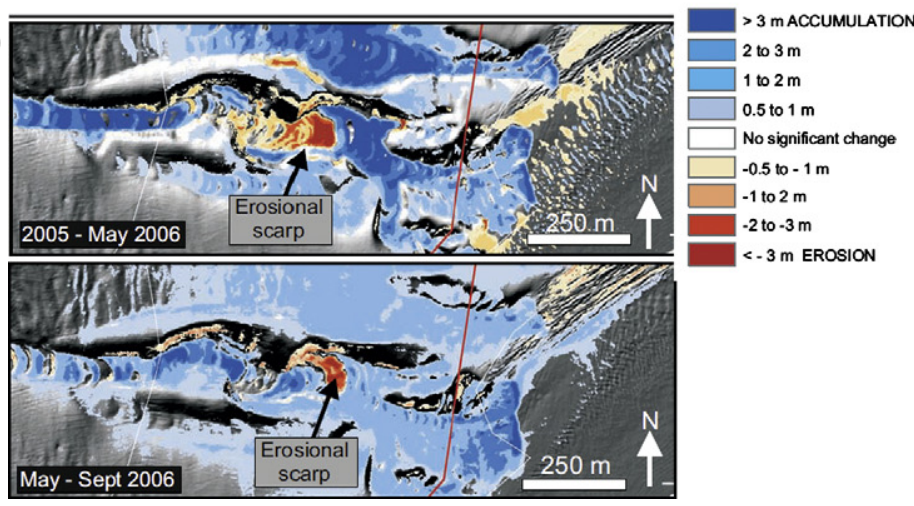

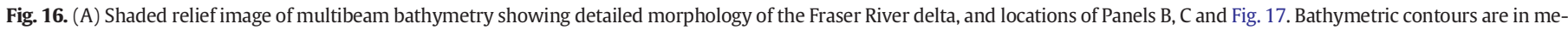

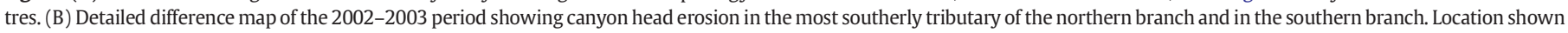
in part A. (C) Details of the southern branch channel showing changes between 2003 and September 2006. Location is shown in part A. All parts of figure from Hill (2012).

$<5 \mathrm{~m}$ thick. This was followed by a more dilute wake that persisted for 0.5 to $1.5 \mathrm{~h}$, and became gradually thicker. The flows therefore seem to represent surges, rather than flows with a prolonged and steady body (Hay et al., 1982; Hay, 1987a, 1987b).

Hay (1987b) reported that sediment concentration was $<0.01 \%$ at heights of $>4 \mathrm{~m}$ from the bed, and the maximum velocities that were measured were only $<6 \mathrm{~cm} / \mathrm{s}$. However, whether the instruments were located within the main channel is not known (Hay et al., 1982).

\subsection{Flows due to seabed trawling}

Palanques et al. (2006) and Puig et al. (2012) monitored density flows generated by ploughing of the sea floor by fishing trawlers on the flanks of the Palamos (Fonera) Canyon offshore NE Spain, which smoothed the seafloor substantially. The density flows had speeds of up to $38 \mathrm{~cm} / \mathrm{s}$ and sediment volume concentrations of up to $0.01 \%$ (Table 1; Puig et al., 2012). They contained mainly silt and clay, with 


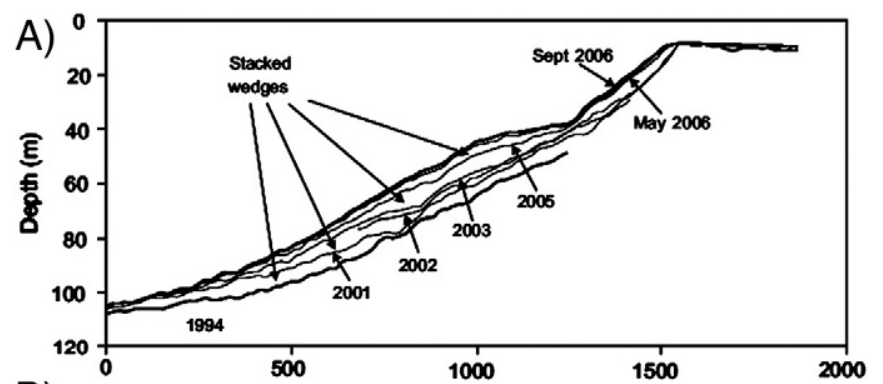

B)

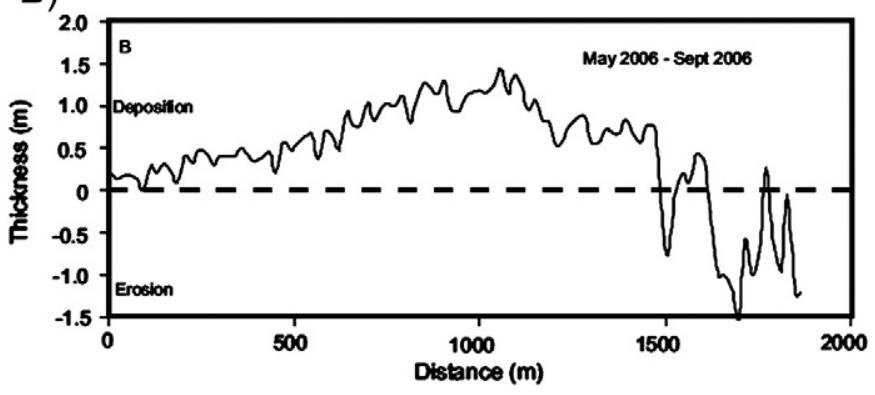

Fig. 17. (A) Down channel bathymetric profiles in the north branch of the main channel off the Fraser River delta showing wedge-shaped strata geometry. (B) Plot of deposit thickness along the same profile for the period May to September 2006. Both parts of the figure are from Hill (2012).

$0.5 \%$ to $2.5 \%$ sand found in traps located $22 \mathrm{~m}$ above the bed. These dilute flows deposited sediment at a rate of up to $\sim 0.7 \mathrm{~mm} /$ day, assuming a deposit density of $1300 \mathrm{~kg} / \mathrm{m}^{3}$. The flows travelled $\sim 5 \mathrm{~km}$ from the site of trawling to the measurement location at $1200 \mathrm{~m}$ water depth, but not all days of trawling generated flows that ran out this far. Trawler induced flows were not observed $15 \mathrm{~km}$ further downslope at a water depth of $1700 \mathrm{~m}$, and these flows appear to be relatively short run out events that deposited fine sediment locally along the canyon floor. These flows do not appear to have ignited and accelerated.

\section{Monitoring data from lakes and reservoirs}

Sediment-laden flood discharge (especially from glacially-fed rivers) can produce turbidity currents in lakes or reservoirs whose occurrence is relatively frequent and more predictable (Forel, 1885). These density flows are typically dilute $(<0.01$ vol.\% sediment) and slow moving $(<50 \mathrm{~cm} / \mathrm{s})$, such that monitoring equipment is not damaged by the flows (Table 2). Shallower water depths and the often smaller scale of these lacustrine or reservoir flows also makes them easier to monitor than larger deep-water submarine systems. This has allowed a number of relatively detailed studies of turbidity currents in lakes and reservoirs (Table 2).

The formation of density flows within freshwater, as opposed to seawater, may lead to differences in flow behaviour. The sediment concentration needed for sediment-laden flood water to plunge is reduced in freshwater bodies, as compared to sea water. This allows the formation of plunging density flows in freshwater with low sediment concentrations. Lakes and reservoirs are often seasonally strongly density stratified (Talling, 1966), and incoming density flows commonly form very dilute surface flows or interflows along thermoclines, as well as bottom hugging density flows (Pharo and Carmack, 1979; Weirich, 1984, 1986a,b; Chikita, 1989, 1990; De Cesare et al., 2001, 2006; Umeda et al., 2006; Fernandez and Imberger, 2008; Marti et al., 2011). The dilute nature of many density flows in lakes and reservoirs may also make them prone to lifting off with reversing buoyancy, once they have started to deposit sediment (Sparks et al., 1993; Hurzeler et al., 1996).
Density flows in lakes and reservoirs typically start on delta-fronts where the gradients commonly vary from 0.2 to $12^{\circ}$ (Table 1 ). Deeply cut canyons are generally absent in lakes and reservoirs, although well developed channels do occur in some places (e.g. Lake Geneva and Walensee; Forel, 1885, 1895; Lambert and Hsu, 1979; Lambert and Giovanoli, 1988; Girardclos et al., 2012), presumably due to occurrence of more powerful flows (Lambert and Giovanoli, 1988). Channels are notably absent elsewhere (Gilbert and Crookshanks, 2009). This contrasts with marine settings where channel and canyon systems are more common.

\subsection{Density flows generated directly by river flood discharge}

The relatively slow and dilute flows in lakes and reservoirs that are generated by river floodwater have consistent features in differing locations, and are described first. A single example of a faster $(\sim 3 \mathrm{~m} / \mathrm{s})$ lacustrine density flow that was not associated directly with a river flood is then described (Lambert and Giovanoli, 1988), followed by studies of density flows in Lake Superior generated by mine tailings discharge (Table 2; Normark and Dickson, 1976a,b; Normark, 1989).

\subsubsection{Flood input conditions}

In lakes and reservoirs, river flood discharge is often sustained for several days, and can be sustained for weeks (Crookshanks and Gilbert, 2008), generating prolonged turbidity currents (Table 2). The volume concentrations of suspended sediment in river flood water are typically between 0.01 (Umeda et al., 2006) and 0.3 vol.\% (De Cesare et al., 2006; Table 2). Flood discharge also includes a component of bedload, although it is unclear whether this coarser bedload material is always rapidly deposited, or whether it can be incorporated into density flows.

\subsubsection{Interflows and surface flows}

Seasonal stratification often leads to generation of one (or sometimes multiple) interflow, as density flow(s) propagates along a density interface within the water body (Pharo and Carmack, 1979; Weirich, 1984, 1986a,b; Chikita, 1989,1990; De Cesare et al., 2006; Umeda et al., 2006; Fernandez and Imberger, 2008; Marti et al., 2011). Interflows are particularly dilute, with measured sediment concentrations of $<0.005$ vol.\%, and typically carry only fine sediment. Surface plumes of flood water with even lower sediment concentrations are also often associated with flood discharge events. Both interflows and surface flows may contribute towards deposition of thin (mm-scale) and finegrained laminations on the lake or reservoir floor.

\subsubsection{Sediment concentration in basin-floor density flows}

Sediment concentration in density flows within lakes and reservoirs has been measured in numerous locations (Table 2), which contrast to the almost complete lack of sediment concentration measurements in submarine density flows (Table 1 ). Density flows along the floor or lakes and reservoirs are typically dilute with maximum measured volume concentrations of $0.07 \%$ to $0.001 \%$ for suspended sediment (Table 2), with sediment concentrations increasing progressively towards the bed (e.g. Chikita, 1990; Best et al., 2005; Umeda et al., 2006; Crookshanks and Gilbert, 2008).

\subsubsection{Density flow velocities}

Maximum flow velocities are typically between 5 and $60 \mathrm{~cm} / \mathrm{s}$, with some flows reaching speeds of $1.2 \mathrm{~m} / \mathrm{s}$ (Table 2; Lambert, 1982). The fastest flows $(>1 \mathrm{~m} / \mathrm{s})$ are sometimes associated with steeper gradients $\left(2^{\circ}\right.$ to $\left.12^{\circ}\right)$ in locations closer to $(<100 \mathrm{~m})$ shore (Weirich, 1984 , $1986 a, b)$. The maximum velocity tends to occur within a few metres of bed (Chikita, 1990; Best et al., 2005; Wei et al., 2013).

In some cases, where detailed time series are available, the velocity show repeated pulses (Lambert and Hsu, 1979; Lambert, 1982; Best et al., 2005). Pulsing has been attributed to shifting of the position where river flood water plunges (Best et al., 2005). 
A)

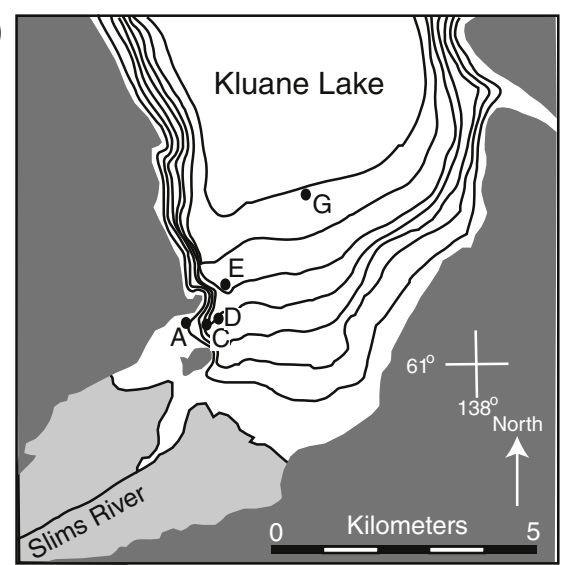

C)

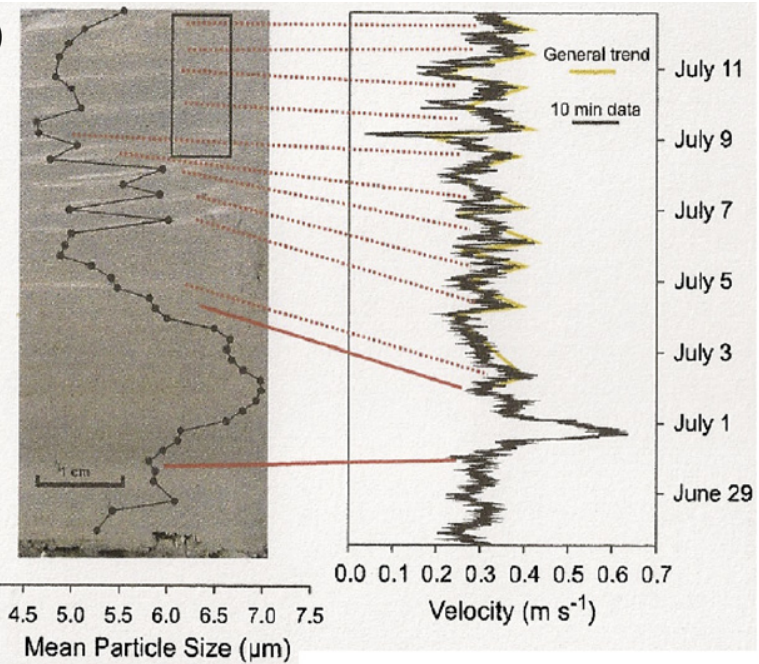

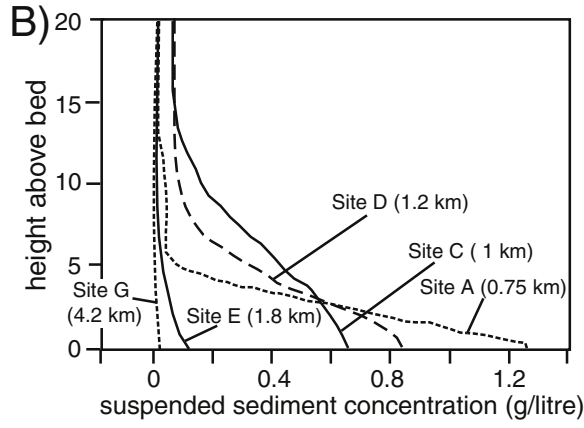

\begin{tabular}{cccccc}
\hline & 1 & 1 & 1 & 1 & 1 \\
0 & $0.1 \%$ & $0.2 \%$ & $0.3 \%$ & $0.4 \%$ & $0.5 \%$
\end{tabular}

suspended sediment concentration (percentage volume)

D)

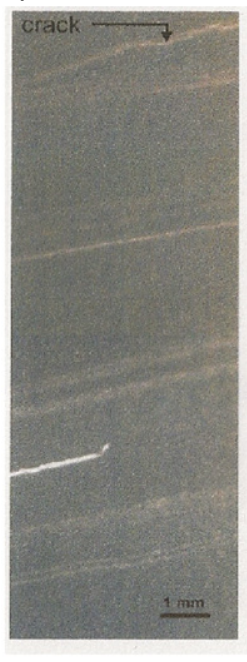

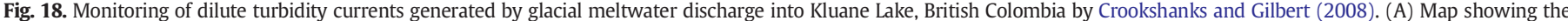

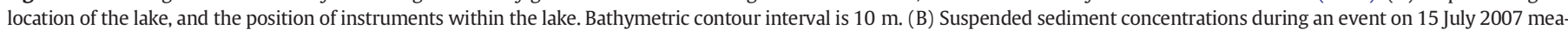

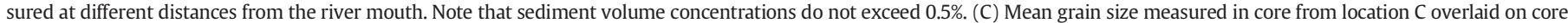

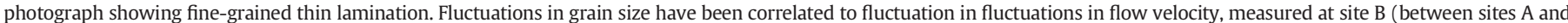
C). (D) More detailed photograph from thin section of fine-grained and thinly laminated deposits in the core from location C. All figures are from Crookshanks and Gilbert (2008).

\subsubsection{Flow thicknesses}

Measured flow thicknesses vary from 3 to $16 \mathrm{~m}$ (Table 2), such that density flows in lakes and reservoirs are thinner than some submarine density flows that can be tens to $>100 \mathrm{~m}$ thick (Table 1). This at least partly reflects the relatively shallow water depths in most lakes.

\subsubsection{Run out length}

Flows often run out for several kilometres, and in some cases travel for tens of kilometres whilst maintaining speeds of up to $25 \mathrm{~cm} / \mathrm{s}$ (Gould, 1960; Lake Meade; Table 2).

\subsubsection{Flow duration and frequency}

Prolonged river floodwater discharge leads to prolonged density flows, which often last for several days (Table 2). Crookshanks and Gilbert (2008) show that flows can sometimes be continuous over several weeks, with diurnal fluctuation mimicking change in meltwater river discharge. In some locations, tens of flow events have occurred during a single year. For instance, Lambert and Giovanoli
(1988) showed that 31 events occurred in Lake Geneva during a period of 81 days.

\subsubsection{Size of suspended sediment}

Direct sampling and coring of basin floor deposits in lakes and reservoirs suggest that flood triggered density flows mainly (>60 to 99\%) comprise silt and clay (Umeda et al., 2006; Chikita and Okumura, 1987, 1990; Chikita, 1989, 1990; Crookshanks and Gilbert, 2008). Flows that are faster than $\sim 20 \mathrm{~cm} / \mathrm{s}$ would be capable of transporting finer sand as bedload, whilst flows that travel at $>\sim 50 \mathrm{~cm} / \mathrm{s}$ can suspend sand above the bed (Komar, 1985). This supports the view that thin and fine grained deposits characterise the weak density flows associated with hyperpycnal flood discharges.

\subsubsection{Deposit character}

Few studies have described in detail the deposits known to result from specific monitored flows (Fig. 18; Crookshanks and Gilbert, 2008 is a notable exception), although coring has often recovered deposits from recent flow events, presumably of a similar general type (Table 2).

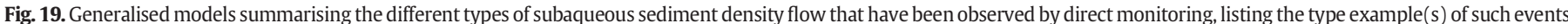

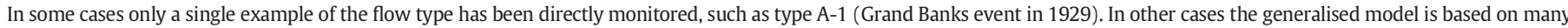

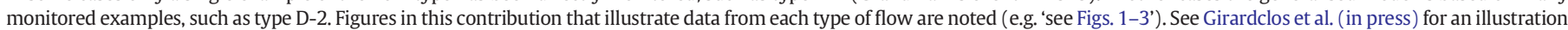
of subaqueous channels on a lacustrine delta front (type D-1). See Liu et al. (2012) and Khripounoff et al. (2009, 2012) for figures illustrating flow type C-2. 


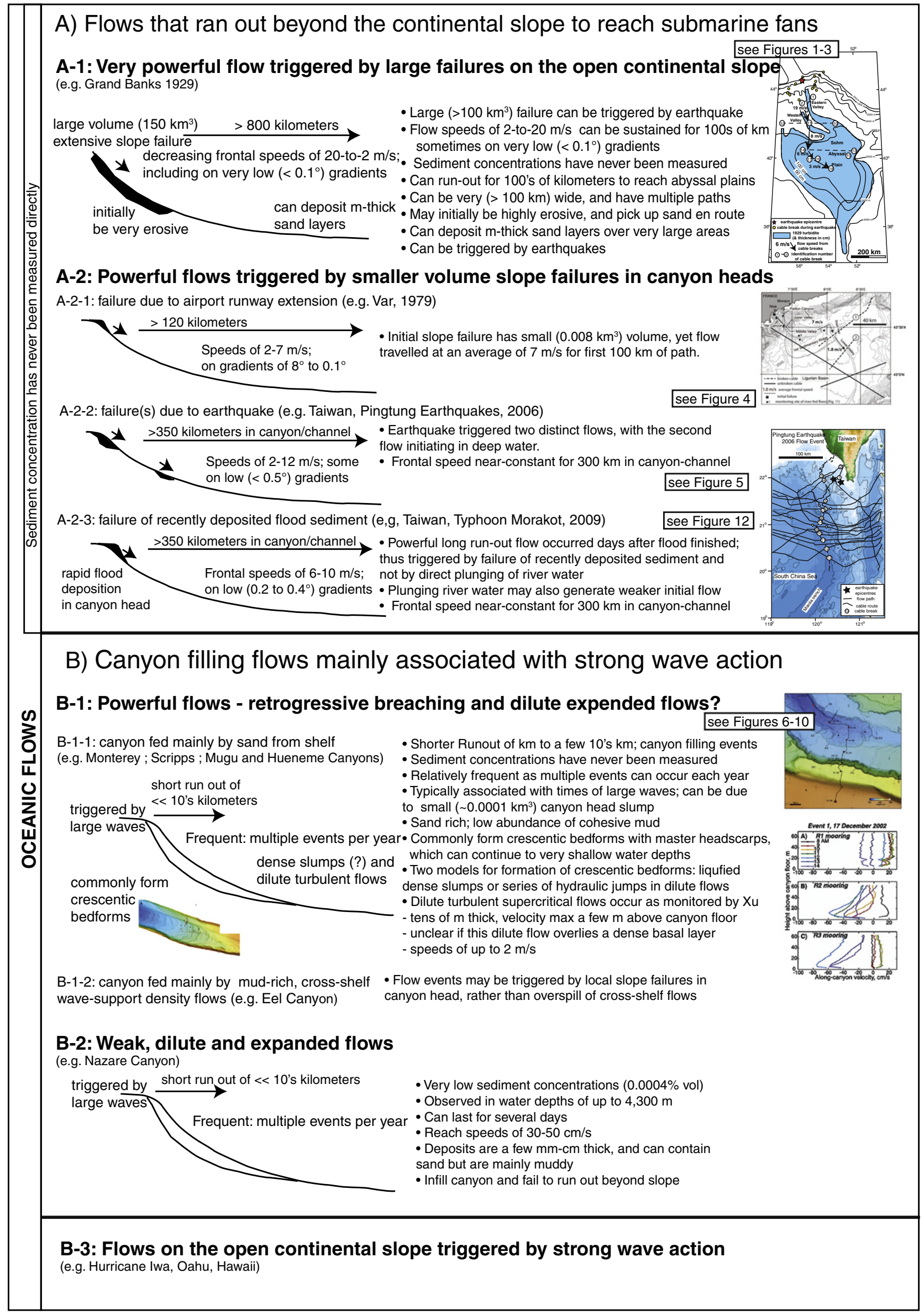




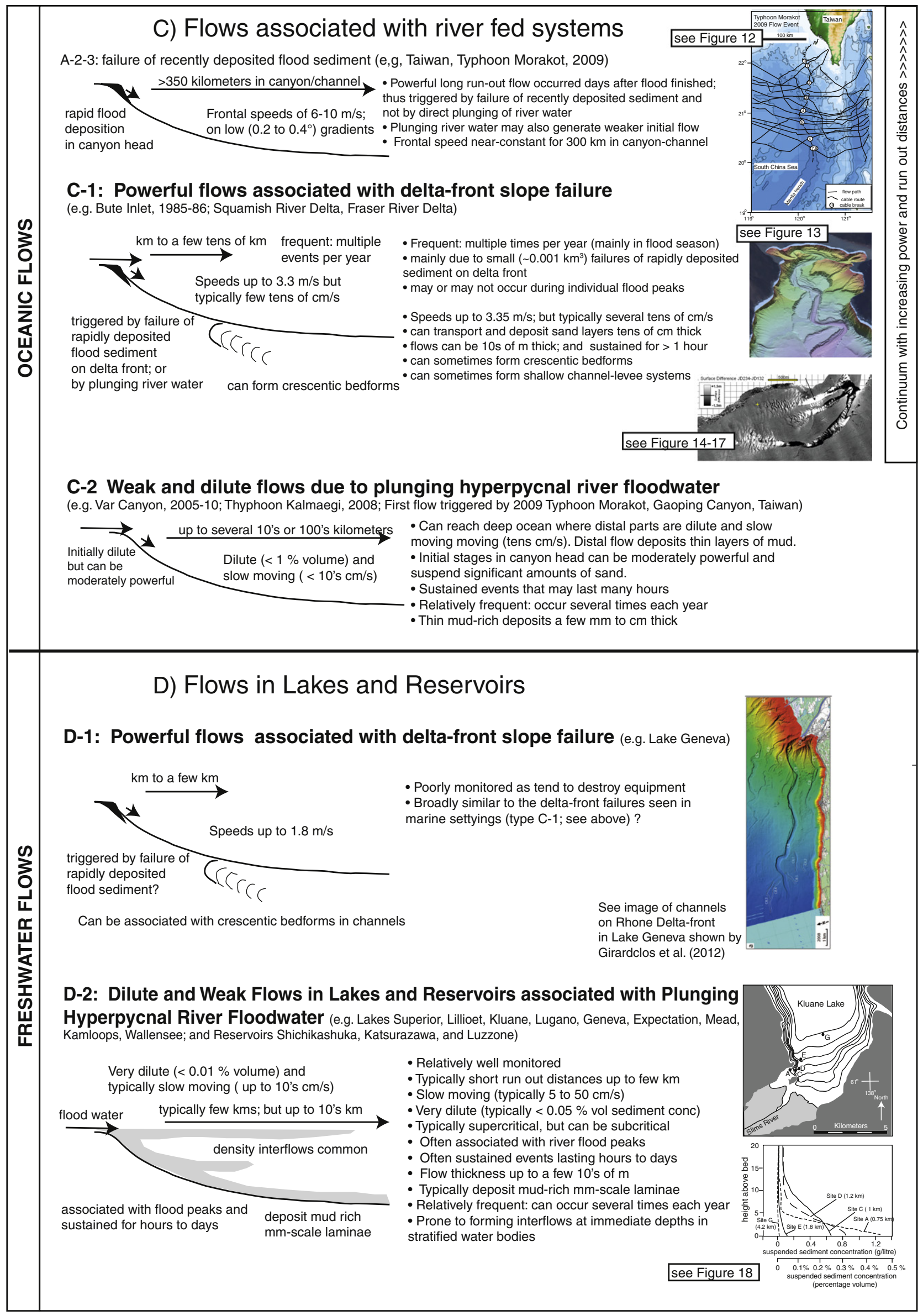


Deposits from basin floors typically comprised thin layers that are $\mathrm{mm}$ to $<2 \mathrm{~cm}$ thick, which comprise mainly silt and clay (Table 2; Lambert and Hsu, 1979; Umeda et al., 2006; Gilbert et al., 2006; Crookshanks and Gilbert, 2008). However, sand layers have been recovered from steeper delta fronts that can be up to a few $\mathrm{cm}$ thick (Best et al., 2005; Gilbert et al., 2006).

\subsection{Fast flows in lakes - not generated directly by flood discharge}

Lambert and Giovanoli (1988) described a powerful flow in a channel that extends from the Rhone delta-front in Lake Geneva (Forel, 1885; Girardclos et al., 2012), which badly damaged their monitoring equipment. They were able to estimate a flow velocity of $\sim 3 \mathrm{~m} / \mathrm{s}$ from the time at which two moorings broke. A density flow with a peak velocity of $0.9 \mathrm{~m} / \mathrm{s}$ was generated by a large river flood that occurred $\sim 12$ h before the moorings broke loose. However, at the time the moorings broke the river flood had subsided.

Lambert and Giovanoli (1988) inferred that this flow was triggered by delta-front slope failure, which may have generated faster flow due to higher flow density and/or greater thickness and sediment flux. This event was significantly faster than the density flows formed directly by plunging flood discharge at this location. The occurrence of powerful flows, commonly triggered by slope failure, may be attributed to the development of channel systems, which are prominent on the Rhone delta-front (Forel, 1885; Girardclos et al., 2012) but absent in many lakes.

\subsection{Density flows generated by mine tailings discharge in lakes}

Normark and Dickson (1976a,b) and Normark (1989) described density flows in Lake Superior that were generated by sustained discharge of mine tailings. The tailings were discharged at volume concentrations of $\sim 0.01 \%$ into a well developed channel. Current meters located 3 to $5 \mathrm{~m}$ above the bed recorded velocities of 3 to $16 \mathrm{~cm} / \mathrm{s}$. A single measurement of $0.0018 \%$ sediment volume concentration was made $5 \mathrm{~m}$ above the bed. The flows were 3 to $16 \mathrm{~m}$ thick, lasted for up to 2 weeks, ran out for at least $3 \mathrm{~km}$, and were most likely supercritical and fully turbulent (Normark and Dickson, 1976a,b; Normark, 1989). An innovative set of magnets were used to show how sediment flux (of the magnetic fraction of tailings) increased above the bed (Normark, 1989).

\section{Non-particulate density currents}

Considerable advances have been made in recent years to understand density flows driven primarily by changes in water density rather than by the excess density of their sediment load. This includes work examining how dense water masses generated on shallow shelves can cascade offshore (Canals et al., 2006; Puig et al., 2008; Palanques et al., 2009; Pasqual et al., 2010), and ongoing projects monitoring the channelized outflow from the Black Sea (Parsons et al., 2010).

Dense water cascades can last for days to weeks and have reached speeds (measured $5 \mathrm{~m}$ above the sea floor) of 0.2 to $1 \mathrm{~m} / \mathrm{s}$ that are sufficient to transport sand. The suspended sediment concentrations measured in these events are typically very low, with values of 0.002 to $0.005 \mathrm{~g} / \mathrm{l}$ (equivalent to volume sediment concentrations of $\sim 0.001 \%$ ) recorded several metres above the sea floor. Average sedimentation rates measured by sediment traps over periods of days are also relatively slow, reaching values of 10 to $50 \mathrm{~g} / \mathrm{m}^{2} / \mathrm{s}$ (equivalent to vertical accumulation rates of $\sim 0.01$ to $0.001 \mathrm{~mm} / \mathrm{m}^{2} / \mathrm{s}$ ). Very substantial volumes of water can be transported into the deep ocean during prolonged dense water cascading events, such as the $750 \mathrm{~km}^{3}$ of water that was estimated to have been transported during a 40 day event in the Cap de Creus Canyon to the Gulf of Lions (Canals et al., 2006). However, the low sediment concentrations in these events reduce the volume of sediment that they transport. For instance, whilst $750 \mathrm{~km}^{3}$ of water passed through the canyon, only $0.005 \mathrm{~km}^{3}$ of sediment was transported in the 40 day event described by Canals et al. (2006, 2009). These dilute sediment flow may produce thin deposits in the deep ocean, erode furrows in canyons, and export significant amounts of particulate and dissolved organic carbon (Canals et al., 2006; Puig et al., 2008; Palanques et al., 2009; Pasqual et al., 2010), but it is less likely that they can lead to extensive deposition of thick and coarse sand layers.

The evolution of these predominantly thermohaline density flows differs significantly from density flows driven by suspensions of sediment, as processes of sediment settling will have a much weaker influence on flow density and hence flow evolution. These dilute flows may differ significantly from flows with higher sediment concentrations. Even small amounts of sediment (especially cohesive mud) can damp turbulence and modify the sediment carrying capacity, structure and evolution of the flow.

\section{Discussion}

We start by characterising and classifying the main types of sediment density flow that have been observed in oceans, lakes and reservoirs. This is followed by a summary of the types of observation that are available, and a quantitative analysis of the flow parameters that have been measured for submarine flows. In particular, we discuss whether there is evidence for flow ignition or dissipation. We then address the question of whether these submarine flows are the most poorly monitored major sediment transport process on Earth, by a comparison to the type of monitoring information available for other major sediment transport processes. We conclude with suggestions for future strategies for improved monitoring of submarine flows.

\subsection{Types of monitored submarine sediment density flow}

Direct monitoring datasets illustrate the highly variable character of submarine sediment density flows. This section outlines a series of simplified generalised models for the different types of submarine flow that have been monitored, capturing this variability (Fig. 19).

\subsubsection{Long run-out, powerful flows that reach submarine fans}

There are very few direct observations from flows that extend well beyond submarine canyons or fan-valleys that dissect the continental shelf, and deposit sediment across submarine fans (Fig. 19A; Type A). However, it is these flows that transport the largest volumes of sediment, and form the submarine fan sequences that comprise most of the rock record. Their sediment concentration has never been measured directly, their speed has only been documented in five locations (offshore from the Grand Banks, Nice, Taiwan, Zaire and Algeria), and only the deposits of the 1929 Grand Banks event have been sampled in any detail.

7.1.1.1. Flows triggered by very large-scale failures on the open continental slope. The 1929 Grand Banks event shows how particularly powerful flows can be generated by large $\left(>100 \mathrm{~km}^{3}\right)$ landslides on the open continental slope. Frontal flow speeds reached $19 \mathrm{~m} / \mathrm{s}$ on gradients $>\sim 1^{\circ}$, where flow was largely confined within fan valleys on the continental slope and was up to several hundred metres thick. Speeds of $\sim 2$ to $8 \mathrm{~m} / \mathrm{s}$ were sustained for hundreds of kilometres across gradients of just $\sim 0.1^{\circ}$ to $0.3^{\circ}$, even though flow expanded to be several hundred kilometres wide (Fig. 1). This fast moving flow was highly erosive with at least $\sim 80 \%$ of the sand within the final deposit reworked from the fan valley. The 1929 Grand Banks event was triggered by a large magnitude earthquake, which caused slope failure that probably occurred simultaneously in locations spread over a wide area of sea floor. Whether other processes can trigger such large-scale slope failure is unclear. 
7.1.1.2. Flows triggered by much smaller-scale failures within canyons. Powerful, long run-out flows can also be triggered by much smaller volume $\left(<0.01 \mathrm{~km}^{3}\right)$ slope failures within canyon heads, such as during the 1979 event offshore Nice, whose initial volume is five orders of magnitude smaller than that of the 1929 Grand Banks failure (Fig. 19; Type A2 ). Even though the initial failure can be relatively small, flow speeds of 3.7 to $20 \mathrm{~m} / \mathrm{s}$ can be sustained for hundreds of kilometres, perhaps in part due to confinement within a canyon-channel system. Canyon head slope failure can be triggered by the addition of sediment (Var in 1979), a large earthquake that can also trigger additional failures further down the canyon (Gaoping Canyon, Taiwan in 2006), or by recent rapid deposition of sediment during a major flood (Gaoping Canyon, Taiwan in 2009). These fast moving flows are also most likely erosive in their initial stages, and the 1979 event offshore Nice appears to have entrained large amounts of sand.

\subsubsection{Canyon-confined flows mainly associated with strong wave action}

These shorter run-out events tend to be restricted to canyons, and primarily act to in-fill the canyon with sediment (Type B; Fig. 19). The canyons can be primarily fed by shelf sediment reworked by waves (Monterey, Mugu, Hueneme, Scripps and Nazare Canyons), or by wave-supported density flows that rework mud-rich riverine flood deposits across the shelf (Eel Canyon).

7.1.2.1. Flows in canyons fed mainly by sand from the shelf. Relatively powerful flows that in some cases damaged instruments or had peak velocities in excess of $1 \mathrm{~m} / \mathrm{s}$ were observed in the Monterey, Mugu, Hueneme and Scripps Canyons along the Californian Margin, which are mainly fed by sand from the shelf (Type B-1-1; Fig. 19). At least in the case of the Monterey Canyon (Paull et al., 2010b), Mugu-Hueneme canyons (Gorsline, 1996) and Scripps-La Jolla Canyon (Piper, 1970), most or all events did not reach the lower canyon or fan valley and therefore have run out distances of less than $50 \mathrm{~km}$. These relatively frequent (often subannual) events are commonly associated with large wave heights.

Two types of sediment transport events may occur within these confined coarse sediment filled canyons. Crescentic bedforms may be generated by up-slope migrating breaches and cyclic hydraulic jumps, associated with the presence of loosely packed sand on the canyon floor that becomes partially liquefied when disturbed (see Sections 4.3.1 and 4.3.2). Cyclic wave loading is one mechanism to disturb these deposits. Sand within these relatively thin and dense liquefied layers may not travel for long distances during each individual event, but the flows can entrain and bury heavy objects. Hydraulic jumps within the dense layer of moving sand may contribute to bedform development, as seen during dredging. Alternatively, or in addition to the breaching, the bedforms may experience internal failure and rotational slumping. How movements of these bedforms initiate, but their steep $\left(15^{\circ}\right)$ down-canyon faces may favour continued motion. This breaching process explains the presence of master headscarps that form the upper boundary of individual trains of crescentic bedforms (Paull et al., 2011, 2012), evidence from ROV-coring that sand is only transported a few metres above canyon floors (Paull et al., 2010a), and that crescentic bedforms extend to the very top of the canyon (Paull et al., 2010a). It is also consistent with video footage of local liquefaction of canyon-floor sand when loaded by ROVs (Paull et al., 2012), and reports that divers encountered very loosely packed sand into which their hand could penetrate (Dill, 1964; Shepard and Dill, 1966). Shepard and Dill (1966) also concluded that sand was episodically moved in slump or thin and dense flows in Scripps and La Jolla Canyons.

Some canyon-confined events also clearly involve relatively dilute ( $\ll 5$ vol.\%) sediment suspensions, as they can be penetrated by ADCPs. These dilute suspensions are a few tens of metres thick, travel at maximum speeds of up to $2.8 \mathrm{~m} / \mathrm{s}$, and are expanded and supercritical (Xu et al., 2004, 2010; Xu, 2010). These maximum speeds are achieved a few metres above the canyon floor, and are sufficient to transport sand. It is possible that a single event may comprise both a basal dense flow, and an overlying dilute and fully turbulent sediment suspension. Cyclic steps formed by repeated hydraulic jumps in supercritical dilute flow may also play a role in the formation of the crescentic bedforms (Cartigny et al., 2010). Further work is needed to resolve the origin and dynamics of the crescentic bedforms, and the potential linkages between dense and dilute flow types.

7.1.2.2. Weak and very dilute canyon-confined flows. Detailed observations in Nazaré Canyon have shown how expanded, very dilute $(<0.001$ vol.\%), and slow moving $(<50 \mathrm{~cm} / \mathrm{s})$ flows can also coincide with periods of strong wave action. These flows could transport sand, but were generally finer grained, and they caused rapid accumulation of mud-rich sediment in the upper canyon. These flows did not exit the canyon.

7.1.2.3. Relatively infrequent canyon-flushing events. Much rarer longrun-out ('canyon flushing') flows are inferred from deep-water cores located at $\sim 3300 \mathrm{~m}$ in the Monterey Fan-channel, and in basin plains beyond the mouths of the Nazare and Scripps Canyons (Piper, 1970; Arzola et al., 2008; Paull et al., 2010b). It is assumed that sand is carried to these deeper water locations by isolated large events rather than a collage of smaller local events, and this is supported by the nature of the deepwater deposits (Piper, 1970). The volumes of sand deposited by these infrequent canyon-flushing flows are orders of magnitude greater than the amounts of sand involved in single monitored events in the canyons (Piper, 1970). The role of the smaller more frequent events in the upper parts of canyons may be to supply sufficient sediment to allow an occasional flow to "ignite" by eroding large amounts of sand from the canyon. It is not yet clear whether the infrequent canyon-flushing events are initiated in the same way as smaller canyon-filling events. If they are, then it is unclear why only a small number of the smaller events ignite into much bigger canyon-flushing flows. Alternatively, the canyon flushing flows could originate in a different fashion, for example through large-scale canyon side failures triggered by earthquakes or storms.

7.1.2.4. Flows on the open continental slope associated with strong wave action. Monitoring data shows that powerful flows can also be generated on the open continental slope during periods with large wave heights, such as offshore Oahu in Hawaii during Hurricane Iwa in 1982. However, the origin of such flows is poorly constrained.

\subsubsection{Flows in systems fed by rivers}

We now summarise the types of submarine density flow that have been observed in systems that are mainly supplied with sediment by river floods (Type C; Fig. 19). These observations come from delta fronts, or canyon-channel systems that extend to the vicinity of river mouths.

7.1.3.1. Very powerful, long run-out flows that reached the deep ocean. The flow that occurred in Gaoping Canyon in 2009 shows that a river-fed system can generate powerful density flows that run-out for long distances and reach the deep ocean (Fig. 11; see also Section 7.1.1.2). This event was associated with a large flood produced by near-record rainfall during Typhoon Morakot. Cable breaks occurred several days after peak flood discharge, showing that this flow was triggered by failure of rapidly deposited sediment in the upper canyon, rather than by direct plunging of hyperpycnal river water (Fig. 11; Carter et al., 2012). Observations from $4000 \mathrm{~m}$ water depth in the Zaire submarine channel confirm that powerful flows can reach the deep ocean in a river fed system (Fig. 10). The flow that was observed in 2001 was not associated with a major river flood (Khripounoff et al., 2003), and was therefore most likely generated by slope failure in the upper canyon. The trigger for subsequent flows in 2004 and 2009-10 is not known. 
7.1.3.2. Flows on delta-fronts - mainly associated with delta-front slope failure. Flows primarily occur during the flood season when river discharge is relatively high but they often do not coincide with individual peaks in river flood discharge (Figs. $13 \mathrm{c}$ and 15a). This suggests that the majority of these flows were associated with failure of rapid deposition of flood sediment, and were not triggered directly by plunging hyperpycnal river floodwater (Bornhold et al., 1994; Ren et al., 1996). However, flows that coincide with individual floods could be associated with plunging hyperpycnal river discharge. Detailed repeated mapping shows that relatively small scale failures $\left(<\sim 0.001 \mathrm{~km}^{3}\right)$ are common on these delta fronts, and the timing of these failures often coincides with the maximum flow velocities ( 1.5 to $3.5 \mathrm{~m} / \mathrm{s}$ ) recorded by current meters (Hughes Clarke et al., 2012; Hill, 2012). These flows can be sufficiently powerful to deposit beds of muddy sand that are up to $\sim 18 \mathrm{~cm}$ thick (Prior et al., 1987), and to cut submarine channel systems that are tens of metres deep (Conway et al., 2012; Hill, 2012; Hughes Clarke et al., 2012). These channel systems can extend for a few kilometres (Squamish Delta; Hughes Clarke et al., 2012), or several tens of kilometres (Bute and Knight Inlets; Conway et al., 2012), and there is a continuum of increasing channel development presumably reflecting increasing flow power and/or frequency (Fig. 19; type C). The factors determine the exact timing of the failures remains unclear but probably involves rapid sediment deposition on these steep delta fronts. Hughes Clarke et al. (2012) observed that the largest failures coincide with unusually low tides on the Squamish Delta, when the river discharge became more narrowly focused as water levels dropped.

Flows initiated on delta fronts can produce well-developed crescentic bedforms that migrate upslope (Hughes Clarke et al., 2012; Hill, 2012), with many tens of episodes of motion during a flood season (Hughes Clarke et al., 2012). These crescentic bedforms closely resemble those seen on the floor of Monterey and Mugu Canyons, where we previously inferred that they are most likely generated by retrogressive breaching associated with cyclic hydraulic jumps, when loosely packed sand is disturbed by cyclic wave loading. Locations such as the Squamish Delta are not affected by large waves, suggesting that other processes initiate crescentic bedform migration. Similar crescentic bedforms are seen in channels on the Rhone delta-front in Lake Geneva (Girardclos et al., 2012) showing that their formation is widespread.

7.1.3.3. Dilute flows generated by plunging river flood water in the ocean. Observations offshore from the Var River in 2005-2010 (Khripounoff et al., 2009, 2012) and the Gaoping Canyon in 2008 (Liu et al., 2012) show that plunging of river flood water can generate sustained and relatively dilute sediment density flows in submarine settings (Figs. 10 and 11). The 2008 density flow in the Gaoping Canyon was initially powerful within the canyon head. Flow speeds of up to $1.6 \mathrm{~m} / \mathrm{s}$ were measured $56 \mathrm{~m}$ above the bed, and this event transported significant amounts of sand at least $42 \mathrm{~m}$ above the bed (Liu et al., 2012). However, both the 2005-2010 Var and 2008 Gaoping Canyon events were slowly moving as they passed into deep water. The 2008 event in the Gaoping Canyon failed to break cables located $>70 \mathrm{~km}$ offshore (Figs. 5 and 11). One of the six events described by Khripounoff et al. (2009) in the Var system ran out for many tens of kilometres to reach water depths of $\sim 2350 \mathrm{~m}$ (station B; Fig. 4). However, this event was recorded only by a subtle change in turbidity without any change in velocity data. The remaining five flood-triggered five events were restricted to shallower water depths (Fig. 12).

The 2005-2008 flows offshore from the Var only carried fine sediment, and deposited sediment relatively slowly at $\ll 0.5 \mathrm{~mm} /$ day (Khripounoff et al., 2009, 2012). These prolonged but dilute flows would only have deposited thin (mm-scale) mud-rich layers. The 2008 event in the Gaoping Canyon transported sand within the proximal canyon head (Liu et al., 2012), but it is not known whether it carried sand much further offshore. Understanding of these events is confounded by rapid sediment deposition on the steep canyon sides that can trigger slumping. Thus, whether submarine flows associated with plunging of river flood water can erode sufficient sand passing through the steep upper part of a canyon to eventually deposit thick (tens of centimetres to several metres) sand layers that characterise many basin plain, lobe and channel axis outcrops in the rock record remains unclear. Neither is it known whether hyperconcentrated flows from rivers (Prior and Bornhold, 1989; Mulder et al., 2009) can evolve to create such deposits.

\subsubsection{Flows in lakes and reservoirs}

Observations from lakes and reservoirs have almost exclusively recorded dilute and slow moving density flows that have limited run out distances, which are generated directly by plunging of hyperpycnal river flood water (Table 2). These locations typically lack well developed channel systems. However, monitoring of the Rhone Delta in Lake Geneva has also documented more powerful events, which are associated with well developed channels.

7.1.4.1. Dilute, slow flows generated by plunging flood water. These flows have sediment volume concentrations of less than $0.07 \%$ to $0.001 \%$, and their maximum speeds are typically few tens of $\mathrm{cm} / \mathrm{s}$, with the fastest reported speeds reaching $1 \mathrm{~m} / \mathrm{s}$ (Table 2). Flood discharge generates prolonged flows that can have durations of many days to weeks. These flows are typically fully turbulent and often supercritical at peak velocities. Dilute sediment concentrations within these events often lead to the formation of interflows within thermally stratified freshwater bodies. The slow moving density flows in lakes and reservoirs typically only suspend fine sediment. Although they are prolonged, low sediment concentrations ensure that they produce mud-rich deposits that are often only a few mm thick (Crookshanks and Gilbert, 2008; Table 2). These thin deposits resemble those produced by weak and dilute oceanic flows associated with plunging river flood water (Section 7.1.3.2; Mas et al., 2010; Khripounoff et al., 2009, 2012). They differ significantly from the metre thick massive or laminated sand layers that are seen in many submarine fan sequences (Talling et al., 2012a).

7.1.4.2. Infrequent powerful flows - associated with delta-front slope failure? Lambert and Giovanoli (1988) described a fast moving ( $3 \mathrm{~m} / \mathrm{s}$; Table 2) flow that occurred in the Rhone Delta in Lake Geneva. This powerful flow occurred $\sim 12 \mathrm{~h}$ after the peak of a river flood, suggesting it was triggered by failure of recently deposited flood sediment. A well developed channel system, first noted by Forel in 1885 , extends for $\sim 10 \mathrm{~km}$ from the delta in this location. Detailed bathymetric surveys in 2008 and 2012 showed that the channel system is active with erosion and deposition of up to $4 \mathrm{~m}$, and crescentic bedforms occur along the channel floor (Girardclos et al., 2012). Well developed channel systems are rare in lakes, but the triggers and frequency of sediment flows in these settings may resemble those in submarine channel systems fed by rivers (Section 7.1.3.2; Fig. 19).

\subsection{Quantitative analysis of measured parameters}

This section explores the extent to which direct monitoring data can be used to quantitatively analyse flow character and evolution. It shows how the limited types of measurement available restrict the types of analysis that can be undertaken, especially for submarine flows. In particular, the section outlines assumptions involved in the Chezy equation that has most commonly been applied to submarine flows in the past. It cautions that these assumptions are not consistent with certain field observations, and that the layer-averaged sediment concentration predicted by the Chezy equation is unable to resolve the presence or character of denser near-bed layers.

\subsubsection{Dilute flows in lakes and reservoirs}

Monitoring of dilute and slow moving flows in lakes and reservoirs has produced relatively detailed measurements that include vertical profiles of velocity (and hence flow thickness) and sediment concentration. These measurements allow the Froude Number to be calculated, indicating 
whether flow is supercritical or subcritical (Chikita, 1989; Weirich, 1986a,b; Table 2). Flows are often (but not always) supercritical at their peak velocities (Table 2; Chikita and Okumura, 1987, 1990; Chikita, 1989, 1990; Best et al., 2005; Gilbert et al., 2006; De Cesare et al., 2006; Crookshanks and Gilbert, 2008). Flow deceleration may lead to temporal and spatial transitions to subcritical flow, presumably associated with hydraulic jumps. Calculations of Flow Reynolds Number, based on assuming a viscosity similar to that of clear water, predict that density flows are turbulent (Chikita and Okumura, 1987, 1990; Chikita, 1989, 1990; De Cesare et al., 2006). Vertical velocity and concentration gradients have been used in some locations to measure the Richardson Number that controls vertical mixing rates and the stability of density stratification (Chikita, 1989).

\subsubsection{Oceanic flows}

7.2.2.1. Types of data available for submarine flows. The types of quantitative field measurements available for submarine flows can be split into a series of general classes (Table 1 ). There are arguably four key parameters for submarine flows; (1) flow velocity, (2) flow thickness, (3) sea floor gradient, and (4) sediment concentration that determine flow density in conjunction with sediment grain density. A final key parameter is the grain size distribution, especially the volume fraction of cohesive fine mud.

In many cases, only the average frontal flow velocity is available from cable breaks. In a smaller number of examples, more detailed velocity data is available at a point. Current meters can provide velocity measurements for a single height above the bed, whilst ADCPs can provide a vertical velocity profiles that also serve to constrain flow thickness (Xu, 2011; Cooper et al., 2013). However, flow thickness is often poorly constrained, with only crude information from erosional trim lines, the height to which deposits drape up topography, or the depth of submarine channels. Some information on the sea floor gradient is known for most monitoring datasets. However, as higher resolution surveying techniques are showing (Paull et al., 2011, 2012), the seafloor within submarine channels is commonly very complex and the existing gradient data derived from regional surveys may be over smoothing the real seafloor gradients. Measurements of sediment concentration and flow density, has only been made at five locations: Monterey and Mugu Canyons (Xu et al., 2004, 2010; Xu, 2011), Gaoping Canyon (Liu et al., 2012), Squamish River Delta (Hughes Clarke et al., 2012), and Var Canyon (Khripounoff et al., 2012). These concentration values are based on optical or acoustic backscatter measurements, which need to be calibrated for grain size (Xu et al., 2010; Xu, 2010, 2011) and which is a technique that only works at low ( $\ll 5$ vol.\%) sediment concentrations. The available sediment concentration measurements come from the upper reaches of canyons or delta fronts. Sediment concentration has never been measured for flows that run out beyond the continental slope, and these are the flows that deposit sediment on submarine fans. This lack of information on sediment concentration hampers quantitative analyses of submarine flows, and means that Froude, Reynolds and Richardson Numbers can very rarely be calculated.

7.2.2.2. Chezy equation. A relationship between flow speed, seafloor gradient, flow thickness, vertically-averaged sediment concentration (flow density), and a friction factor can be derived by assuming that the down-slope gravitational driving force is locally balanced by frictional resistance to flow. This forms the basis of the well known Chezy equation that has been applied to submarine density flows (Kuenen, 1952; Middleton, 1966; Komar, 1969, 1977; Bowen et al., 1984; Prior et al., 1987; Ren et al., 1996; Xu, 2010; Khripounoff et al., 2012). This equation can be expressed (Bowen et al., 1984) as;

$\mathrm{U}^{2}=\frac{\rho_{\mathrm{s}}-\rho}{\rho} \mathrm{c} \cdot \mathrm{g} \cdot \mathrm{h} \frac{\sin \beta}{(1+\alpha) \mathrm{f}}$

where $U$ is the depth-averaged velocity in the body of the flow $(\mathrm{m} / \mathrm{s}), \rho_{\mathrm{s}}$ is the density of sediment $\left(\sim 2600 \mathrm{~kg} / \mathrm{m}^{3}\right), \rho$ is the density of water $\left(\sim 1000 \mathrm{~kg} / \mathrm{m}^{3}\right)$, c is the depth-averaged volume fraction of sediment in the flow (dimensionless), $g$ is the gravitational constant $\left(9.81 \mathrm{~m} / \mathrm{s}^{2}\right)$, $\mathrm{h}$ is the flow thickness $(\mathrm{m}), \beta$ is the sea floor gradient $\left({ }^{\circ}\right), \alpha$ is a constant defining the ratio of drag at the top and base of the flow (dimensionless), and $\mathrm{f}$ is the basal drag coefficient (dimensionless).

In the case of rivers, the empirical friction constant in the Chezy equation is well constrained by empirical observations. This is not the case for submarine flows, and considerable uncertainty surrounds the values use for $\alpha$ and $\mathrm{f}$ (Komar, 1969). Values of $\alpha=0.43$ and $\mathrm{f}=0.003$ have been assumed in previous work, based on measurements in experiments and rivers (Bowen et al., 1984).

7.2.2.3. Assumptions implicit in the Chezy equation. The assumptions behind the Chezy equation deserve careful consideration. This equation does not account for the dissipation of momentum acquired further up-slope. For instance, it predicts that turbidity currents will not flow along horizontal gradients, or be able to travel upslope. There is field evidence that turbidity currents can sometimes travel for long distances $(>100 \mathrm{~km}$ ) upslope, due to both inherited momentum and flow thickness (Underwood, 1991; Amy and Talling, 2004; Talling et al., 2007b; Hunt et al., 2011). This suggests that momentum inherited from steeper gradients in proximal areas may contribute significantly to the speed and run-out of some turbidity currents. The sensitivity to localised changes in the seafloor gradient associated with complexities in submarine channels is poorly understood.

The effects of flow viscosity and yield strength are also neglected in the approach based on the Chezy equation, in which the flow velocity and friction coefficient are independent of viscosity. This may be a reasonable assumption for rivers or very dilute submarine flows, but many submarine flow deposits record evidence for debris flow phases or high density turbidity currents with elevated sediment concentrations (Talling et al., 2012a). Viscosity may become an important factor in determining flow velocity in these higher concentration flows. Moreover, deposits show that many submarine flows contain significant volumes of cohesive mud (Talling et al., 2012a). A small amount of cohesive mud can change flow viscosity by several orders of magnitude, as can changes in shear rates (Coussot, 1997). In these situations, flow viscosity may have a profound effect on flow velocity. These assumptions need to be kept in mind, as they may lead to estimates of flow parameters that are erroneous.

7.2.2.4. Analysis of field datasets using the Chezy equation. Monitoring datasets based on cable-breaks typically include the frontal flow velocity together with measurements of sea floor gradient. The Chezy equation (Eq. (1)) was developed originally for the body of a flow (see Middleton, 1966; Benjamin, 1968; Komar, 1977; Bowen et al., 1984). However, as with previous work, we use measurements of frontal flow speed.

The Chezy equation will predict the product of flow thickness and vertically averaged sediment concentration if flow speed and seafloor gradient are known, together with the values of frictional coefficients $\alpha$ and $f$ (Table 3). The flow speed should be proportional to the square root of sea floor gradient according to the Chezy equation, if the product of flow thickness and layer-averaged sediment concentration remains constant. A plot of flow speed against the square root of sea floor gradient (Fig. 20b) suggests that the thickness-concentration product decreased in a down-flow for the 1929 Grand Banks event, the 1979 event offshore Nice, and flow events in Bute Inlet. This may be due to flow widening and thinning, rather than decreasing sediment concentration and dissipation (Parker, 1982). In contrast, the thickness-concentration product shows less variation in the 2006 and 2009 events offshore Taiwan that were confined within canyons of more constant width.

7.2.2.5. Use of the Chezy equation to estimate layer-averaged sediment concentration. Field measurements of flow thickness allow depth-averaged sediment concentrations to be calculated using Eq. (1) (Table 3). Xu 
Table 3

Flow analysis based on the Chezy equation (Eq. (1)).

\begin{tabular}{|c|c|c|c|c|c|c|}
\hline $\begin{array}{l}\text { Location and } \\
\text { date of flow }\end{array}$ & Reference & $\begin{array}{l}\text { Measured } \\
\text { flow velocity } \\
(\mathrm{m} / \mathrm{s})\end{array}$ & $\begin{array}{l}\text { Measured } \\
\text { seafloor } \\
\text { gradient } \\
\qquad\left(^{\circ}\right)\end{array}$ & $\begin{array}{l}\text { Depth x slope } \\
\text { product }(\mathrm{m}) \text { from } \\
\text { Chezy equation }^{\mathrm{a}}\end{array}$ & $\begin{array}{l}\text { Measured } \\
\text { flow } \\
\text { depth } \\
\quad(\mathrm{m})\end{array}$ & $\begin{array}{l}\text { Layer-averaged } \\
\text { sediment volume } \\
\text { concentration } \\
\text { from Chezy equation }\end{array}$ \\
\hline \multirow{4}{*}{ Grand Banks 1929} & \multirow{4}{*}{$\begin{array}{l}\text { Heezen \& } \\
\text { Ewing, 1952; } \\
\text { Piper et al., } \\
1988 \\
\end{array}$} & 19.1 & 0.3 & 0.3374 & & \\
\hline & & 8.2 & 0.15 & 0.1230 & & \\
\hline & & 6.2 & 0.08 & 0.1314 & & \\
\hline & & 3 & 0.05 & 0.0492 & & \\
\hline \multirow{2}{*}{ Nice 1979} & \multirow{2}{*}{$\begin{array}{l}\text { Piper \& } \\
\text { Savoye, } 1993\end{array}$} & 7 & 1.4 & 0.0136 & & \\
\hline & & 1.8 & 0.12 & 0.0074 & & \\
\hline \multirow{3}{*}{ Taiwan 2006} & \multirow{3}{*}{ Hsu et al., 2008} & $20($ flow 1$)$ & 1 & 0.1299 & & \\
\hline & & 3.7 (flow 2) & 0.2 & 0.01887 & & \\
\hline & & 5.7 (flow 2) & 0.24 & 0.0374 & & \\
\hline Taiwan 2008 & Liu et al., 2012 & 1.6 & 1.1 & 0.00079 & & \\
\hline \multirow{5}{*}{ Taiwan 2009} & \multirow{5}{*}{$\begin{array}{l}\text { Carter et al., } \\
\text { 2012; Gavey, } 2012\end{array}$} & 16.6 (flow 1$)$ & 1.1 & 0.0845 & & \\
\hline & & 10.2 (flow 2 ) & 0.05 & 0.5689 & & \\
\hline & & 5.4 (flow 2) & 0.18 & 0.0445 & & \\
\hline & & 8.2 (flow 2 ) & 0.2 & 0.0925 & & \\
\hline & & 6.55 (flow 2) & 0.2 & 0.0590 & & \\
\hline \multirow{2}{*}{ Zaire 2004} & \multirow{2}{*}{$\begin{array}{l}\text { Vangriesheim } \\
\text { et al., } 2009\end{array}$} & 3.5 & 0.23 & 0.0147 & & \\
\hline & & 0.7 & 0.1 & 0.0013 & & \\
\hline \multirow[t]{2}{*}{ Bute Inlet } & \multirow{2}{*}{ Prior et al., 1987} & 3.35 & 0.71 & 0.0047 & 40 & 0.0001 \\
\hline & & 0.75 & 0.58 & 0.0003 & 40 & 0.00007 \\
\hline Gioia Canyon & $\begin{array}{l}\text { Colantoni et } \\
\text { al., } 1992 \\
\end{array}$ & 4.5 & 2.3 & 0.0074 & & \\
\hline Mugu Canyon & Xu, 2010 & 0.8 & 2.8 & 0.0005 & 10 & 0.00005 \\
\hline Hueneme Canyon & Xu, 2010 & 1.5 & 2.1 & 0.0007 & 20 & 0.00004 \\
\hline Monterey Canyon & Xu et al., 2004 & 1.9 & 1.8 & 0.0010 & 65 & 0.00002 \\
\hline Squamish Delta & $\begin{array}{l}\text { Hughes } \\
\text { Clarke et al., } 2012\end{array}$ & 1.5 & 1.9 & 0.0006 & & \\
\hline
\end{tabular}




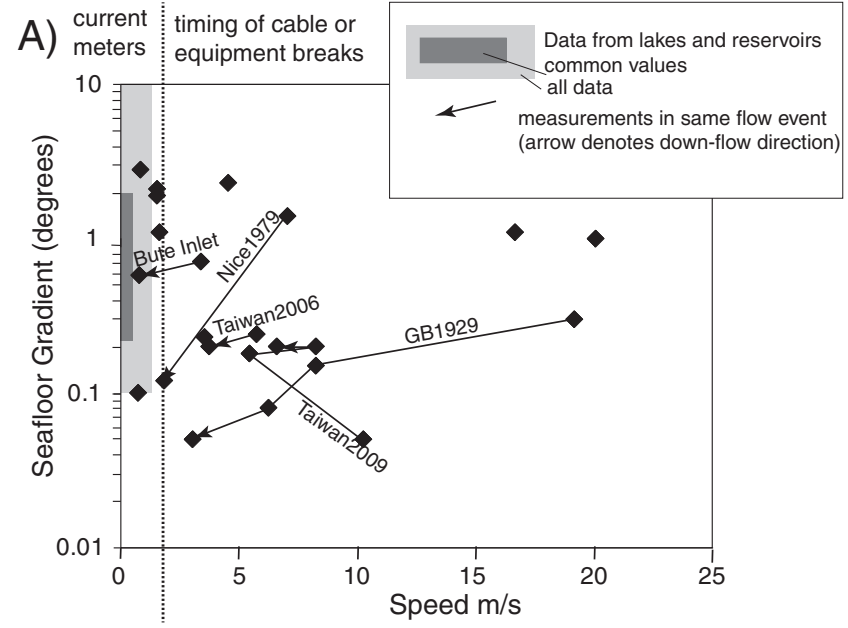

B)

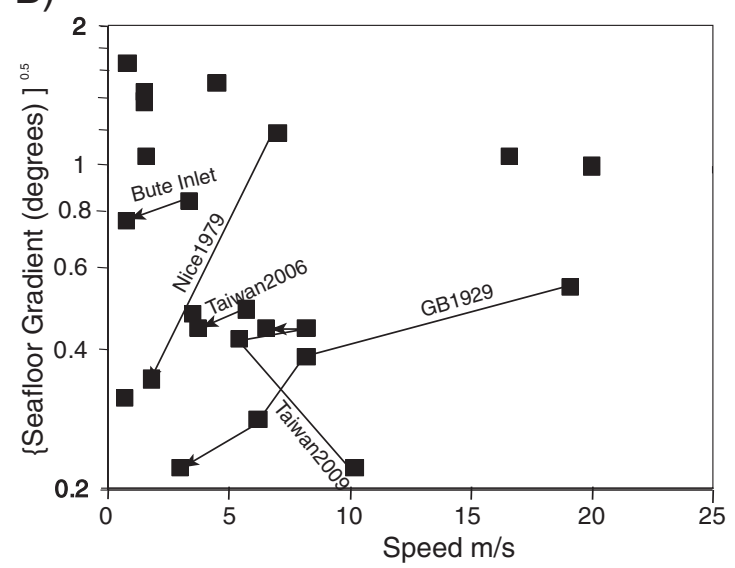

Fig. 20. (A) Plot showing the relationship between seafloor gradient and flow velocity for submarine flows (Table 1 ). The dashed line corresponds to a flow speed of $\sim 1.8 \mathrm{~m} / \mathrm{s}$ that separates measurements made by cable breaks and by moored current meters. Measurements from the same event are indicated by a connecting line, with an arrow indicating the down flow direction. (B) Plot of the square root of sea floor gradient against flow velocity for the same observations. The Chezy equation (Eq. (1)) implies that the square root of seafloor gradient will be proportional to flow velocity, if frictional coefficients, flow width, flow depth, and layer averaged sediment concentration remain constant.

(2010) used relatively precise measurements of flow thickness from ADCP data to calculate depth-averaged sediment volume concentrations of $<0.01 \%$ for events in Mugu and Hueneme Canyons (Table 3 ). Similarly low sediment concentrations were calculated by Prior et al. (1987) for a flow in Bute Inlet (Table 3). Bowen et al. (1984; their figure 12) summarise estimates of volume sediment concentration that range from $5 \%$ to $0.1 \%$ from events on the Navy Fan, Monterey Canyon (Komar, 1969), Laurentian Fan (Stow and Bowen, 1980), and Silver Abyssal Plain (Van Tassell, 1981).

The sediment concentrations derived by this approach tend to be very dilute. However, this is a layer-averaged sediment concentration value, and much higher concentration layers could exist near to the bed. Due to uncertainties in the frictional parameters ( $\alpha$ and $\mathrm{f}$ ), and the assumption implicit in the Chezy approach (Section 7.2.2), it is difficult to assess the accuracy of these estimated vertically-averaged sediment concentrations.

7.2.2.6. Datasets including temporal changes in flow velocity at a point (current meters). Current meters provide information on velocity at a single place, and how that velocity various through time. Individual ADCP measurements reflect the average of measurement periods lasting several seconds, and these periods are usually are separated by minutes (Xu, 2011; Cooper et al., 2013). They thereby document temporal changes in flow speed (waxing, steady, or waning) and flow duration (Table 1).

Temporal changes in flow speed show considerable variation, and there is limited data from which to extract generalised signatures of flow speed for different types of event. However, flow events in Monterey, Mugu and Hueneme Canyons showed a consistent trend, with maximum flow velocities occurring close to the front of the flow, followed by decay in flow speed over several hours (Xu et al., 2004; Xu et al., 2010; Xu, 2010, 2011). Flows that were triggered by delta front failure on Squamish River Delta showed a similar trend (Hughes Clarke et al., 2012, in press), as do prolonged flow in Zaire Canyon (Cooper et al., 2013). In contrast, the submarine flows associated with hyperpycnal flood discharge displayed a waxing and waning flow speed in the head of Gaoping Canyon in 2008 (Liu et al., 2012). The flood related submarine flows documented offshore from the Var River also waxed and waned, but with a more complex pattern of multiple peaks (Khripounoff et al., 2009). The very dilute submarine flow generated by the Tokachi-oki earthquake offshore Japan in 2003 started with near-steady flow for several hours before flow speed declined (Mikada et al., 2006).

7.2.2.7. Datasets including vertical velocity profiles (ADCPS). ADCPs also provide data on the vertical flow velocity. Xu (2010b) showed that the vertical velocity profiles for flows in the Monterey, Mugu and Hueneme Canyons indicate supercritical flow, through a comparison to velocity profiles from supercritical and subcritical laboratory flows.

7.2.2.8. Datasets including sediment concentration measurements. There are only four locations where measurements of sediment concentration have been collected, and the available measuring techniques are restricted to low sediment concentrations. These four locations all show that turbid water may persist for hours after the down-slope flow velocity has declined to near zero (Xu et al., 2004; Xu, 2010, 2011; Hughes Clarke et al., 2012; Liu et al., 2012). The low sediment concentrations measured in Monterey, Mugu, and Hueneme Canyons are consistent with supercritical and fully turbulent flow (Xu et al., 2004; Xu, 2010).

7.2.2.9. Is there evidence for ignition or dissipation?. It has been proposed that turbidity currents tend towards one of two states depending on whether they are eroding or depositing sediment (Parker, 1982). Flows that initially erode will become denser, and therefore travel even faster, leading to increased erosion. This positive feedback that leads to flow acceleration has been termed ignition. Conversely, if sediment is deposited from the flow, it will become less dense and travel more slowly. This may lead to further sediment deposition, and such deceleration has been termed dissipation (Parker, 1982). There are a limited number of data sets that include spatial changes in frontal flow velocity that may be used to evaluate whether flows ignite or dissipate.

The most detailed datasets come from the flows offshore Taiwan in 2006 and 2009 that travelled down the Gaoping Canyon. The 2006 flow travelled at $\sim 3.6 \mathrm{~m} / \mathrm{s}$ for over $50 \mathrm{~km}$, before accelerating to a speed of $\sim 5.7 \mathrm{~m} / \mathrm{s}$ for a subsequent $\sim 100 \mathrm{~km}$. However, this increase in flow velocity is accompanied by an increase in sea floor gradient (Fig. 5), suggesting that it might not be due to erosion and increased sediment concentration due to ignition. The 2010 flow displayed irregular changes in velocity from $10.3 \mathrm{~m} / \mathrm{s}$ to $5.4 \mathrm{~m} / \mathrm{s}$ to $8.2 \mathrm{~m} / \mathrm{s}$ and finally to $6.7 \mathrm{~m} / \mathrm{s}$ (Fig. 11), which could potentially be due in part to delayed breakage of cables after the flow front had passed. However, both the 2006 and 2009 flows showed relatively small changes in their average flow speed over long distances, suggesting that the flow in these canyon confined flows was relatively uniform with speeds between 3.6 and $5.7 \mathrm{~m} / \mathrm{s}$ for $\sim 250 \mathrm{~km}$.

In contrast, the frontal velocity of the 1929 Grand Banks event declined progressively from $19 \mathrm{~m} / \mathrm{s}$ to $8 \mathrm{~m} / \mathrm{s}$ to $6 \mathrm{~m} / \mathrm{s}$ and finally to $3 \mathrm{~m} / \mathrm{s}$ (Fig. 1). This decrease in speed could have been due to sediment deposition and dissipation. However, the decrease in flow speed may 
have also been due simply to the flow becoming wider and more poorly confined as it exited the fan-valleys and reached the Sohm Abyssal Plain and the gradient decreased to $<0.1^{\circ}$ (Fig. 1).

\subsection{Turbidity currents: the most poorly monitored major transport process on Earth?}

The previous sections have tried to bring together available monitoring datasets to outline how turbidity currents can be triggered, and how their internal structure evolves. Perhaps an even more fundamental question is how well documented are turbidity currents, and how well tested are our conceptual, experimental or numerical models that capture such understanding? Are turbidity currents well documented in comparison to the other major sediment transport processes? The following section considers these questions for different types of turbidity current, for which there are variable amounts of monitoring data.

\subsubsection{Turbidity currents in lakes and reservoirs}

Dilute $(<0.001$ vol.\%) and slow moving $(<0.5 \mathrm{~m} / \mathrm{s})$ turbidity currents that are generated by river flood discharges into lakes and reservoirs have been relatively well documented (Table 2 ) due to their more accessible location, because they tend not to damage instruments or moorings, and because these dilute sediment concentrations favour concentration measurements. This information sometimes includes vertical velocity structure (and its change through time), turbulence structure, flow thickness, sedimentation rates and deposit character. More attempts are needed, using instrumentation developed for marine flows, for more powerful flows in well defined channels, building on the single previous study of such flows by Lambert and Giovanoli (1988).

\subsubsection{Submarine turbidity currents}

Submarine turbidity currents have been more sparsely monitored than flows in lakes and reservoirs. It is apparent from this data compilation that the timing of flows, and hence the most likely causes of flow initiation, are easier to document than their internal characteristics.

For instance, arguably the most important information for characterising a turbidity current is the vertical profile of sediment concentration and grain size. This is because sediment concentration and grain size (especially the cohesive finer-mud component) strongly influence flow density, flow rheology, particular support processes and mixing or entrainment rates. Sediment concentrations have been measured in just four locations in canyons or delta fronts based on light transmission or ADCP backscatter data, with the calibrated for the scattering effects of grain size (Xu et al., 2004; Xu, 2010, 2011; Hughes Clarke et al., 2012; Liu et al., 2012; also see Cooper et al., 2013, but who do not present their ADCP backscatter data). Uncertainties in this calibration may be significant, as multiple frequencies were not available to help constrain the affects of variable grain size on backscatter signals ( see Section 7.4.3). The data come from single locations along the flow path, so that spatial evolution of concentration cannot be assessed. The techniques used are unable to penetrate into higher concentration ( $\gg 5$ vol.\%) layers near the bed, so the presence and character of such layers is very poorly known. The sediment concentration of flows that runs out beyond the continental slope has never been measured directly.

7.3.2.1. Long run-out oceanic turbidity currents that reach submarine fans. Fast moving flows that run-out beyond the termination of submarine canyons are especially difficult to monitor, as they are both infrequent and are sufficiently powerful to destroy equipment placed directly in their path. These flows have been monitored directly in just five locations offshore from the Grand Banks, Nice Algerian Margin, SE Taiwan, and Zaire. The only parameters measured in this type of flow are the average frontal flow speed and associated sea floor gradients, together with estimates of flow thickness and flow width from sea floor mapping. Their internal character is very poorly constrained, and their sediment concentration has never been measured directly. Sedimentary deposits and erosional structures created by these events provide further important information on flow evolution, although we still await a comprehensive set of cores for any of these long run-out events. The frequent occurrence of long run-out flows in the Gaoping Canyon offshore SE Taiwan may provide the best opportunity for future more detailed monitoring studies.

7.3.2.2. Shorter run-out canyon-filling events - mainly associated with large wave heights. More types of information are available for annual or sub-annual events that infill submarine canyons, and charge the canyon with sediment, which includes vertical velocity profiles that also constrain flow thicknesses and duration (Xu et al., 2004; Xu, 2011), detailed studies of the episodic motion of objects placed on the canyon floor (Paull et al., 2010a), bathymetric surveys showing the character and motion of bedforms or occurrence of canyon head slides (Marshall, 1978; Smith et al., 2005, 2007; Xu et al., 2008; Paull et al., 2010a, 2011, 2012), ROV or direct observations by divers of the mechanical properties of loaded canyon floor sediment (Dill, 1964; Shepard and Dill, 1966; Paull et al., 2012).

In addition to continued monitoring of sediment transport processes in sand-filled canyons, further monitoring is needed to document how muddy sediment is moved into deeper water through offshore canyons, extending the work of Mullenbach et al. (2004) and Puig et al. (2004) in Eel Canyon. The less frequent and more powerful flows that flush sediment from these various types of canyons are yet to be monitored in action. Their infrequency, unpredictable occurrence, and powerful character ensure that they will continue to be difficult to monitor in the future, but observatories of the type deployed off Japan and British Columbia may offer the best opportunity for monitoring. Mapping of deposits may continue to provide much of the information available for canyon flushing events.

7.3.2.3. Flows associated with river systems. Significant advances have been made in the monitoring of river fed system (cf. Inman et al., 1976), especially those associated with Canadian fjord-head deltas (Prior et al., 1987; Zeng et al., 1991; Bornhold et al., 1994; Ren et al., 1996; Hill, 2012; Hughes Clarke et al., 2009, 2012, in press). This work is providing a clearer picture of how flows are triggered on delta fronts, and the relative importance of delta-front failure and direct plunging of hyperpycnal river flood water (cf. Forel, 1885). The relatively low costs of working in compact shallow water fjord-head systems makes them attractive for monitoring studies, where delta-front flows can also generate upslope migrating crescentic bedforms, and in some locations are powerful enough to produce extensive submarine channels. Future challenges include imaging of dense near bed layers, and understanding how the character and frequencies of events changes are one moves away from the delta front. There is a still a need for more detailed studies that monitor flow character in larger river fed systems such as in the Var and Gaoping Canyons.

\subsubsection{Comparison to other major sediment transport processes on Earth}

The amount of direct monitoring information available for turbidity currents often contrasts strongly with that available for other major sediment transport processes, especially rivers. The suspended sediment concentration and velocity profiles of rivers are routinely measured at gauging stations across major river networks. Test sites have been established with notable success for other types of mass flow such as terrestrial debris flows and snow avalanches (Iverson et al., 2007; Sovilla et al., 2008; Iverson et al., 2010). Glacier and ice sheet flow has been widely monitored (e.g. Iverson et al., 2007) and depositional processes are relatively well constrained. Even pyroclastic flows, lahars and surges associated with volcanic eruptions have all been captured by video cameras; whilst there are no photographic images of turbidity 
currents, given the low field of vision in the deep sea. Caldera-forming eruptions are perhaps the only other process that is yet to be photographed, which can transport such large amounts of sediment $\left(>100 \mathrm{~km}^{3}\right)$ for such long distances $(>100 \mathrm{~km})$.

\subsection{Future strategies for monitoring turbidity currents}

We conclude by considering future approaches to monitoring turbidity currents.

\subsubsection{Flow timing and triggers}

This contribution illustrates that it is often easier to determine the timing of submarine flows, and therefore how they are triggered, than to measure their internal characteristics such as sediment concentration or flow state. Considerable advances have been made in recent years towards understanding the varied way in which flows can be triggered, and their frequency. This includes work in Monterey Canyon (Figs. 7 and 9; Paull et al., 2010a,b; Xu, 2011), Bute Inlet (Fig. 12; Prior et al., 1987), and the Squamish and Fraser River deltas (Figs. 14 and 16; Hill, 2012; Hughes Clarke et al., 2012, in press). In contrast, there are still no direct measurements of sediment concentration from flows that reach the submarine fans. Documenting the timing and triggers of flows may continue to be a more tractable objective for future monitoring studies.

The timing of flows has been documented by transmissometers, ADCPs, or other sensors deployed on moorings (e.g. Prior et al., 1987; Hughes Clarke et al., in press; Figs 13 and 16). Designing moorings that can withstand fast moving flows is more difficult, and almost all previous data comes from instruments or cables that have been broken by the flow (Table 1). The most effective strategy may be to design instruments that simply releasing a component that rises to the sea surface and transmit information on event timing. This type of instrument has already been designed and deployed successfully by the Monterey Bay Aquarium Research Institute (MBARI) in Monterey Canyon (Bird et al., 2007). These instruments are relatively inexpensive $(<£ 4000)$ and can be deployed at multiple locations along a flow path. They provide information on frontal flow speeds, run out distances, frequency of occurrence and the trigger mechanism, and could be deployed in widespread locations worldwide. The deployment of concrete blocks with acoustic beacons provides an additional method for documenting the timing of flows, through relocation of the beacons (Paull et al., 2010a), and potentially by monitoring the accelerations and changes in orientation during the transport events.

Submarine cable breaks are likely to continue to play an important role in understanding the triggers for submarine flows (e.g. Carter et al., 2012). It may become possible to deploy scientific sensors within the repeater nodes for these cables, and monitor the acoustic signature generated by submarine flows. A preliminary study by MBARI to monitor the sound emitted by submarine flows is underway in Monterey Canyon. Such approaches would avoid the issue that submarine cable breaks only record flows that are fast enough to break cables, which tend to have speeds in excess of $\sim 2 \mathrm{~m} / \mathrm{s}$.

Repeated surveys that collect detailed swath bathymetry have proven to be a very powerful tool for understanding flow frequency and triggers, and changes in flow path morphology (Paull et al., 2010a; Hill, 2012; Hughes Clarke et al., 2012, in press). This type of work uses existing technology, and should be broadened to a wider range of locations.

Previous monitoring has shown how the timing of flows can provide powerful insights into how flows are triggered. For instance, flows that occur after floods have ceased and are generated by delta slope failure rather than plunging of hyperpycnal flood water (Figs. 12 and 14; Prior et al., 1987; Hughes Clarke et al., 2012). Further work is needed to explore this relationship, and understand the causes of such delayed slope failure, noting that delta-lip failures can also coincide with individual flood peaks (Hughes Clarke et al., 2012, in press). Not all large earthquakes appear to generate extensive failure of the sea floor
(Sumner et al., 2013). A better understanding is therefore needed of the types of earthquake that trigger long run out submarine flows, using locations (e.g. Taiwan) where detailed information is available on earthquake location and character. Such work will help to determine the degree to which submarine flow deposits provide a long term record of past earthquakes (Goldfinger et al., 2007; Atwater and Griggs, 2012; Sumner et al., 2013).

\subsubsection{Ignition or dissipation}

A key question that may be tractable is whether submarine flows erode and accelerate (ignite), or deposit and decelerate (dissipate; Parker, 1982). A series of event detectors placed along the flow path would be needed to record spatial changes in flow velocity. The affects of changes in sea floor gradient and flow width would need to be isolated, in order to determine whether changes in flow speed resulted from variations in the sediment load carried by the flow.

\subsubsection{Flow character}

Previous work suggests that documenting the internal state and composition of submarine flows is even more challenging than documenting their timing and triggers. Recent advances have been made in measuring velocity profiles using upward or downward pointing ADCPs on tripods or moorings (Xu et al., 2004; Xu et al., 2010; Xu, 2010, 2011; Cooper et al., 2013). However, these measurements are restricted to slower moving flows, and flows with sufficiently low sediment concentrations ( $\ll 5$ vol.\%) to allow penetration by ADCPs (Hurther et al., 2011).

Sediment concentration is perhaps the most fundamental parameter for understanding the character of submarine flows as it influences flow state (e.g. intensity of turbulence), rheology, sediment support mechanism(s), and processes of sediment deposition or re-entrainment. However, the almost complete absence of sediment concentration measurements substantially hampers our understanding of what submarine flows are.

Recent work has shown how acoustic backscatter signals from ADCPs or swath multibeam data can document relative changes in sediment concentration (Kostaschuk et al., 2005; Xu, 2010; Hughes Clarke et al., 2012). However, obtaining absolute measurements of sediment concentration is more difficult, as the backscatter intensity is also dependent on the grain sizes within the flow. Recent work has made advances in calibrating backscatter data for variable grain sizes, using information from multiple source frequencies (Hurther et al., 2011; Guerrero et al., 2012). The use of ADCP backscatter data has the major advantage that information is collected simultaneously on sediment concentration and velocity profiles, and this is a promising avenue for future research. However, previous work has used ADCPs that can only penetrate relatively dilute ( $\ll 5$ vol.\%) sediment flows (Hurther et al., 2011). They are unable to determine the presence or absence of higher concentration near-bed layers. Flow deposits that contain planar laminated or massive sand intervals (Bouma $T_{A}$ and $T_{B}$ intervals) suggest that dense near bed layers may be common (Talling et al., 2012a), and understanding their character is an important research goal. There is a need to develop techniques that see through overlying dilute sediment clouds to image denser near bed layers, perhaps using acoustic profiles with low frequencies than existing ADCPs.

Other approaches for monitoring the character of dense near-bed layers include implanting devices in the seafloor that record the acceleration and orientation during flow event may reveal how clasts are carried by the dense flow. This type of sensor is being developed by MBARI. As suggested by Xu (2011), tracking of particles within a flow as they pass stationary receivers could also provide key information on how sediment is being transported.

\subsubsection{Complex spatial evolution of flow character}

Mapping of individual submarine flow deposits (Amy and Talling, 2004; Talling et al., 2007a,b, 2012a; Sumner et al., 2012) and laboratory experiments (Sumner et al., 2009) emphasises that the internal of 
submarine flows can change significantly along the flow path. A single flow can comprise several different types of flow (e.g. debris flow and turbidity current), with transformation from dilute-to-dense or denseto-dilute flow (Talling et al., 2004, 2012a,b; Haughton et al., 2009). Future studies that aim to capture these important down-flow changes will need to monitor multiple sites along the flow path, using a source-to-sink approach.

\subsubsection{Diversity of flow types and choice of monitoring locations}

The choice of monitoring locations is a key issue. There are relatively few locations flows are likely to occur during the period of a typical research grant. Some locations are better suited for the repeated deployment of research vessels, ROVs, AUVs, or other research infrastructure. In a few locations, cabled observatories may provide opportunities for high frequency measurements in the future, such as using the VENUS observatory on the Fraser River delta (Lintern and Hill, 2010). Future locations where monitoring efforts might be focussed include Monterey Canyon, Gaoping Canyon offshore SE Taiwan, Squamish and Fraser River deltas, or reservoirs along the Yellow River that are fed by hyperconcentrated sediment suspensions see Wei et al., 2013 for initial work on dilute flows). However, this review emphasises the diversity of submarine flows that have variable triggers, sediment composition, run out distances, and speeds. Such diversity is unsurprising as similar diversity is seen in subaerial sediment density flows, which range from rivers to debris flows to slope failures. The diversity in submarine flows suggests that monitoring efforts need to address a reasonably wide range of locations, rather than becoming focussed at just one or two sites.

\subsubsection{Limitation of monitoring data from very dilute flows in lakes and reservoirs}

Many of the most detailed monitoring data sets come from lakes and reservoirs, where dilute $(<0.01 \%$ sediment volume $)$ and slow moving $(<50 \mathrm{~cm} / \mathrm{s})$ flows are typically observed. However, the behaviour of these dilute and rather weak flows may differ significantly from more powerful flows that reach submarine fans, which may often have higher sediment concentration near bed layers that deposit thick sand layers ( $\mathrm{T}_{\mathrm{A}}$ and $\mathrm{T}_{\mathrm{B}}$ intervals; Talling et al., 2012a).

The initially-powerful, long run-out flows that deposit sediment across submarine fans will continue to be intrinsically difficult to study, due to their scale and ability to destroy instruments. However, it is important to understand these flows as they produce thick sediment accumulations in the rock record, some of which now host important hydrocarbon reserves. One future strategy might be to monitor the less powerful distal part of long run out events, which have flow speeds of less than 1 to $2 \mathrm{~m} / \mathrm{s}$ that instruments can withstand.

\subsubsection{The need for coupling of flow monitoring data to studies of the flow deposit}

Analyses of flow deposits can help us to understand the character of flows, and how they evolve spatially. The most effective approach may be to combine insights from both the deposit and from flow monitoring. There are currently very few studies that combine monitoring data with deposit geometry (e.g. Crookshanks and Gilbert, 2008), and even in the case of the 1929 Grand Banks event the distal deposit is rather poorly characterised. Such cores may need to be precisely located (perhaps using ROV-based corers; Paull et al., 2001, 2005), especially in areas of more complex sea floor terrain such as submarine canyons or channel floors. Repeated mapping such as that done in the Monterey Canyon can also play a key role for understanding intervening flow events (Paull et al., 2010a, 2011).

A relatively simple objective is to better constrain the deposit geometry of events for which we already have information on flow speeds from cable breaks, such as the 1929 Grand Banks event or the 2006 event offshore Taiwan, and for which changes in sea floor gradient, flow depths and flow widths can be documented. This may involve the development of coring technology (e.g. vibracoring) that is capable of penetrate relatively thick sand deposits. For example, piston or gravity coring has thus far been unable to penetrate large areas of the 1929 Grand Banks deposit in the Sohm Abyssal Plain. A ROV-based vibracorer has been built and tested by MBARI that allows precise coring and penetration of sandy areas of the sea floor, and a similar system is about to be tested on the UK ROV ISIS. This ROV-vibracoring technology will become more widely available for science worldwide.

\section{Conclusions}

Submarine sediment density flows are one of the volumetrically most important processes for transporting sediment across our planet, yet they are also one of the most sparsely monitored. It is apparent that documenting the timing and triggers of sediment density flows is less problematic than determining their internal composition and flow state, although weak and frequent flows remain the easiest to monitor. Considerable advances have been made in understanding how flows are triggered (e.g. Figs. 12 and 14). However, the sediment concentration of submarine flows that run out beyond the continental slope has still never been measured, in any location. This paucity of monitoring information contrasts with that available for most other major sediment transport processes, and ensures that models for submarine flows remain poorly tested.

This synthesis of direct monitoring data illustrates the diverse nature of submarine sediment density flows, which can be subdivided into a series of different types (Fig. 19). The limited amount of direct monitoring data means that generalisations must still be treated with caution and it may be that not all important types of flows have been monitored. Submarine slope failures can generate fast moving (up to $20 \mathrm{~m} / \mathrm{s}$ ) sediment flows that run out for hundreds of kilometres into the deep ocean. Both very large $\left(>100 \mathrm{~km}^{3}\right)$ and relatively small $\left(0.008 \mathrm{~km}^{3}\right)$ volume failures in canyon heads can generate flows that travel at several $\mathrm{m} / \mathrm{s}$ (Fig. 19a). Slope failure may be triggered by major earthquakes or by rapid sediment deposition. Shorter run-out $(<50 \mathrm{~km})$ flows can occur many times each year in submarine canyons fed by sand from the shelf (Fig. 19b). These canyon-confined events are typically associated with periods of large waves. They generate extensive trains of crescentic bedforms that migrate upslope. The origin of these bedforms is contentious, but they most likely form through retrogressive breaching of a dense, liquefied, near-bed sediment layer that generates cyclic hydraulic jumps (Paull et al., 2010a). Expanded dilute flows that are supercritical and fully turbulent also occur within these canyons (Xu et al., 2004; $\mathrm{Xu}, 2011)$. The canyons are flushed by much more infrequent flows of unknown character that deposit sediment across submarine fans.

Powerful long run-out flows can also occur in systems fed by river floods, but the only available field dataset from offshore SE Taiwan shows that the long run-out flow was not associated with plunging hyperpycnal flood waters, but rather occurred several days after flood discharges finished, and most likely resulted from failure of rapidly deposited sediment in the canyon head (Carter et al., 2012). Monitoring of submarine deltas shows that intermediate run-out submarine flows are not necessarily associated with individual flood discharge peaks, although the submarine flows tend to occur during the flood season (Prior et al., 1987; Hill, 2012; Hughes Clarke et al., 2012). Tens of submarine flow events can occur each year on these delta fronts, and they also generate trains of crescentic shaped bedforms that migrate upslope.

Discharge of hyperpycnal river floodwater in the ocean can generate submarine sediment density flows, which are often sustained for up to several days (Liu et al., 2006, 2012). These submarine flows are relatively dilute, and available data suggest they can transport fine sand, but that most deposit thin layers of muddy sediment (Liu et al., 2012). Sediment density flows in lakes and reservoirs generated by river floods have been monitored in much greater detail. They are typically very dilute $(<0.01 \mathrm{vol}$ \% sediment) and travel at up to $50 \mathrm{~cm} / \mathrm{s}$, and are prone to 
generating interflows within the density stratified water mass. They typically deposit thin and fine grained muddy laminae (Crookshanks and Gilbert, 2008).

A key objective for future work is to develop measurement techniques for seeing through overlying dilute clouds of sediment, to determine whether dense near-bed layers are present. Future studies need to sample the deposits from monitored flows, and recent work has shown how repeated bathymetric surveys are powerful tool for understand submarine flows. Finally, a source-to-sink approach is needed to document the evolving character of submarine flows along their flow path.

We hope that this contribution will encourage innovative future strategies for studying these fascinating (and sometimes frustrating) submarine flows.

\section{Acknowledgements}

We would like to thank those who have collected the data summarised here and have discussed their views of submarine flows. We would also like to thank Pere Puig, Bernard Dennilou and an anonymous journal reviewer for their comments. John Hughes Clarke, Philip Hill and Gwyn Lintern are thanked in particular for discussion of flow monitoring offshore from the Squamish and Fraser Rivers in Canada.

\section{References}

Arzola, R.G., Wynn, R.B., Lastras, G., Masson, D.G., Weaver, P.P.E., 2008. Sedimentary features and processes in the Nazare and Setubal submarine canyons, west Iberian Margin. Marine Geology 250, 64-88.

Atwater, B.F., Griggs, G.B., 2012. Deep-sea turbidites as guides to Holocene earthquake history at the Cascadia Subduction Zone - alternative views for a seismic-hazard workshop. U.S. Geological Survey Open-File Report, 2012-1043 (58 pp., http://pubs. usgs.gov/of/2012/1043/).

Ayranci, K., Lintern, D.G., Hill, P.R., 2012. Tide-supported gravity flows on the upper delta front, Fraser River delta, Canada. Marine Geology 326, 166-170.

Barley, B., 1999. Deepwater problems around the world. Leading Edge 18, 488-494.

Benjamin, T.B., 1968. Gravity currents and related phenomena. Journal of Fluid Mechanics 31, 209-248

Best, J.L., Kostaschuk, R.A., Peakall, J., Villard, P.V., Franklin, M., 2005. Whole flow field dynamics and velocity pulsing within natural sediment-laden underflows. Geology 33, 765-768.

Bird, L.E., Paull, C.K., Hobson, B.W., 2007. Instrumentation for investigating submarine canyons: the development of a self-triggering event detector to investigate sediment transport events. Sea Technology. 17-21 (August 2007)

Bornhold, B.D., Ren, P., Prior, D.B., 1994. High-frequency turbidity currents in British Colombia fjords. Geo-Marine Letters 14, 238-243.

Bouma, A.H., 1962. Sedimentology of Some Flysch Deposits: A Graphic Approach to Facies Interpretation.Elsevier, Amsterdam (168 pp.).

Bourcart, J., Glangeaud, L., 1956. Perturbations sous-marines et courants de turbidité résultant du tremblement de terre d'Orléansville. Comptes Rendus de l'Académie des Sciences de Paris 242, 1504-1506.

Bowen, A.J., Normark, W.R., Piper, D.J.W., 1984. Modelling of turbidity currents on Navy Submarine Fan, California Continental Borderland. Sedimentology 31, 169-185.

Brucker, S., Hughes Clarke, J.E., Beaudoin, J., Lessels, C., Czotter, K., Loschiavo, R., Iwanowska, K., Hill, P., 2007. United States Hydrographic Conference, Norfolk, Virginia (16 pp.).

Canals, M., Puig, P., de Madron, X.D., Heussner, S., Palanques, A., Fabres, J., 2006. Flushing submarine canyons. Nature 444, 354-357.

Canals, M., Danovaro, R., Heussner, S., Lykousis, V., Puig, P., Trincardi, F., Calafat, A., Durrieu de Madron, X., Palanques, A Sanchez-Vidal, A, 2009. Cascades in Mediterranean submarine grand canyons. Oceanography 22, 26-43.

Carter, L., Burnett, D., Drew, S., Hagadorn, L., Marle, G., Bartlett-McNeil, D., Irvine, N., 2009. Submarine cables and the oceans - connecting the world. UNEP-WCMC Biodiversity Series 31. ICPC/UNEP/UNEP-WCMC (64 pp.).

Carter, L., Milliman, J., Wynn, R.B., Gavey, R., Talling, P.J., Wu, C.-Y., Evans, G., Liu, C.-S., Su, C.-C., 2012. Typhoon flood and earthquakes form long distance sediment flows through the deep ocean off Taiwan. Geophysical Research Letters L12603. http:// dx.doi.org/10.1029/2012GL051172.

Cartigny, M.J.B., Postma, G., Van den Berg, J.H., Mastbergen, D.R., 2010. A comparative study of sediment waves and cyclic steps based on geometries, internal structures and numerical modelling. Marine Geology 280, 40-56.

Cattaneo, A., Babonneau, N., Dan, G., Déverchère, J., Domzig, A., Gaullier, V., Lepillier, B., de Lépinay, B.M., Nougués, A., Strzerzynski, P., Sultan, N., Yelles, K., 2010. Submarine landslides along the Algerian Margin: a review of their occurrence and potential link with tectonic structures. In: Mosher, D.C., Shipp, R.C., Moscardelli, L., Chaytor, J.D., Baxter, C.D.P., Lee, H.J., Urgeles, R. (Eds.), Submarine Mass Movements and Their Consequences. Advances in Natural and Technological Hazard Research, 28. Springer, London, pp. 541-552.
Cattaneo, A., Babonneau, N., Ratzov, G., Dan-Unterseh, D., Yelles, K., Bracene, R., Mercier de Lépinay, B., Boudiaf, A., Déverchère, J.D., 2012. Searching for the seafloor signature of the 21 May 2003 Boumerdes earthquake offshore central Algeria. Natural Hazards and Earth System Sciences 12, 2159-2172.

Chikita, K., 1989. A field study on turbidity currents initiated from spring runoffs. Water Resources Research 25, 257-271.

Chikita, K., 1990. Sedimentation by river induced turbidity currents - field measurements and interpretation. Sedimentology 37, 891-905.

Chikita, K., Okumura, Y., 1987. Dynamics of river-induced turbidity currents from field measurements. Geophysical Bulletin Hokkaido University 49, 291-300.

Chikita, K., Okumura, Y., 1990. Dynamics of turbidity currents measured in Katsurazawa Reservoir, Hokkaido, Japan. Journal of Hydrology 117, 323-338.

Christian, H.A., Woeller, D.J., Robertson, P.K., Courtney, R.C., 1997. Site investigation to evaluate flow liquefaction slides at Sand Heads. Fraser River delta. Geotechnical Journal 34, 384-397.

Conway, K.W., Barrie, J.V., Picard, K., Bornhold, B.D., 2012. Submarine channel evolution: active channels in fjords, British Columbia, Canada. Geo-Marine Letters 32, 301-312

Cooper, C., Wood, J., Andrieux, A., 2013. Turbidity current measurements in the Congo Canyon. OTC Abstract 23992. Offshore Technology Conference, 6-9 May, Houston, Texas 12 pp.

Coussot, P., 1997. Mudflow rheology and dynamics. IAHR Monograph.Balkema, Rotterdam (272 pp.).

Crookshanks, S., Gilbert, R., 2008. Continuous, diurnally fluctuating turbidity currents in Kluane Lake, Yukon Territory. Canadian Journal of Earth Sciences 45, 1123-1138.

Colantoni, P., Gennesseaux, M., Vanney, J.R., Ulzeca, A., Melegari, G., Trombetta, A., 1992 Processi dinamici del canyon sottomarino di Gioia Tauro (Mare Tirreno). Giornale di Geologia 54, 190-213.

Dan, G., Sultan, N., Savoye, B., 2007. The 1979 Nice harbour catastrophe revisited: trigge mechanism inferred from geotechnical measurements and numerical modelling. Marine Geology 245, 40-64.

De Cesare, G., Schleiss, A., Hermann, F., 2001. Impact of turbidity currents on reservoi sedimentation. Journal of Hydraulic Engineering 127, 6-16.

De Cesare, G., Boillat, J.L., Schleiss, A.J., 2006. Circulation in stratified lakes due to floodinduced turbidity currents. Journal of Environmental Engineering 132, 1508-1517.

de Stiger, H.C., Boer, W., de Jesus Mendes, P.A., Cesar Jesus, C., Thomsen, L., ven den Bergh, G.D., van Weering, T.C.E., 2007. Recent sediment transport and deposition in Nazaré Canyon, Portuguese continental margin. Marine Geology 246, 144-164.

Dengler, A.T., Wilde, P., Noda, E.K., Normark, W.R., 1984. Turbidity currents generated by Hurricane Iwa. Geo-Marine Letters 4, 5-11.

Dill, R.F., 1964. Sedimentation and erosion in Scripps Submarine Canyon Head. In: Miller R.L. (Ed.), Papers in Marine Geology, Shepard Commemorative Vol. pp. 23-41.

Dill, R.F., 1967. Effects of explosive loading on the strength of sea floor sand. In: Richards A.F. (Ed.), Marine Geotechnique. Univ. Illinois Press, Chicago, pp. 291-307.

Dill, R.F., 1969. Earthquake effects on fill of Scripps Submarine Canyon. Geological Society of America Bulletin 80, 321-328.

El-Robrini, M., Gennesseaux, M., Mauffret, A., 1985. Consequences of the El-Asnam earthquakes: turbidity currents and slumps on the Algerian margin (western Mediterranean). Geo-Marine Letters 5, 171-176.

Fan, J., Morris, G., 1992. Reservoir sedimentation. I: delta and density current deposits Journal of Hydraulic Engineering 118 (3), 354-369.

Feng, Z., Zhang, S., Cross, T.A., Feng, Z., Xie, X.F., Zhao, B., Fu, X., Wang, C., 2010. Lacustrine turbidite channels and fans in the Mesozoic Songliao Basin, China. Basin Research 22 96-107.

Fernandez, R.L., Imberger, J., 2008. Time-varying underflow into a continuous stratification with bottom slope. Journal of Hydraulic Engineering 134, 1191-1198.

Forel, F., 1885. Les ravins sous-lacustres des fleuves glaciares. Comptes Rendus de l'Académie des Sciences de Paris 101, 725-728.

Forel, F., 1895. Le Léman: monographie limnologique. Lausanne, Librairie de l'Université, Switzerland $651 \mathrm{pp}$

Freundt, A., Wilson, C.J.N., Carey, S.N., 2000. Ignimbrites and block-and-ash flow deposits. In: Sigurdsson, H. (Ed.), Encyclopedia of Volcanoes. Academic Press, London, pp. 581-599.

Galy, V., France-Lanord, C., Beyssac, O., Faure, P., Kudrass, H., Palhol, F., 2007. Efficient organic carbon burial in the Bengal fan sustained by the Himalayan erosional system. Nature 450, 407-410.

Garfield, N., Rago, T.A., Schnebele, K.J., Collins, C.A., 1994. Evidence of a turbidity curren in Monterey Submarine Canyon associated with the 1989 Loma Prieta earthquake. Continental Shelf Research 14, 673-686.

Gavey, R., 2012. An Evaluation of Modern Hyperpycnal Processes and Their Relevance to the Geological Record. (Unpublished PhD thesis) Univ. Southampton (322 pp.).

Gennesseaux, M., Mauffret, A., Pautot, G., 1980. Les glissements sous-marins de la pente continentale niçoise et la rupture des câbles en mer Ligure (Méditerranée occidentale). Comptes Rendus de l'Académie des Sciences de Paris 290, 959-962.

Gilbert, R., Crookshanks, S., Hodder, K., Spagnol, J., Stull, R., 2006. The record of an extreme flood in the sediments of montane Lake Lillooet, British Columbia: implications for paleo-environmental assessment. Journal of Paleolimnology 37, 737-745.

Gilbert, R., Crookshanks, S., 2009. Sediment waves in a modern high-energy glacilacustrine environment. Sedimentology 56, 645-659.

Girardclos, S., Schmidt, OT, Sturm, M. Ariztegui, D, Pugin, A, Anselmetti, F.S, 2007. The 1996 AD delta collapse and large turbidite in Lake Brienz. Marine Geology 241, 137-154.

Girardclos, S., Hilbe, M., Corella, J.P., Loizeau, J.-L., Kremer, K., Delsontro, T., Argantegui, A Moscariello, A., Arlaud, F., Akhtman, Y., Anselmetti, F.S., Lemmin, U., 2013. Searching the Rhone delta channel in Lake Geneva since François-Alphonse Forel. Archives des Sciences (in press).

Goldfinger, C., Morey, A.E., Nelson, C.H., Gutierrez-Pastor, J., Johnson, J.E., Karabanov, E., Chaytor, J., Ericcson, A., 2007. Rupture lengths and temporal history of 
significant earthquakes on the offshore and north coast segments of the Northern San Andreas Fault based on turbidite stratigraphy. Earth and Planetary Science Letters 254, 9-27.

Gorsline, D.S., 1996. Depositional events in Santa Monica Basin, California Borderland, over the past five centuries. Sedimentary Geology 104, 73-88.

Gould, H.R., 1960. Turbidity currents. U.S. Geol. Soc. Prof. Paper, 295, pp. 201-207.

Guerrero, M., Ruther, N., Szupiany, R.N., 2012. Laboratory validation of acoustic Doppler current profiler (ADCP) techniques for suspended sediment investigations. Flow Measurement and Instrumentation 23, 40-48.

Hale, P.R., Nittrouer, C.A., Liu, J.T., Keil, R.G., Ogston, O.S., 2012. Effects of a major typhoon on sediment accumulation in Fangliao Submarine Canyon, SW Taiwan. Marine Geology. http://dx.doi.org/10.1016/j.margeo.2012.07.008

Hart, B.S., Prior, D.B., Barrie, J.V., Currie, R.G., Luternauer, J.L., 1992. A river mouth submarine channel and failure complex, Fraser Delta, Canada. Sedimentary Geology $81,73-87$.

Hart, B.S., Hamilton, T.S., Vaughn Barrie, J., 1998. Sedimentation rates and patterns on a deep-water delta (Fraser Delta, Canada): integration of high-resolution seismic stratigraphy, core lithofacies, and ${ }^{137} \mathrm{Cs}$ fallout stratigraphy. Journal of Sedimentary Research 68, 556-568.

Haughton, P.D.W., Davis, C., McCaffrey, W., Barker, S.P., 2009. Hybrid sediment gravity flow deposits - classification, origin and significance. In: Amy, L.A., McCaffrey, W.B. Talling, P.J. (Eds.), Hybrid and Transitional Submarine Flows. Marine Petrol. Geol, 26, pp. 1900-1918.

Hay, A.E., Burling, E.W., Murray, J.W., 1982. Remote acoustic detection of a turbidity current surge. Science 217, 833-845.

Hay, A.E., 1987a. Turbidity currents and submarine channel formation in Rupert Inlet, British Colombia: 1. Surge observations. Journal of Geophysical Research 92, 2875-2881.

Hay, A.E., 1987b. Turbidity current and submarine channel formation in Rupert Inlet British Colombia: 2. The roles of continuous and surge-type flow. Journal of Geophysical Research 92, 2883-2900

Heezen, B.C., Ewing, M., 1952. Turbidity currents and submarine slumps, and the 1929 Grand Banks earthquake. American Journal of Science 250, 849-873.

Heezen, B.C., Hollister, C.D., 1971. The Face of the Deep.Oxford Univ. Press, New York (659 pp.).

Heezen, B.C., Ericson, D.B., Ewing, M., 1954. Further evidence for a turbidity current following the 1929 Grand Banks earthquake. Deep-Sea Research 1, 193-202.

Heezen, B.C., Ewing, M., 1955. Orléansville earthquake and turbidity currents. AAPC Bulletin 39, 2505-2514.

Heezen, B.C., Menzies, R.J., Schneider, E.D., Ewing, W.M., Granelli, N.C.L., 1964. Congo submarine canyon. AAPG Bulletin 48, 1126-1149.

Heezen, B.C., Ewing, M., Johnson, G.L., 1966. The Gulf of Corinth floor. Deep-Sea Research 13, 381-401.

Hill, P., 2012. Changes in submarine channel morphology and slope sedimentation patterns from repeat multibeam surveys in the Fraser River delta, western Canada. nternational Association of Sedimentologists. Special Publication 44, 47-70.

Hsu, S.K., Kuo, J., Lo, C.L., Tsai, C.H., Doo, W.B., Ku, C.Y., Sibuet, J.C., 2008. Turbidity currents, submarine landslides and the 2006 Pingtung earthquake off SW Taiwan. Terrestrial, Atmospheric and Oceanic Sciences 19, 767-772.

Hu, P., Cao, Z., Pender, G., Tan, G., 2012. Numerical modelling of turbidity currents in the Xiaolangdi revservoir, Yellow River, China. Journal of Hydrology 464-465 (41), 53.

Hughes Clarke, J.E., 1988. The Geological Record of the 1929 Grand Banks Earthquake and Its Relevance to Deep-sea Clastic Sedimentation. (PhD thesis) Dalhousie University, Halifax, Nova Scotia.

Hughes Clarke, J.E., Shor, A.N., Piper, D.J.W., Mayer, L.A., 1990. Large-scale current-induced erosion and deposition in the path of the 1929 Grand Banks turbidity current Sedimentology 37, 613-629.

Hughes Clarke, J.E., Brucker, S., Hill, P., Conway, K., 2009. Monitoring morphological evolution of fjord deltas in temperate and Arctic regions. In: Chiocci, F.L., Ridente, D. Casalbore, D. Bosman, A. (Eds.) International Conference on Seafloor Mapping for Geohazard Assessment. Rendiconti online della Society Geologica Italiana, 7 , pp. 147-150.

Hughes Clarke, JE Brucker, S, Muggah, J Church, I, Cartwright, D, Kuus, P, Hamilton, T, Pratomo, D., Eisan, B., 2012. The Squamish Pro Delta: Monitoring Active Landslides and Turbidity Currents: Canadian Hydrographic Conference 2012. Proceedings. 15 pp

Hughes Clarke, J.E., Videra Marques, C.R., Pratomo, D., Hughes Clarke, J.E., Videra Marques, C.R., Pratomo, D., 2013. Imaging active mass wasting on a fjord delta, Squamish, British Columbia. Submarine Mass Movements and their Conseques, V (in press).

Hunt, J.E., Wynn, R.B., Masson, D.G., Talling, P.J., Teagle, D.A., 2011. Sedimentological and geochemical evidence for multistage failure of volcanic island landslides: a case study from Icod landslide on north Tenerife, Canary Islands. G-cubed. http:// dx.doi.org/10.1029/2011GC003740.

Hurther, D., Thorne, P.D., Bricault, M., Lemmin, U., Barnoud, J.-M., 2011. A multi-frequency acoustic concentration and velocity profiler (ACVP) for boundary layer measurements of fine-scale flow and sediment transport processes. Coastal Engineering 58, 594-605.

Hurzeler, B.E., Imberger, J., Ivey, 1996. Dynamics of turbidity current with reversing buoyancy. Journal of Hydraulic Engineering 122, 230-236.

Iatrou, M., Ferentinos, G., Papatheodorou, G., Piper, D.J.W., Tripsanas, E., 2007. Anthropogenic turbidity current deposits in a seismically active graben, the Gulf of Corinth, Greece: a useful tool for studying turbidity current transport processes, In: Lykousis, V., Sakellariou, D., Locat, J. (Eds.), Submarine Mass Movements and Their Consequences. 3rd International Symposium, pp. 149-157.

Ikehara, K., Ashi, J., Machiyama, H., Shirai, M., 2012. Submarine slope response to earthquake shaking within West Sagami Bay, Central Japan. In: Yamada, Y., Kawamura,
K., Ikehara, K., Ogawa, Y., Urgeles, R., Mosher, D., Chaytor, J., Strasser, M. (Eds.), Submarine Mass Movements and Their Consequences. Advances in Natural and technological Hazards Research, 31. Springer, Dordrecht. http://dx.doi.org/10.1007/ 978-94-007-2162-3 48

Inman, D.L., Nordstrom, C.E., Reinhard, E.F., 1976. Currents in submarine canyons: an airsea-land interaction. Annual Review of Fluid Mechanics 8, 275-310.

Iverson, N.R., Hooyer, T.S., Fischer, U.H., Cohen, D., Moore, P.L., Jackson, M., Lappegard, G., Kohler, J., 2007. Soft-bed experiments beneath Engabreen, Norway: regelation infiltration, basal slip, and bed deformation. Journal of Glaciology 53, 323-341.

Iverson, R.M., 1997. The physics of debris flows. Reviews of Geophysics 35, 245-296.

Iverson, R.M., Logan, M., LaHusen, R.G., Berti, M., 2010. The perfect debris flow? Aggregated results from 28 large-scale experiments. Journal of Geophysical Research 115, F03005 (Art. No.).

Johnson, K.S., Paull, C.K., Barry, J.P., Chavez, F.P., 2001. A decadal record of underflows from a coastal river into the deep sea. Geology 29, 1019-1022.

Kao, S.J., Dai, M., Selvaraj, K., Zhai, W., Cai, P., Chen, S.N., Yang, J.Y.T., Liu, J.T., Liu, C.C., Syvitski, J.P.M., 2010. Cyclone driven deep sea injection of freshwater and heat by hyperpycnal flow in the subtropics. Geophysical Research Letters 37, L21702. http://dx.doi.org/10.1029/2010GL044893.

Komar, P.O., 1969. The channelized flow of turbidity currents with application to Monterey deep-sea fan channel. Journal of Geophysical Research 74, 4544-4558.

Komar, P.D. 1977. Computer simulation of turbidity current flow and the study of deepsea channels and fan sedimentation. In: Golderg, E.D., McCave, N., O'Brien, J.J., Steele, J.H. (Eds.), The Sea, vol. 6. John Wiley and Sons, New York, pp. 603-621.

Komar, P.O., 1985. The hydraulic interpretation of turbidites currents: field measurements and interpretation from their grain sizes and sedimentary structures. Sedimentology 37, 891-905

Kostaschuk, R., Best, J., Villard, P., Peakall, J., Franklin, M., 2005. Measuring flow velocity and sediment transport with an acoustic Doppler current profiler. Geomorphology $68,25-37$.

Khripounoff, A., Vangriesheim, A., Babonneau, N., Crassous, P., Dennielou, B., Savoye, B., 2003. Direct observation of intense turbidity current activity in the Zaire submarine valley at $4000 \mathrm{~m}$ water depth. Marine Geology 194, 151-158.

Khripounoff, A., Vangriesheim, A., Crassous, P., Etoubleau, J., 2009. High frequency of sediment gravity flow events in the Var submarine canyon (Mediterranean Sea). Marine Geology 263, 1-6.

Khripounoff, A., Crassous, P., Lo Bue, N., Dennielou, B., Silva Jacinto, R., 2012. Different types of sedimenmt gravity flows detercted in the Var submarine canyon (northwestern Mediterranean Sea). Progress in Oceanography 106, 138-153.

Kostaschuk, R.A., Stephan, B.A., Lutenauer, J.L., 1989. Bedforms, bed material, and bed-load transsport in a salt-wedge estuary: Fraser River, British Columbia. Canadian Journal of Earth Sciences 26, 1440-1452.

Kostaschuk, R.A., Luternauer, J.L., McKenna, G.T., Moslow, T.F., 1992. Sediment transport in a submarine channel system: Fraser River Delta, Canada. Journal of Sedimentary Research 62, 273-282.

Kremer, K., Simpson, G., Girardclos, S., 2012. Giant Lake Geneva tsunami in AD 563. Nature Geoscience 5 (11), 756-757.

Kuenen, P.H., 1952. Estimated size of the Grand Banks turbidity current. American Journal of Science 250, 874-884.

Le Friant, A., Deplus, C., Boudon, G., Komorowski, J.-C., Trofimovs, J., Sparks, R.S.J., Talling, P.J., 2009. Submarine deposition of volcaniclastic material from the 1995-2005 eruptions of the Soufriere Hills volcano, Montserrat. Journal of the Geological Society of London 166, 171-182.

Le Friant, A., Deplus, C., Boudon, G., Feuillet, N., Trofimovs, J., Komorowski, J.-C., Sparks, R.S.J., Talling, P.J., Loughlin, S., Palmer, M., Ryan, G., 2010. The eruption of Soufrière Hills (1995-2009) from an offshore perspective: insights from repeated swath bathymetry surveys. Geophysical Research Letters 37, L11307. http://dx.doi.org/ 10.1029/2010GL043580.

Lambert, A., 1982. Tröbeströme des Rheins am Grunde des Bodensees. Wasserswirtschaft, Germany 72 (4) (in German).

Lambert, A., Hsu, K.J., 1979. Non-annual cycles of varve-like sedimentation in Walensee, Switzerland. Sedimentology 26, 453-461.

Lambert, A., Giovanoli, F., 1988. Records of riverborne turbidity currents and indications of slope failures in the Rhone Delta of Lake Geneva. Limnology and Oceanography 33, $458-468$

Levine, A.H., Kieffer, S.W., 1991. Hydraulics of the August 7, 1980, pyroclastic flow at Mount-St-Helens, Washington. Geology 19, 1121-1124.

Lintern, G., Hill, P., 2010. An underwater laboratory at the Fraser River Delta. Eos, Transactions of the American Geophysical Union 91, 38

Liu, J.T., Lin, H.-L., Huang, J.J., 2006. A submarine canyon conduit under typhoon conditions off Southern Taiwan. Deep-Sea Research Part I 53, 223-240.

Liu, J.T., Wang, Y.-H., Yang, R.T., Hsu, R.T., Kao, S.-J., Lin, H.-L., Kuo, F.H., 2012. Cyclone induced hyperpycnal turbidity currents in a submarine canyon. Journal of Geophysical Research 117, C04033. http://dx.doi.org/10.1029/2011JC007630.

Liu, J.T., Wang, Y.H., Lee, I.-H., Hsu, R.T., 2010. Quantifying tidal signatures of the benthic nepheloid layer in Gaoping Submarine Canyon in Southern Taiwan. Marine Geology 271, 119-130.

Lowe, D.R., 1976. Subaqueous liquefied and fluidised sediment flows and their deposits. Sedimentology 23, 285-308.

Lowe, D.R., 1982. Sediment gravity flows. 2. Depositional models with special reference to high density turbidity currents. Journal of Sedimentary Petrology 52, 279-298.

McClung, D., Shaerer, P., 2006. The Avalanche Handbook.Mountaineers Books, Seattle (288 pp.).

Marshall, N.F., 1978. Large storm-induced sediment slump reopens an unknown Scripps Submarine Canyon tributary. In: Stanley, D.J., Kelling, G. (Eds.), Sedimentation in Submarine Canyons, Fans and Trenches. Dowden, Hutchinson and Ross, Inc., Pennsylvania, pp. 73-82. 
Marti, C.L., Mills, R., Imberger, J., 2011. Pathways of multiple inflows into a stratified reservoir: Thomson Reservoir, Australia. Advances in Water Resources 34, 551-561.

Martin, J., Palanques, A., Vitorino, J., Oliviera, A., de Stiger, H.C., 2011. Near-bottom particulate matter dynamics in the Nazaré submarine canyon under calm and stormy conditions. Deep-Sea Research Part II 58, 2388-2400.

Mas, V., Mulder, T., Dennielou, B., Schmidt, S., Khripounoff, A., Savoye, B., 2010. Multiscale spatio-temporal variability of sedimentary deposits in the Var turbidite system (North-Western Mediterranean Sea). Marine Geology 275, 37-52.

Masson, D.G., Huvenne, V.A.I., de Stiger, H.C., Wolff, G.A., Kirjakoulakis, K., Arzola, R.G., Blackbird, S., 2010. Efficient burial of carbon in a submarine canyon. Geology 38, 831-834.

Mastbergen, D.R., van den Berg, J.H., 2003. Breaching in fine sand and the generation of sustained turbidity currents in submarine canyons. Sedimentology 50, 625-637.

Middleton, G.V., 1966. Experiments on density and turbidity currents: II. Uniform flow of density currents. Canadian Journal of Earth Sciences 3, 627-637.

Mikada, H., Mitsuzawa, K., Matsumoto, H., Watanabe, T., Morita, S., Otsuka, R., Sugioka, H., Baba, T., Araki, E., Suyehiro, K., 2006. New discoveries in dynamics of a M8 earthquake-phenomena and their implications from the 2003 Tokachi-oki earthquake using a long term monitoring cabled observatory. Tectonophysics 426, 95-105.

Monecke, K., Anselmetti, F.S., Becker, A., Sturm, M., Giardini, D., 2004. The record of historic earthquakes in lake sediments of Central Switzerland. Tectonophysics 394, 21-40.

Mosher, D.C., Piper, D.J.W., 2007. Analysis of multibeam seafloor imagery of the Laurentian Fan and the 1929 Grand Banks landslide area. In: Lykousis, V., Sakellariou, D., Locat, J. (Eds.), Submarine Mass Movements and Their Consequences, 3rd International Symposium, pp. 77-88.

Mulder, T., Savoye, B., Syvitski, J.P.M., 1997. Numerical modelling of a mid-sized gravity flow: the 1979 Nice turbidity current (dynamics, processes, sediment budget and seafloor impact). Sedimentology 44, 305-326.

Mulder, T., Zaragosi, S., Jouanneau, J.-M., Bellaiche, G., Guérinaud, S., Querneau, J., 2009. Deposits related to the failure of the Malpasset Dam in 1959: an analogue for hyperpycnal deposits from jokulhlaups. Marine Geology 260, 81-89.

Mullenbach, B.L., Nittrouer, C.A., Puig, P., Orange, D.L., 2004. Sediment deposition in a modern submarine canyon: Eel Canyon, northern California. Marine Geology 211, 101-119.

Nielsen, T., Shew, R.D., Steffens, G.S., Studlick, J.R.J., 2007. Atlas of deepwater outcrops. AAPG Studies in Geology, 56. Shell Exploration and Production and American Association of Petroleum Geologists (504 pp.).

Normark, W.R., 1989. Observed parameters for turbidity current flow in channels, reserve fan, Lake Superior. Journal of Sedimentary Petrology 59, 423-431.

Normark, W.R., Dickson, F.H., 1976a. Sublacustrine fan morphology in Lake Superior. AAPG Bulletin 60, 1021-1036.

Normark, W.R., Dickson, F.H., 1976b. Man made turbidity currents in Lake Superior. Sedimentology 23, 815-831.

Nougués, A., Sultan, N., Cattaneo, A., Dan, G., Yelles, K., PRISME team, 2010. Detailed analysis of a submarine landslide (SAR-27) in the deep basin offshore Algiers (Western Mediterranean). In: Mosher, D.C., Shipp, R.C., Moscardelli, L., Chaytor, J.D., Baxter, C.D.P., Lee, H.J., Urgeles, R. (Eds.), Submarine Mass Movements and Their Consequences. Advances in Natural and Technological Hazard Research, 28. Springer, London, pp. 541-552.

Ogston, A.S., Cacchione, D.A., Sternberg, R.W., Kinecke, G.C., 2000. Observations of storm and river flood-driven sediment transport on the northern California continental shelf. Continental Shelf Research 20, 2141-2162.

Palanques, A., Martin, J., Puig, J., Guillen, J., Company, J.B., Sardia, F., 2006. Evidence of sediment gravity flows induced by trawling in the Palamos (Fonera) submarine canyon (northwestern Mediterranean). Deep-Sea Research Part I 53, 201-214.

Palanques, A., Puig, P., Latasa, M., Sharek, R., 2009. Deep sediment transport induced by storms and dense shelf water cascading in the northwestern Mediterranean. Deep-Sea Research Part I 56, 425-434.

Parker, G., 1982. Conditions for the ignition of catastrophically erosive turbidity currents. Marine Geology 46, 307-327.

Parsons, D.R., Peakall, J., Aksu, A.E., Flood, R.D., Hiscott, R.N., Besiktepe, S., Mouland, D., 2010. Gravity-driven flow in a submarine channel bend: direct field evidence of helical flow reversal. Geology 38, 1063-1066.

Pasqual, C., Sanchez-Vidal, A., Zuniga, D., Calafat, A., Canals, M., Durrieu de Madron, X., Puig, P., Heussner, S., Palanques, A., Delsaut, N., 2010. Flux and composition of settling particles across the continental margin of the Gulf of Lion: the role of dense shelf water cascading. Biogeosciences 7, 217-231.

Paull, C.K., Stratton, S., Conway, M., Brekke, K., Dawe, T.C., Maher, N., Ussler, W., 2001. Deep sea vibracoring system improves ROV sampling capabilities. Eos, Transactions of the American Geophysical Union 82, 325-326.

Paull, C.K., Ussler III, W., Greene, H.G., Keaten, R., Mitts, P., Barry, J., 2003. Caught in the act: the 20 December 2001 gravity flow event in Monterey Canyon. Geo-Marine Letters 22, 227-232.

Paull, C.K., Mitts, P., Ussler III, W., Keaten, R., Greene, H.G., 2005. Trail of sand in upper Monterey Canyon. GSA Bulletin 117, 1134-1145.

Paull, C.K., Ussler III, W., Caress, D.W., Lundsten, E., Barry, J., Covault, J.A., Maier, K.L., Xu, J., Augenstein, S., 2010a. Origins of large crescent-shaped bedforms within the axial channel of Monterey Canyon. Geosphere 6, 755-774.

Paull, C.K., Schlining, B., Ussler, W.I.I.I., Lundsten, E., Barry, J.P., Caress, D.W., Johnson, J.E., McGann, M., 2010b. Submarine mass transport within Monterey Canyon: benthic disturbance controls on the distribution of chemosynthetic biological communities. In: Mosher, D.C., Shipp, R.C., Moscardelli, L., Chaytor, J.D., Baxter, C.D.P., Lee, H.J., Urgeles, R. (Eds.), Submarine Mass Movements and Their Consequences, Advances in Natural and Technological Hazard Research, Springer, London. 4th International Symposium on Submarine Mass Movements and Their Consequences, 28. Springer, London, pp. 229-247.
Paull, C.K., Caress, D.W., Ussler III, W., Lundsten, E., Meiner-Johnson, M., 2011. High resolution bathymetry of the axial channels within Monterey and Sequel submarine canyons offshore central California. Geosphere 7, 1077-1101. http://dx.doi.org/ 10.1130/GES00636.1.

Paull, C.K., Caress, D.W., Lundsten, E., Gwiazda, R., Anderson, K., McGann, M., Conrad, J. Edwards, B., Sumner, E.J., 2012. Anatomy of the La Jolla submarine canyon system: offshore southern California. Marine Geology. http://dx.doi.org/10.1016/j.margeo2012. 10.003 .

Pharo, C.H., Carmack, E.C., 1979. Sedimentation processes in a short residence-time intermontane lake, Kamloops Lake, British Colombia. Sedimentology 26, 523-541.

Piper, D.J.W., 1970. Transport and deposition of Holocene sediment on La-Jolla Deep Sea Fan, California. Marine Geology 8, 211-226.

Piper, D.J.W., Aksu, A.E., 1987. The source and origin of the 1929 Grand Banks turbidity current inferred from sediment budgets. Geo-Marine Letters 7, 177-182.

Piper, D.J.W., Normark, W.R., 2009. Processes that initiate turbidity currents and their influence on turbidites: a marine geology perspective. Journal of Sedimentary Research 79, 347-362.

Piper, D.J.W., Shor, A.N., Farre, J.A., O'Connell, S., Jacobi, R., 1985. Sediment slides and turbidity currents on the Laurentian Fan: sidescan sonar investigations near the epicenter of the 1929 Grand Banks earthquake. Geology 13, 538-541.

Piper, D.J.W., Shor, A.N., Hughes Clarke, J.E., 1988. The 1929 Grand Banks earthquake, slump, and turbidity current. G.S.A. Special Paper, 229, pp. 77-92.

Piper, D.J.W., Savoye, B., 1993. Processes of Late Quaternary turbidity-current flow and deposition on the Var deep-sea fan, North-west Mediterranean Sea. Sedimentology 40, 557-582.

Piper, D.J.W., Cochonat, P., Morrison, M., 1999. The sequence of events around the epicentre of the 1929 Grand Banks earthquake: initiation of debris flows and turbidity currents inferred from sidescan sonar. Sedimentology 46, 79-97.

Piper, D.J.W., Shaw, J., Skene, K.I., 2007. Stratigraphic and sedimentological evidence for late Wisconsinan sub-glacial outburst floods to Laurentian Fan. Palaeogeography, Palaeoclimatology, Palaeoecology 246, 101-119.

Prior, D.B., Bornhold, B.D., 1989. Submarine sedimentation on a developing Holocene fan delta. Sedimentology 36, 1053-1076.

Prior, D.B., Bornhold, B.D., Wiseman Jr., W.J., Lowe, D.R., 1987. Turbidity current activity in a British Columbia fjord. Science 237, 1330-1333.

Puig, P., Ogston, A.S., Mullenbach, B.L., Nittrouer, C.A., Sternberg, R.W., 2003. Shelf-to-canyon sediment transport processes on the Eel continental margin (northern California). Marine Geology 193, 129-149.

Puig, P., Ogston, A.S., Mullenbach, B.L., Nittrouer, C.A., Parsons, J.D., Sternberg, R.W., 2004 Storm-induced sediment gravity flows at the head of the Eel submarine canyon, northern California margin. Journal of Geophysical Research 109, C03019 (art. No.).

Puig, P., Palanques, A., Orange, D.L., Lastras, G., Canals, M., 2008. Dense shelf water cascades and sedimentary furrow formation in the Cap de Creus Canyon, northwestern Mediterranean Sea. Continental Shelf Research 28, 2017-2030.

Puig, P., Canals, M., Company, J.B., Martin, J., Amblas, D., Lastras, G., Palanques, A., Calafat A., 2012. Ploughing the deep sea floor. Nature 489, 286-289.

Ren, P., Bornhold, B.D., Prior, D.B., 1996. Seafloor morphology and sedimentary processes, Knight Inlet, British Colombia. Sedimentary Geology 103, 201-228.

Romero-Otero, G.A., Slatt, R.M., Pirmez, C., 2010. Detached and shelf-attached mass transport complexes on the Magdelena deepwater fan. In: Mosher, D.C., Shipp, R.C., Moscardelli, L, Chaytor, J.D., Baxter, C.D.P., Lee, H.J., Urgeles, R. (Eds.), Submarine Mass Movements and Their Consequences, Advances in Natural and Technological Hazard Research, Springer, London. 4th International Symposium on Submarine Mass Movements and Their Consequences, 28. Springer, London, pp. 593-606.

Rothé, J.-P., 1955. Le tremblement de terre d'Orléansville et la séismicité de l'Algérie, Revue des sciences et de leurs applications aux arts et à l'industrie. Nature 3237 $1-9$.

Sequeiros, O.E., Spinewine, B., Beaubouef, R.T., Garcia, M.H., Parker, G., 2010. Characteristics of velocity and excess density profiles of saline underflows and turbidity currents flowing over a mobile bed. Journal of Hydraulic Engineering 136, 412-434.

Shepard, F.P., Dill, R.F., 1966. Submarine Canyons and Other Sea Valleys.Rand McNally \& Company, U.S.A. (381 pp.).

Shepard, F.P., Dill, R.F., Von Rad, U., 1969. Physiography and sedimentary processes of La Jolla Submarine Fan and Fan-Valley, California. AAPG Bulletin 53, 390-420.

Shepard, F.P., McLoughlin, P.A., Marshall, N.F., Sullivan, G.G., 1977. Current-meter recordings of low-speed turbidity currents. Geology 5, 297-301.

Shor, A.N., Piper, D.J.W., Hughes Clarke, J.E., Mayer, L., 1990. Giant flute-like scour and other erosional features formed by the 1929 Grand Banks turbidity current. Sedimentology 37, 631-645.

Smith, D.P., Ruiz, G., Kvitek, R., Iampietro, P.J., 2005. Semi-annual patterns of erosion and deposition in Upper Monterey Canyon from serial multibeam bathymetry. GSA Bulletin 117, 1123-1133.

Smith, D.P., Kvitek, R., Ruiz, G., lampietro, P.J., Wong, K., 2007. Twenty-nine months of geomorphic change in upper Monterey Canyon (2002-2005). Marine Geology 236, 79-94.

Sommerfield, C.K., Nittrouer, C.A., 1999. Modern accumulation rates and a sediment budget for the Eel Shelf: a flood-dominated depositional environment. Marine Geology 154 (1-4), 227-241.

Sovilla, B., Schaer, M., Kern, M., Bartelt, P., 2008. Impact pressures and flow regimes in dense snow avalanches observed at the Vallee de la Sionne test site. Journal of Geophysical Research 113, F01010.

Sparks, R.S.J., Bonnecaze, R.T., Huppert, H.E., Lister, J.R., Hallworth, M.A., Mader, H., Phillips, J., 1993. Sediment-laden gravity currents with reversing buoyancy. Earth and Planetary Science Letters 114, 243-257.

Sternberg, R.W., Cacchione, D.A., Paulson, B., Kineke, G.C., Drake, D.E., 1996. Observations of sediment transport on the Amazon subaqueous delta. Continental Shelf Research $16,697-715$. 
Stow, D.A.V., Bowen, A.J., 1980. A physical model for the transport and sorting of finegrained sediment by turbidity currents. Sedimentology 27, 31-46.

Strasser, M., Hilbe, M., Anselmetti, F.S., 2011. Mapping basin-wide subaquatic slope failure susceptibility as a tool to assess regional seismic and tsunami hazards. Marine Geophysical Researches 32, 331-347.

Sumner, E.J., Talling, P.J., Amy, L.A., 2009. The deposits of flows transitional between turbidity currents and debris flow. Geology 37, 991-994.

Sumner, E.J., Siti, M.I., McNeill, L.C., Talling, P.J., Wynn, R.B., Henstock, T.J., Djajadihardja, Permana, H., 2013. Can turbidites be used to reconstruct a paleoearthquake record for the Sumatran Margin. Geology 41, 763-766.

Sun, T., Parker, G., 2005. Transportational cyclic steps created by flow over an erodible bed. Part 2. Theory and numerical simulation. Journal of Hydraulic Research 43 , 502-514.

Syvitski, J.P.M., Hein, F.J., 1991. Sedimentology of an arctic basin: Itirbilung Fiord, Baffin Island, Canada. Geological Survey of Canada Professional Paper 91-11 (67 pp.).

Talling, P.J., Amy, L.A., Wynn, R.B., Peakall, J., Robinson, M., 2004. Beds comprising debrite sandwiched within co-genetic turbidite: origin and widespread occurrence in distal depositional environments. Sedimentology 51 (1), 163-194.

Talling, J.F., 1966. The annual cycle of stratification and phytoplankton growth in Lake Victoria (east Africa). Internationale Revue der Gesamten Hydrobiologie 51, 545-621.

Talling, P.J., Wynn, R.B., Masson, D.G., Frenz, M., Cronin, B.T., Schiebel, R., Akhmetzhanov, A.M., Dallmeier-Tiessen, S., Benetti, S., Weaver, P.P.E., Georgiopoulou, A., Zühlsdorff, C., Amy, L.A., 2007a. Onset of submarine debris flow deposition far from original giant landslide. Nature 450, 541-544.

Talling, P.J., Amy, L.A., Wynn, R.B., Blackbourn, G., Gibson, O., 2007b. Turbidity current evolution deduced from extensive thin turbidites: Marnoso Arenacea Formation (Miocene), Italian Apennines. Journal of Sedimentary Research 77, 172-196.

Talling, P.J., Masson, D.G., Sumner, E.J., Malgesini, G., 2012a. Subaqueous sediment density flows: depositional processes and deposit types. Sedimentology. http://dx.doi.org/ 10.1111/j.1365-3091.2012.01353.x.

Talling, P.J., Malgesini, G., Felletti, F., 2012b. Can liquefied submarine debris flows deposit clean sandstone over large areas? Field evidence from the Marnoso-Arenacea Formation, Italian Apennines. Sedimentology (in press).

Taki, K., Parker, G., 2005. Transportational cyclic steps created by flow over an erodible bed. Part 1. Experiments. Journal of Hydraulic Research 43, 488-501.

Thunnell, R., Tappa, E., Varela, R., Llano, M., Astor, Y., Muller-Karger, F., Bohrer, R., 1999. Increased marine sediment suspension and fluxes following an earthquake. Nature 398, 233-236.

Traykovski, P., Geyer, W.R., Irish, J.D., Lynch, J.F., 2000. The role of wave-induced densitydriven fluid mud flows for cross-shelf transport on the Eel River continental shelf. Continental Shelf Research 20, 2113-2140.

Traykovski, P., Wiberg, P.L., Geyer, W.R., 2007. Observations and modelling of wavesupported sediment gravity flows on the Po prodelta and comparison to prior observations from the eel shelf. Continental Shelf Research 27, 375-399.

Trofimovs, J., Amy, L., Boudon, G., Deplus, C., Doyle, E., Fournier, N., Hart, M.B., Komorowski, J.C., Le Friant, A., Lock, E.J., Pudsey, C., Ryan, G., Sparks, R.S.J., Talling, P.J., 2006. Submarine pyroclastic deposits formed at the Soufriere Hills volcano, Montserrat (1995-2003): what happens when pyroclastic flows enter the ocean? Geology 34, 549-552.

Trofimovs, J., Sparks, R.S.J., Talling, P.J., 2008. Anatomy of a submarine pyroclastic flow and associated turbidity current: July 2003 dome collapse event, Soufrière Hills volcano, Montserrat, West Indies. Sedimentology 55, 617-634.

Tsutsui, B., Campbell, J.F., Coulbourn, W.T., 1987. Storm-generated, episodic sediment movements off Kahe Point, Oahu, Hawaii. Marine Geology 76, 281-299.

Umeda, M., Yokoyama, K., Ishiwara, T., 2000. A numerical simulation of turbidity currents and sedimentation in the Shichikashuku reservoir. Journal of Hydroscience and Hydraulic Engineering 18, 153-163.

Umeda, M., Yokoyama, K., Ishikawa, T., 2006. Observation and simulation of floodwater intrusion and sedimentation in the Shichikashuku Reservoir. Journal of Hydraulic Engineering 132, 881-891.

Underwood, M.B., 1991. Submarine canyons, unconfined turbidity currents, and sedimentary bypassing of fore-arc regions. Reviews in Aquatic Sciences 4, 149-200.

Van Tassell, J., 1981. Silver Abyssal Plain carbonate turbidite: flow characteristics. Journal of Geology 89, 317-333.

Vangriesheim, A., Khripounoff, A., Crassous, P., 2009. Turbidity events observed in situ along the Congo submarine channel. Deep-Sea Research Part II 56, 2208-2222.

Weber, M.E., Weidicke, M.H., Kudrass, H.R., Hubscher, C., Eelenkeuser, H., 1997. Active growth of the Bengal Fan during sea-level rise and highstand. Geology 25, 315-318.

Wei, T., Peakall, J., Parsons, D.R., Chen, Z., Zhao, B., Best, J., 2013. Three-dimensional gravity-current flow within a subaqueous bend: spatial evolution and force balance variations. Sedimentology. http://dx.doi.org/10.1111/sed.12052.
Weirich, F.H., 1984. Turbidity currents: monitoring their occurrence and movement with a three-dimensional sensor network. Science 224, 384-387.

Weirich, F.H., 1986a. The record of density-induced underflows in a glacial lake. Sedimentology 33, 261.

Weirich, F.H., 1986b. A study of the nature and incidence of density currents in a shallow glacial lake. Annals of the Association of American Geographers 76, 396.

Wheatcroft, R.W., Borgeld, J.C., 2000. Oceanic flood deposits on the northern California shelf: large-scale distribution and small scale physical properties. Continental Shelf Research 20, 2163-2190.

Winterwerp, J.C., Bakker, W.T., Mastbergen, D.R., van Rossum, H., 1992. Hyperconcentrated sand-water mixture flows over erodible bed. Journal of Hydraulic Engineering 118, $1508-1525$

Wright, L.D., Friedrichs, C.T., Kim, S.C., Scully, M.E., 2001. Effects of ambient currents and waves on gravity-driven sediment transport on continental shelves. Marine Geology $175,25-45$.

Wright, C.T., Friedrichs, C.T., 2006. Gravity-driven sediment transport on continental shelves: a status report. Continental Shelf Research 26, 2092-2107.

Wynn, R.B., Masson, D.G., 2003. Canary Islands landslides and tsunami generation: can we use turbidite deposits to interpret landslides processes? Submarine Mass Movement and Their Consequences. Advances in Natural and Technological Hazards Research, 19 , pp. 325-332.

Xu, J.P., Noble, M.A., 2009. Currents in Monterey Submarine Canyon. Journal of Geophysical Research 114, C03004. http://dx.doi.org/10.1029/2008JC004992.

Xu, J.P., Noble, M.A., Rosenfeld, L.K., 2004. In-situ measurements of velocity structure within turbidity currents. Geophysical Research Letters 31, L09311. http://dx.doi.org/ 10.1029/2004GL019718.

Xu, J.P., Wong, F.L., Kvitek, R., Smith, D., Paull, C.K., 2008. Sandwave migration in Monterey Submarine Canyon, Central California. Marine Geology 248, 193-212.

Xu, J.P., Swatzenski, P.W., Noble, M., Li, A.-C., 2010. Event-driven sediment flux in Hueneme and Mugu submarine canyons, Southern California. Marine Geology 269, 74-88.

$\mathrm{Xu}$, J.P., 2010. Normalized velocity profiles of field-measured turbidity currents. Geology 38, 563-566.

$\mathrm{Xu}$, J.P., 2011. Measuring currents in submarine canyons: technological and scientific progress in the past 30 years. Geosphere 7, 868-876.

Xu, J.P., Barry, J.P., Paull, C.K., 2013. Small-scale turbidity currents in a big submarine canyon. Geology 41, 143-146. http://dx.doi.org/10.1130/G33727.1.

Zeng, J.J., Lowe, D.R., Prior, D.B., Wiseman, W.J., Bornhold, B.D., 1991. Flow properties of turbidity currents in Bute Inlet, British Colombia. Sedimentology 38, 975-996.

Zeng, J.J., Lowe, D.R., 1997. Numerical simulation of turbidity current flow and sedimentation. 2. Results and geological applications. Sedimentology 44, 85-104.

\section{R E F E R E N C E S}

Amy, L.A., Talling, P.J., 2006. Anatomy of turbidites and linked debrites based on long distance $(120 \times 30 \mathrm{~km})$ bed correlation, Marnoso Arenacea Formation, Northern Apennines, Italy. Sedimentology 53, 161-212.

Bell, H.S., 1942. Some evidence regarding the kind and quantity of sediment transported by density currents. Transactions of the American Geophysical Union 67-73.

Cantero, M.I., Cantelli, A., Pirmez, C., Balachandar, S., Mohrig, D., Hickson, T.A., Yeh, T.-H., Naruse, H., Parker, G., 2012. Emplacement of massive turbidites linked to extinction of turbulence in turbidity currents. Nature Geoscience 5, 42-45.

Crookshanks, S., Gilbert, R., 2009. Sediment waves in a modern high-energy glacilacustrine environment. Sedimentology 56, 645-659.

Grover, N.C., Howard, C.L., 1938. The passage of turbid water through Lake Mead. Transactions of the American Society of Civil Engineers 103, 720.

Heezen, B.C., Drake, C.L., 1964. Grand Banks slump. AAPG Bulletin 48, 221-225.

Lambert, A., Kelts, K.R., Marshall, N.F., 1976. Measurements of density underflows from Walensee, Switzerland. Sedimentology 23, 87-105

Mitsuzawa, K., Iwase, R., Otsuka, R., Hirata, K., Mikada, H., 2004. Long-term deep current measurements by JAMSTEC cabled observatories. IEEE Journal of Oceanic Engineering 4, 2206-2210.

Savoye, B., Babonneau, N., Dennielou, B., Bez, M., 2009. Geological overview of the AngolaCongo margin, the Congo deep-sea fan and its submarine valleys. Deep-Sea Research Part II 56, 2169-2182

Sumner, E.J., Talling, P.J., Amy, L.A., Wynn, R.B., Stevenson, C., Frenz, M., 2012. Facies architecture of ancient and modern basin-plain turbidites: similarities and differences to existing models and implications for sediment gravity flow processes. Sedimentology. http://dx.doi.org/10.1111/j.1365-3091.2012.01329.x.

Wright, S., Parker, G., 2004. Density stratification effects in sand-bed rivers. Journal of Hydraulic Engineering 130, 783-795. 